Milica MIKECIN

UDK 821.163.42-97:003.349.1

Zagreb

milamikecin@yahoo.com
27-252.6

Izvorni znanstveni članak Primljen: 16. travnja 2019. Prihvaćen: 11. lipnja 2019.

\title{
APOKRIF USNUĆE BOGORODICE U HRVATSKOGLAGOLJSKOJ KNJIŽEVNOSTI (II). USPOREDNA JEZIKOSLOVNA I TEKSTOLOŠKA ANALIZA ZBORNIČKIH TEKSTOVA
}

\begin{abstract}
Više zbornika neliturgijskih tekstova hrvatske srednjovjekovne književnosti sadrži apokrif o Bogorodičinoj smrti i uznesenju. Dok je u jednima to prijepis prijevodne prerade grčkoga teksta Pseudo-Ivana apostola i evanđelista, koji pripada tzv. betlehemskoj predaji apokrifa (Vinodolski zbornik, 15. st. i Grškovićev zbornik, 16. st.), drugi sadrže prijepis prijevodne prerade latinskoga prijevoda grčkoga Pseudo-Melitonova teksta, koji pripada tzv. palminoj predaji (Fatevićev zbornik duhovnog štiva, 1617. i latinički zbornik Codex Varia Variorum 39, 17. st.). Usporednom jezikoslovnom i tekstološkom analizom najstarijega sačuvanog hrvatskoglagoljskog teksta betlehemske predaje iz Pazinskih fragmenata (14. st.) i Vinodolskoga zbornika u odnosu na grčki izvornik, zatim usporednom analizom teksta iz Vinodolskoga zbornika i njemu srodnoga teksta iz Grškovićeva zbornika te naposljetku usporednom analizom tekstova iz Fatevićeva zbornika i Codex Varia Variorum 39 utvrđuju se osobitosti jezika svih četiriju zborničkih tekstova na svim jezičnim razinama s obzirom na udio staroslavenskih jezičnih elemenata i elemenata narodnoga govornoga jezika. Na primjeru apokrifa o uznesenju Bogorodice u hrvatskoj srednjovjekovnoj glagoljičkoj i latiničkoj književnosti prati se povijesni razvoj jezika od hrvatskostaroslavenskoga preko starijega i mlađega hrvatsko-staroslavenskoga do hrvatskoga narodnoga jezika sa staroslavenskim elementima. Rad donosi i transliterirano izdanje tekstova iz Vinodolskoga zbornika i iz Grškovićeva zbornika.
\end{abstract}

Ključne riječi: apokrif o usnuću Bogorodice, Pazinski fragmenti, Vinodolski zbornik, Grškovićev zbornik, Fatevićev zbornik, Codex Varia Variorum, hrvatskoglagoljska književnost, hrvatskostaroslavenski jezik, hrvatsko-staroslavenski jezik, čakavski jezik, usporedna jezikoslovna i tekstološka analiza 


\section{UVOD}

Novozavjetni apokrif Usnuće Bogorodice nastao je vjerojatno u drugoj polovici 4. stoljeća. Izvorno je napisan na grčkom jeziku na području Sirije ili Palestine. Cjelokupna predaja apokrifa dijeli se u dvije glavne skupine koje se nazivaju palmina predaja i betlehemska predaja. Prva je nazvana tako zbog rajske palme koju anđeo Gabrijel donosi Mariji kada joj naviješta smrt i koja nakon njezine smrti svijetli pred njezinim odrom na sprovodu, a druga je dobila ime po tome što Marija prije smrti u bijegu pred židovskim vlastima iz Jeruzalema odlazi u Betlehem i zatim se opet vraća u Jeruzalem, gdje umire. Najstariji sačuvani grčki tekst palmine predaje, Transitus $R$, nastao je u 6 . stoljeću i osnova je za mlađi grčki tekst iz 7. stoljeća koji se pripisuje solunskomu nadbiskupu Ivanu Bogoslovu (Ivanu Solunskomu). Najstariji latinski prijevod s grčkoga, blizak Transitusu $R$, poznat je pod nazivom Transitus $A$, a mlađi latinski tekst, nastao krajem 5. stoljeća, takozvani Transitus $B$, prijevod je grčkoga izvornika koji se pripisuje Pseudo-Melitonu. Palmina se predaja na osnovi latinskoga prijevoda grčkoga Pseudo-Melitonova teksta proširila u zapadnoj Europi. Najstariji sačuvani grčki spis betlehemske predaje nastao je potkraj 5. ili početkom 6. stoljeća, a pripisuje se Pseudo-Ivanu apostolu i evanđelistu. Taj se tekst proširio na cijelom grčkom jezičnom prostoru te se zadržao samo na Istoku, postoji u velikom broju rukopisa i u prijevodima na razne jezike, pa tako i na staroslavenski. ${ }^{1}$

U hrvatskoj glagoljskoj književnosti sačuvani su prijepisi apokrifa koji pripadaju objema predajama. Jedni od njih u svojoj osnovi imaju grčke tekstove, a drugi njihove latinske prijevode. ${ }^{2}$ Tri su teksta prijepisi prijevoda ili

1 Prikaz povijesti obiju predaja apokrifa o usnuću Bogorodice vidi u MIKECIN 2018: 228232.

2 Na to je upozorila Biserka Grabar: »O Marijinoj smrti i njezinu uznesenju na nebo govori apokrif poznat općenito pod latinskim naslovom Transitus Mariae ili Dormitio Deiparae. Grčki original koji se širio u nekoliko verzija nastao je najkasnije do V. st. Na osnovu grčkog teksta nastala je latinska verzija Tranzita koja se pripisuje sardskom biskupu Melitonu. Najkasnije do XII st. preveden je taj apokrif s grčkoga na staroslavenski. U slavenskom svijetu širio se najčešće pod naslovom Uspenije Bogorodice. K nama je došao preko prevedene crkvenoslavenske matice. Najstariji i najbolje tradirani crkvenoslavenski tekst hrvatske redakcije sačuvan je, na žalost, samo fragmentarno u glagoljskim Pazinskim fragmentima iz XIV st. Potpuni tekst Tranzita nalazimo u 3 glagoljska zbornika iz XV-XVII st. i u latiničkom dubrovačkom zborniku legendi što ga je izdao Karásek. Ovaj posljednji tekst kao i glagoljski tekst u Fatevićevu zborniku iz XVII st. zapadnog su, vjerojatno, latinskog porijekla« (GRABAR 1970: 22). 
prijevodnih obrada teksta Pseudo-Ivana apostola u okviru betlehemske predaje: 1. Pazinski fragmenti (u daljnjem tekstu: FgTrans), 90d-e-f s početka 14. stoljeća, ${ }^{3}$ 2. tekst iz Vinodolskoga zbornika (u daljnjem tekstu: CVinod), ff. $48 \mathrm{r}^{\mathrm{a}}-49 \mathrm{v}^{\mathrm{b}}$ iz prve polovice 15. stoljeća, ${ }^{4} 3$. tekst iz Grškovićeva zbornika (u daljnjem tekstu CGrš), ff. 167v-171r iz druge polovice 16. stoljeća. ${ }^{5}$ Dva su teksta prijepisi prijevodnih prerada teksta Pseudo-Melitona u okviru palmine predaje: 1. tekst iz Fatevićeva zbornika duhovnog štiva (u daljnjem tekstu CFat), ff. 1r-1v i 18v-22v, iz 1617. godine, ${ }^{6}$ 2. tekst iz Codex Varia Variorum 39 (u daljnjem tekstu: CVar). ${ }^{7}$

Tekst apokrifa o Bogorodičinu usnuću iz FgTrans izdvaja se u prvoj skupini od drugih tekstova po tome što je on jedini hrvatskostaroslavenski prijepis staroslavenskoga prijevoda grčkoga teksta Ivana apostola i evanđelista dok su ostala dva teksta hrvatsko-staroslavenski prijepisi kasnije prerade prijevoda istoga grčkog teksta. ${ }^{8}$ Tekst iz FgTrans je uz neke tekstove ruske i srpske redakcije staroslavenskoga jezika jedan od nastarijih slavenskih tekstova toga apokrifa uopće. ${ }^{9}$ Prijevod s grčkoga jezika sadržan u FgTrans potpuno je doslovan, a posljedica toga je i posebnost jezika FgTrans, koji ima sve odlike najstarijega hrvatskostaroslavenskoga jezika vrlo bliskoga staroslavenskomu jeziku. ${ }^{10}$ Zbornički tekstovi apokrifa pisani su hrvatsko-staroslavenskim jezikom, a udio čakavskoga jezika znatniji je u mlađem tekstu iz CGrš, a manji je u starijem tekstu iz CVinod. ${ }^{11}$ Tekst apokrifa o usnuću Bogorodice iz CFat

3 Tekst iz FgTrans izdan je i jezično analiziran u MIHALJEVIĆ; VINCE 2012.

4 Tekst iz CVinod transkribiran je u STROHAL 1917: 36-39; ŠTEFANIĆ i sur. 1969: 149-153 i DÜRRIGL 2013: 135-138. Skraćenu verziju apokrifa na suvremenom hrvatskom jeziku donosi DAMJANOVIĆ 1998: 35-37. Transliterirano izdanje toga teksta nalazi se u Prilogu ovoga rada.

5 Transliterirano izdanje teksta iz CGrš nalazi se u prilogu ovoga rada.

6 Taj je tekst izdan u okviru izdanja cjelokupnoga CFat, koje je priredila G. Franov-Živković. Vidi FZ 2016.

7 Izdanje i opis rukopisa CVar nalazi se u KARÁSEK 1913: 3-15 [pretisak 1996].

8 Nazivi staroslavenski, hrvatskostaroslavenski i hrvatsko-staroslavenski jezik upotrebljavaju se prema podjeli jezičnih idioma kod Stjepana Damjanovića. Vidi npr. DAMJANOVIĆ 2000: 29. U paleoslavistici postoje i drugi nazivi: starocrkvenoslavenski, hrvatski crkvenoslavenski i hrvatsko-crkvenoslavenski amalgam. Vidi npr. HCSL 2014: 18-19.

9 Usp. HERCIGONJA 1975: 110-112. Jezikoslovnu usporedbu najstarijih tekstova hrvatske, srpske i ruske redakcije vidi u MIKECIN 2018: 255-263.

${ }^{10}$ Pregled dosadašnjih istraživanja teksta iz FgTrans s literaturom nalazi se u MIKECIN 2018: 239-240.

${ }^{11}$ O jeziku i tekstovima CVinod vidi ŠTEFANIĆ 1970: 5-10; MILČETIĆ 1911: 214; STROHAL 1916: 5; HERCIGONJA 1983: 345; DAMJANOVIĆ 2009: 357; VUČKOVIĆ 2017: 
nalazi se u njegovu prvom i starijem dijelu, a prepisan je početkom XVII. stoljeća iz starijega slavenskoga predloška. ${ }^{12}$ Codex Varia Variorum 39, po novom kataloškom broju 914, koji se običava nazivati još i Dubrovačkim legendama jer je pohranjen u Biblioteci franjevačkog samostana Male braće u Dubrovniku, u svojem prvom dijelu, koji je prepisan u XVII. stoljeću, među raznim tekstovima hrvatske apokrifne književnosti sadrži i latinični tekst apokrifa o usnuću Bogorodice u obliku propovijedi o »uzvišenju prečiste svete djeve Marije $\ll .^{13}$ Tekst je najvjerojatnije preveden s talijanskoga jezika iz neke hagiografsko-legendarne zbirke prevedene s latinskoga, ali točan predložak nije utvrđen. Poznato je da je jedan od izvora za tekstove CVar talijanski prijevod latinske zbirke Legenda aurea, koju je u drugoj polovici XIII. stoljeća sastavio genovski biskup Jakov Voraginski (1228. - 1298.). ${ }^{14}$

45-49. Pregled dosadašnjih istraživanja tekstova iz CVinod s literaturom vidi u VUČKOVIĆ 2017: 49-50. O jeziku i tekstovima CGrš vidi ŠTEFANIĆ 1970: 51-52; NAZOR 1978: 46; DAMJANOVIĆ 1995: 68; DAMJANOVIĆ 2009: 358, 395-399; HERCIGONJA 2004: 241; HERCIGONJA 1983: 347; VELČIĆ 2002: 244; REINHART 2010: 670. Tekstovi iz CGrš dosad nisu bili dovoljno proučavani i najčešće su služili samo kao dopuna u nekim transkripcijama tekstova iz drugih zbornika (STROHAL 1917; ŠTEFANIĆ 1969; DÜRRIGL 2017), jer prednost pri izdanju tekstova koji sadrže verzije istoga spisa najčešće imaju stariji zbornici, bolje sačuvani ili oni u kojima se nalazi duža verzija teksta. Transliterirano izdanje jednoga mirakula iz CGrš priredio je REINHART 2010: 669-686.

12 Jezik i tekstove CFat proučavali su MILČETIĆ 1911: 340-344; STROHAL 1915: 173-176; ŠTEFANIĆ 1970: 57-60; PETROVIĆ 1998: 143; TURKALJ 2008: 579-593; RADOŠEVIĆ: 2012: 101-210; FRANOV-ŽIVKOVIĆ 2016: 212-220; VIGATO 2016: 29-39; GALIĆ 2017: 199-208; DÜRRIGL 2017: 23-43; GALIĆ 2018: 99-169.

${ }^{13}$ CVar izdao je češki slavist Josef Karásek 1913. u Pragu pod naslovom Ragusäische Legenden, a pretisak toga izdanja objavljen je u Zagrebu 1996. pod naslovom Dubrovačke legende (KARÁSEK 1913). Vidi BRATULIĆ 1996: 196-197; ŠABIĆ 2010: 286-287. O CVar pisali su: KOMBOL 1945: 36; HERCIGONJA 1975: 291-302; PETROVIĆ 1984: 188, a o njima se govori i u dvjema antologijama u koje su uvršteni i tekstovi iz zbornika: BADURINA-STIPČEVIĆ 2013: 19-20 (Život sv. Marije Egipatske 132-139, Život sv. Eufrosine 140-151, Život sv. Barlaama i Jozafata 187-259) i DÜRRIGL 2013: 60, 65 (Apokrifo smrti Blažene Djevice Marije 135-138). U ŠTEFANIĆ i sur. 1969: 295-303 nalazi se transkripcija teksta o Barlaamu i Jozafatu.

${ }^{14}$ Kao predložak nekim tekstovima iz CVar poslužili su tekstovi iz četvrtoga dijela talijanskoga prijevoda hagiografske zbirke Vitae Patrum, koji je oko 1330. godine sačinio dominikanski redovnik iz Pise Domenico Cavalca (1270. - 1342.) i koji je pod naslovom Vite de' santi Padri prvi put tiskan 1474. godine u Ferrari. Usp. BRATULIĆ 1996: 198; PETROVIĆ 1984: 194: »Talijanski hagiografsko-legendarni tekstovi ulazili su u hrvatsku književnost možda već iz sjevernoitalskih tekstova 13. stoljeća Bonvesina della Rive, ali su glavni poticaj hrvatskom prihvaćanju talijanskih tekstova dale franjevačka književnost 14. stoljeća i dominikan- 
Hrvatski tekstovi betlehemske predaje (u daljnjem tekstu BP) i palmine predaje (u daljnjem tekstu PP) apokrifa pokazuju sadržajne sličnosti i razlike. Prema BP Mariji smrt naviješta arkanđeo Gabrijel došavši na Isusov grob, a prema PP bezimeni anđeo došavši na Sionsku goru i ostavivši Mariji svijetlu mladicu palme iz raja. ${ }^{15}$ Prema BP Marija prije smrti moli Isusa da joj pošalje apostola Ivana i sve druge apostole i da ju uzme k sebi na nebo te pritom kaže kako joj Židovi prijete da će spaliti njezino tijelo kada premine, a prema PP tim istim molbama pridodaje i molbu da u času smrti ne vidi strašnoga duha. Nakon što Marija prema BP ode iz Jeruzalema, apostoli na čudesan način na oblacima dolaze s raznih strana svijeta u Marijinu kuću u Betlehemu, a prema PP oni dolaze u kuću u Jeruzalemu, koju Marija zajedno s apostolima ne napušta sve do svoje smrti. Nevjerni Židovi u BP nastoje spaliti Marijino tijelo i apostole u kući u Betlehemu, pa ih zato Duh Sveti na oblacima vraća u Jeruzalem, dočim u PP Židovi nastoje ubiti apostole i spaliti Marijino tijelo za vrijeme pogrebne povorke. U BP Marija prije svoje smrti čudesno iscjeljuje slijepe i hrome u kući u Betlehemu, a uglednoga Židova Jefoniju iscjeljuje tijekom pogreba, dočim u PP Marija iscjeljuje jedino Jefoniju, koji zatim od apostola Ivana uzima palmu tako da se iscjeljuju i svi drugi Židovi koji su povjerovali u Isusa Krista i Mariju. U objema predajama Marija umire i Isus prima njezinu dušu u svoje ruke. Nakon toga su prema BP apostoli s Marijinim tijelom na odru preneseni Duhom Svetim na nebo, a prema PP Isus dolazi trećega dana nakon Marijine smrti na njezin grob u Jozafatskoj dolini. U BP Isus sjedinjuje njezinu dušu i tijelo $u$ raju, te je ona time na nebo uznesena dušom i tijelom, a u PP Marijina duša iz raja silazi u grob i ulazi u tijelo, Isus ondje uskrisuje Mariju i uznosi ju dušom i tijelom na nebo.

\section{USPOREDNA JEZIKOSLOVNA I TEKSTOLOŠKA ANALIZA APOKRIFA USNUĆE BOGORODICE IZ PAZINSKIH FRAGMENATA I VINODOLSKOGA ZBORNIKA}

ska literatura Jacopa Passavantija i talijanskih volgarizzamenata visoke literarne vrijednosti Domenica Cavalce, te druga djela talijanske književnosti zrelog i poznog srednjega vijeka.«

${ }^{15}$ Palma se spominje na mnogim mjestima u Bibliji, a u kršćanstvu postaje simbol pravde, svetosti i uskrsnuća. Prikaz palme vrlo je čest i u židovskim hramovima i u kršćanskim crkvama, pravednik Božji uspoređuje se s palmom (Ps 92,13), a palma u rukama mučenika znak je pobjede nad smrću i rajskoga života. Pretpostavlja se da je rajsko stablo života bilo palma. Palmin plod čuva tijelo umrloga od propadanja dok ne prijeđe u nebeski život. 


\subsection{Jezikoslovna analiza}

Usporedna jezikoslovna i tekstološka analiza tekstova iz FgTrans i CVinod ograničena je na dio apokrifa koji je sačuvan u obama rukopisima. ${ }^{16}$ Dio teksta iz CVinod koji se odnosi na FgTrans 1a-1c, a počinje od mjesta 48rb16, potpuno je prerađen i sadrži samo pojedine riječi koje se nalaze i u FgTrans te pokazuje samo opće sadržajne sličnosti s njim. Dijelovi teksta FgTrans 1d-2d i 3c-d sadrže neprekinut tekst apokrifa, odnosno veće komade teksta bez lakuna. Na tekst FgTrans $1 \mathrm{~d}-2 \mathrm{~d}$ odnosi se tekst CVinod $48 \mathrm{r}^{\mathrm{b}} 34-48 \mathrm{v}^{\mathrm{b}} 3$, a na tekst FgTrans $3 \mathrm{c}-\mathrm{d}$ odnosi se tekst CVinod $49 \mathrm{r}^{\mathrm{b}} 12-49 \mathrm{v}^{\mathrm{a}} 7$. Fragmenti $3 \mathrm{a}-\mathrm{b}$ sadrže dijelove s mnogo lakuna, ali u dijelovima koji imaju neprekinut tekst može se zamijetiti mnogo više sličnosti s tekstom iz CVinod, ali još uvijek sa znatnim preinakama. U prikazu teksta iz FgTrans neukošenim slovima označeni su oni dijelovi koji su u CVinod preneseni, a potcrtani i ukošeni su dijelovi koji su nedoslovno preuzeti, odnosno djelomično preinačeni ili premješteni, a sav ostali ukošeni tekst nije sadržan u CVinod, koji obratno sadrži i neke dijelove kojih nema u FgTrans. ${ }^{17}$

FgTrans

(1a) ... sьžsgut' têlo moe · I otveĉavb rêhb ei · ne imat' vidêti istlêniê prêpodobnoe i čbstnoe tvoe têlo · Otveĉav'ši $[\check{z}]$ e s(ve)taê mariê reče $k b$ mnê $\cdot$ prine-

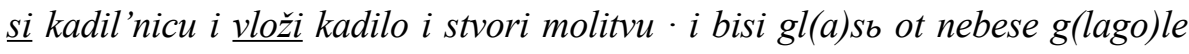
am(e)nb $\cdot$ I sliša ... (1b) ...go $\cdot$ Ti simune petre iz' rima $\cdot$ pavlb ot tiveriona. toma ot in'die vbnutr'n'nêišihb · êkovb ot erusolima · an'drêi bratb petrovb pilipb luka $\underline{i}$ simunb kananêi $\cdot$ počivše $i$ vstavbše iz' grobs svoihb d(u)hom s(ve)tim'k nim'že reče ne mnite êko vskrêšenie es... (1c) ... [n]a oblacêhb. obrêtom'se s'petrom' i tako $\mathrm{s}(\mathrm{ve}) \mathrm{tim} \mathrm{d}(\mathrm{u}) \mathrm{hom}$ ' vkupb vsi pridom'na mêsto - Î prišbdbše kb materi g(ospod) a b(og)a našego · približ ’šu že se vrêmeni . poklon'še se rêhomb ne boi se ni skr'bi $\cdot g(o s p o d)_{b} b(o g)_{b}$ roždbi se is tebe izvodit'te iz'mira sego sb slavoû $i$ vzradovav'š $[i]$... (1d) ...oe prisêcenie · ne utai bo mene roždbi se iz' mene ' $g\left(\right.$ ospod) b našb is $(u) h(r b s t) b \quad b(o g)_{b}$ vsêm'. Otveĉav že petrb reče kb ap (usto)lom' k kbždo k nemuže s(ve)ti d(u)hb vbzvêsti - $i$ zapovêdê n(a)mb · vbzvêstête materi g(ospod)a b(og)a našego is(u)h(rbst)a . Otveĉav že azb ivanb $\underline{r e ̂ h b}$. azb egda vshož- (2a) -dahb vb s(ve)ti gradı $\underline{i} \underline{\text { oltar}}$ ' službu stvoriti v' epesê · d(u)hь g(lago)la mi · êko približi se vrême prêstavle-

${ }^{16}$ Cjelovita jezikoslovna analiza FgTrans nalazi se u MIHALJEVIĆ; VINCE 2012: 17-116.

${ }^{17}$ Tekst iz FgTrans navodi se i označava prema izdanju MIHALJEVIĆ; VINCE 2012: 132 138. Mjesta iz CVinod navode se i označavaju prema izdanju u prilogu ovoga rada. 
niûu materê g(ospod)a $b(\mathrm{og})$ a tvoego $\cdot$ hodi vb vitleom' na cêlovanie ee $\cdot i$ oblak'svêtl'vshiti me i v'dv'rehb idêže ležiši postavi me $I$ petrb reče $\cdot \underline{a z b} \mathrm{v}$ rimê živi · $k$ 'ûtroni slišahь glasb s(ve)[t]im' $\underline{d(u) h o m}$ 'g(lago)luĉb $\underline{k}$ ' mnê $\cdot e ̂ k o$ materi g(ospod)a tvoego približ'šu se vrêmeni ' prêstavlena imat' biti hodi v' vitlêom' na cêlovanie ee $i$ se oblakb svêtl'vshiti me 'I vidêhb pročee ap(usto)li na oblacê greducee $k b$ mnê · i gl(a)sb g(lago)le kb mnê · vsi idête v' vitlêom' - Otveĉav že pavlb reče · i azb v gradê otstoeĉi ot rima ne malom' rastoênim' ži- (2b) - vi tiverionb stranê naricaemêi · slišahb duhb s(ve)ti g(lago)lûco kb mnê · Mati g(ospod) a tvoego [os]tavlaûci mirb sa na nebeskaê prêstavleniem' tečenie tvorit' · na idi v vitlêom' na cêlovanie ee · i se oblakb svêt [l'v]shiti me i posta[vi me] idê̌ze $i$ vi $\cdot$ Otveĉav [že] toma reče $\cdot i$ azb in'diiskuû stranu prêšbdb [prop]ovêdi h(rbsto)voû bl(a)godêtiû utvrbždae · i sinb sestri c(êsa)rici imenem' lav'danusb ' mnoû hoteĉim' znamenati se v polači vnezapu d(u)hь $\mathrm{s}(\mathrm{ve}) \mathrm{ti} \mathrm{g}$ (lagl)la k' mnê · I ti toma idi v' vitlêom' na cêlovanie matere g(ospod)a tvoego êko prêstavlenie na nebesa tvorit' $\cdot i$ oblak'svêtlb vshiti me · i postavi me pri vasь - Otveĉav že markb reče (2c) azb po kanonu tretie godini vb alek'sandrıscêem' gradê $\underline{m(o) l(i t) v u}$ tvorah[ь e]gda me s(ve)ti duhь vshiti

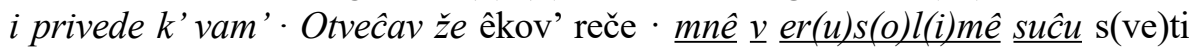
$\mathrm{d}(\mathrm{u}) \mathrm{h}_{\mathrm{b}} \cdot$ povelê mi g[la]gole $\cdot$ budi vb vit[leom]ê $\cdot \hat{e} k o$ mati g(ospod) a t [v]oego prêstavlenie tvorit' $i$ se oblakb svê[tlb] vshiti me i postavi me prêd vami . Otveĉav že matiê reče $\cdot i$ azb proslavihb $i$ slavlû b(og)a êko suĉu mi v mori $i$ valaûcu se $i$ v'zmuĉšsu se vl'nami · vnezapu oblakb svêtlb osênb vl'nenie mutnoe prêstavi na tihost' mene že vshiĉb postavi prêdb vami $\cdot$ Otveĉav'še že takožde i ošbdbšei prbvoe · povêdêse kako pridu I bartolo- (2d) -mêi reče - $\underline{a z b} v$ tivoidê bêhь propovêdae sl(o)vo $i$ se d(u)hь s(ve)ti g(lago)la kb mnê - mati g(ospod) a vašego prêstavlenie tvorit' · idi vb vitlêom' [na cêllo[vanie e]e · i se oblakb svêt[lb] vshich me privede se $k$ vam' Si vsi povêdêše s(ve)ti ap(usto)li kako pridu $k^{\prime}$ b(ogorodi)ci $\cdot i$ kotoroû kazniû $i$ vz[dê]vši rucê na nebo pomoli se g(lago)lîci $\cdot$ klanâ̂ se i hvalû $i$ slavlû mnogohval'noe ime tvoe $g($ ospod) $i \cdot$ êko prizrêlb esi na smêrenie rabi tvoee $g(o s p o d) i \cdot i$ stvoril' mi esi velikoti silni · i blažet' me vsi rodi · I po molit'vê reče ap(usto)lom' · vložite kadilo i stvorite m(o)l(i)tvu $i$ pomol'šem se imb gromb bisi s nebese $\cdot i$ pride glasb straš[bnb] ... (3a) ... i mariê božiê mati vidê slavu na nem' eeže usta $\check{c}$ (lovếc) ska ne mogut' isp(o)vêdêti ni ... G(ospod)b že k nei reče · se ot [n]ine budet' têlo tvoe čbstnoe prêloženo na rai ... a s(ve)taê tvoê d(u)ša na nebes[a] v skroviĉa $o(t) \check{c} a \cdot \mathrm{v}$ svêtlostb idêže estb mirb i veselie $\cdot$ Otveĉavši že s(ve)taê reče $k$ nemu ' naloži de[sn]icu svô̂ i bl(agoslo)vi me ... g(ospod)b $\check{c}[b s] t n u$ [desnic]u svoû bl(agoslo)vi û [· on]a že [drıž]ecci [lo]bizaše čs[s]tnuû [de]- 


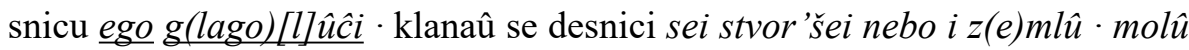
mnogohval'noe ime tvoe g(ospod)i b(ož)e c(êsa)ru vsêhb v(ê)kb inočedi sine $o(t b) \check{c}$ primi rabi[nû] tvồ izvoliv se (3b) roditi iz mene smêrenie spaseniê radi č(lovế) [s]kago za neizrečen'noe tvoe smotrenie vsbkomu [č(lovê)ku pr]i-

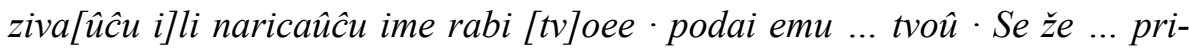

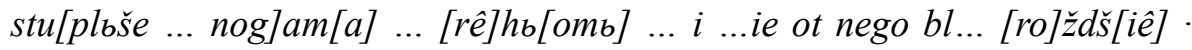
vb[s]emu miru · Pom[o]l'ši že se mati g(ospod)na · reče v svoei molitvê sice - b(o)že iže esi blagostiû tvoê̂u poslalb inočedi sinb tvoi vseliti se v smêrenoe moe têlo · $i$ roditi se ot mene · pomilui vbsb mirb tvoi i vs'ku d(u)šsu naricâ̂cu ime tvoe - I paki pomol'si se reče $\cdot h(r b s t)$ e c(êsa)ru neb- (3c) -eski sine b(og)a živago ' primi vs'kogo čclovê)ka prizivaûcago ime tvoe $\mathrm{s}(\mathrm{ve})[\mathrm{toe}] \mathrm{i}$ blagoe da pr[oslavle]na bud[et'] roišiê te . [Î] paki pomol'ši se reče ... možeši na nebe[si] ... se molenie pr[imi] ... s(ve)toe ... o .... i [dêže] ... i ... [pros]lavi slaveĉe[e] ... imenem' ' priemle ... na vs 'ko pr[inoše]nie i vsbku molitvu i obêt' $\cdot$ sice ei pomol'ši se - G(ospod)b že k nei reče veseli se i da raduet' se sr(bd)ce tvoe · vs'ka bo bl(a)godêt' $\cdot i$ vsbki darb danb ti bisi $\cdot o(t)$ cem 'nebeskim' $\cdot i$ mnoû - $i$ s(ve)tim'duhom' $i$ vs'ka duša êže te prizivaets · ne imatb se postidêti · na obrêcet' milostb i utêhu i zastuplenie i dr'znovenie · $i \mathrm{v} n$ - (3d) -inêšni $\underline{v}(\hat{e}) k b$ i v buduci $\cdot$ prêdb oce [m 'mo]imb nebeskim' ' Obraĉ že se g(ospod)ь k petru reče - prispê vrême načni pênie · petr [u že] načenšu pênie · vse sili nebeskie otpêše - al(elu)ê · I t'gda lice matere gospodne prosv'tê se pače svêta · i vzved[ši] se svoeû rukoû bl(agoslo)vi kogoždo ap(usto)la $\cdot i$ vzdahom' vsi slavu b(og)u $\cdot$ I g(ospod)u prostrbvšu rucê priet' s(ve)[tuû] i nepo[ročnu] $\mathrm{u}$ ee $\mathrm{d}[\mathrm{uš}] \mathrm{u} \cdot \underline{i s h[o z ̌-}$ den]iem' s(ve)[t]ie duš[e ee isp]l'ni se vone blage [i n]eizre[č]ena svêta [mê]sto $\cdot i$ se glasb uslišanb bistb s nebese g(lago)le · blaženaê $\cdot$ I tek'še petrb - i pavlb · i toma 'i proči ap(usto)li · ohopihom' čbstnê ee nozê · da se bim osvetili $\cdot$ i mi sami oba na desete $\cdot \check{c} b[s]$ tn [oe] ...

Više od dvije trećine teksta FgTrans uopće nije preneseno u CVinod, a preneseni dio znatno je prerađen i izmijenjen. Prikazani tekst FgTrans zorno pokazuje u kojoj je mjeri primijenjen postupak skraćivanja i izostavljanja u prerađenom tekstu iz CVinod. Najmanji su ispusti i preinake, premda još uvijek krupni, u fragmentima $3 \mathrm{a}-\mathrm{d}$, znatno su veći u fragmentima $2 \mathrm{a}-\mathrm{d}$, a sudeći po usporedivom sačuvanom tekstu najveći su u fragmentima 1a-d.

Pet je glavnih postupaka preinačujućeg skraćivanja i sažimanja:

1. potpuno izostavljanje cijelih rečenica, dijelova rečenica i riječi, npr. Otveĉav že êkov' reče · mnê v er(u)s(o)l(i)mê suĉu s(ve)ti d(u)hb · povelê mi g[la]gole ' budi vb vit[leom] ê êko mati g(ospod) a t[v]oego prêstavlenie tvorit' - i se oblakb svê[tlb] vshiti me i postavi me prêd vami - Otveĉav že matiê reče . 


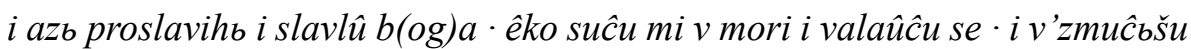
se vl'nami · vnezapu oblakb svêtlb osên b vl'nenie mutnoe prêstavi na tihost'. mene že vshiçb postavi prêdb vami $\cdot$ Otveĉav'še že takožde i ošbdbšei prbvoe. povêdêse kako pridu - I bartolomêi reče $\cdot a z b$ v tivoidê bêhb propovêdae sl(o)vo (FgTrans 2c-d) : êk(o)v'r(e)če ê bih'v er(u)s(oli)mê i d(u)hb s(ve)ti vshiti me i postavi me simo A bar'tolomêi r(e)če ê bih' propovêdae sl(o)vo b(o)žie $\left(C \operatorname{Vinod} 48 \mathrm{v}^{\mathrm{a}}\right)$;

2. izostavljanje cijelih rečenica, a češće dijelova rečenica i riječi uz spajanje onoga što prethodi i slijedi u jedinstvenu rečenicu, npr. $G($ ospod) $b$ že k nei reče veseli se i da raduet'se $\mathrm{sr}(\mathrm{b} d)$ ce tvoe · vs'ka bo bl(a)godêt' $\cdot i$ vsbki darb danb ti bisi $\cdot o(t)$ cem 'nebeskim' $i$ mnoû · i s(ve)tim'duhom' $i$ i vs 'ka duša êže te prizivaetb ' ne imatb se postidêti $\cdot$ na obrêcet' milostb $i$ utêhu i zastuplenie $i$ dr'znovenie · $i$ v ninêšni v(ê) kb i v buduĉi (FgTrans 3c) : A g(ospodi)nb b(og)b - r(e)če ei gospoe b(ogo)r(odi)ce vesel'se da raduet'se sr'ce tvoe v t(e)bi vs(a)ka d(u)ša ka priziva ime čisto ne more poginuti v v(ê)ki (CVinod 49rb),

3. izostavljanje uz premještanje postojećega teksta ili dodavanje novoga teksta kojega nema u FgTrans, npr. hodi vb vitleom 'na cêlovanie ee · i oblak' svêtl' vshiti me i v'dv'rehb idêže ležiši postavi me I petrb reče · azb v rimê živi $\cdot k$ ' ûtrbni slišahb glasb (FgTrans 2a) : poi v'vit'lêomb na pozdrav'lenie - gospoino m(a)t(e)re g(ospod)a $n(a) \check{s}(e) g o$ is $(u) h(r b s t) a \cdot \hat{e} p(e) t(a) r b v$ rimê bihi ûtr'ne poslušae (CVinod 48va);

4. sažimanje ili zamjenjivanje opsežnijega teksta sažetijim tekstom, pri čem se koriste odgovarajući dijelovi teksta ili pojedine riječi i izrazi koji se nalaze u FgTrans i od njih se oblikuje novi tekst sličnoga sadržaja, npr. Otveĉav [že] toma reče · $i$ azb in'diiskuû stranu prêšbdb [prop]ovêdi h(rbsto)voû bl(a)godêtiû utvrbždae · i sinb sestri c(êsa)- rici imenem'lav'danusb · mnoû hoteĉim' znamenati se v polači vnezapu d(u)hb s(ve)ti g(lagl)la k' mnê · I ti toma idi v' vitlêom' na cêlovanie matere g(ospod) a tvoego êko prêstavlenie na nebesa tvorit' ' i oblak' svêtlb vshiti me i postavi me pri vasb (FgTrans $2 \mathrm{~b})$ : toma r(e)če bih'v in'dii u al'vana kup'ca v polači i d(u)hb s(ve)ti vze me i postavi me · posredê v(a)sb simo $\left(\right.$ CVinod $\left.48 \mathrm{v}^{\mathrm{a}}\right)$;

5. oblikovanje novoga teksta od pojedinih riječi i izraza koji se uzimaju iz starijega predloška i premještaju s mjesta na kojem se nalaze u njemu na drugo i prilično udaljeno mjesto. Primjerice rečenica pr'nesête mi kadil'nicu $i$ $d r$ 'žeĉi kadilnicu (CVinod 48ra) sastavljena je od dvaju izraza koji su u prvobitnome slavenskom tekstu odvojeni i nalaze se u dijelu koji prethodi mjestu na koje su preuzeti. Daljnji su primjeri premještenih dijelova teksta: stvori molitvu (FgTrans 1a) : stvoriti m(o)l(i)tvu (CVinod 48ra $)$; glasb uslišanb bistb s 
nebese (FgTrans 3d) : gl(a)se sliše s n(e)b(e)sb (CVinod 48r $\left.{ }^{\mathrm{b}}\right)$; pilips luka i simuns kananêi (FgTrans 1b) : filip'ap (usto)lb i luka i simun 'i kananêi (CVinod $\left.48 \mathrm{v}^{\mathrm{a}}\right)$; približi se vrême (FgTrans 1c) : približi se vr(ê)me (CVinod $\left.49 \mathrm{r}^{\mathrm{b}}\right)$ itd.

Samo mjestimice pojavljuju se izrazi i dijelovi rečenica koji se podudaraju s onima iz FgTrans: vb alek'sandrbscêem' gradê (FgTrans 2c) : v leksan'dr'skom' gradu (CVinod 48va); bêhb propovêdae sl(o)vo (FgTrans 2d)

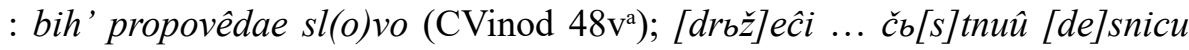
(FgTrans 3a) : držeĉi č(a)s 'tnuû desnicu (CVinod 49rb); I t'gda lice matere gospodne prosv'tê se (FgTrans 3d) : A tada se lice m(a)t(e)re g(ospod)ne prosvêti (CVinod $49 \mathrm{r}^{\mathrm{b}}$ ) itd. Ima i onih mjesta koja nisu doslovno preuzeta, ali iz kojih je nedvojbeno vidljivo da postoji daleka povezanost obaju tekstova: $k$ ' ûtrbni slišahb glasb (FgTrans 2a) : ûtr'ne poslušae (CVinod 48va); načni pênie (FgTrans 3d) : počni pês(nb) pêti (CVinod 49rb); oblakb svêtl [b] (FgTrans 2d) : obl(a)ka svitla (CVinod 49va); isp]l'ni se vone blage (FgTrans $3 \mathrm{~d}):$ se ... napl'ni bl(a)ge vone (CVinod 49a) itd.

Primjetno je da su mjesta koja u FgTrans odstupaju od grčkoga izvornika kao posljedica pogrešnoga shvaćanja, odnosno pogreške u prevođenju ili prepisivanju, u CVinod, kao i kasnije u CGrš, redovito skraćena ili izo-

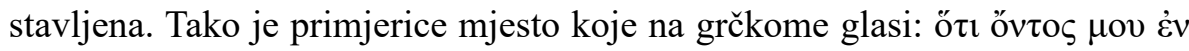

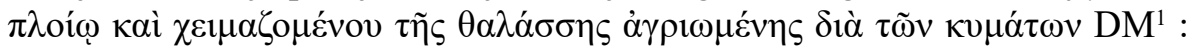

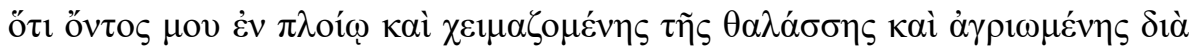

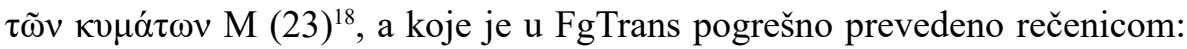
êko suĉu mi v mori i valaûcu se i v'zmuĉš̌s se vl'nami (2c), u CVinod izostavljeno, tj. uopće se ne spominje apostol Matej, niti se navodi njegov govor o tome kako je plovio nošen olujnim morskim valovima kada ga je Duh Sveti uzeo i odnio k Bogorodici. U CGrš na tome mjestu Matej kaže samo da je bio na moru, ali uopće ne spominje oluju: A s(ve)ti matii reče ê bihi na mori a duh sveti i postavi me posredi vas (CGrš 169r). Jednako tako CVinod i CGrš nemaju prijevod grčke rečenice: cĩ

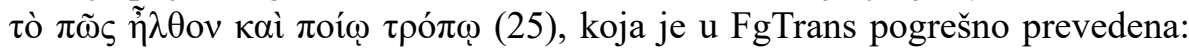
povêdêse s(ve)ti ap(usto)li kako pridu k'b(ogorodi)ci i kotoroû kazniû (2d).

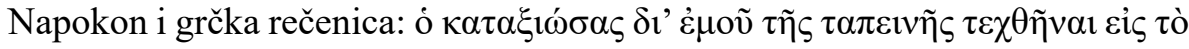

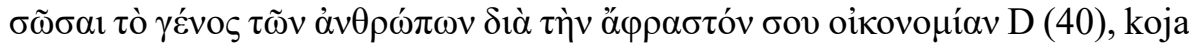
je u FgTrans pogrešno prevedena na sljedeći način: izvoliv se roditi iz mene

${ }^{18}$ Mjesta iz grčkoga izvornika navode se prema izdanjima TISCHENDORF 1866: 95-112 i BERGER 1805: 629-663, a označavaju se prema raščlambi poglavlja u Tischendorfovu izdanju. 
smêrenie spaseniê radi č(lovêč) [s] kago za neizrečen 'noe tvoe smotrenie (3b), ispuštena je u CVinod i CGrš (v. MIKECIN 2018: 245).

Dok u FgTrans svi apostoli koji su došli k Mariji na Petrov (FgTrans), tj. Pavlov (CVinod) zahtjev govore Mariji gdje su bili i što su činili kada ih je Duh Sveti uzeo i na oblaku odnio k njoj, u zborničkim tekstovima CVinod i CGrš većina apostola samo kazuje mjesto odakle su došli, a samo Petar, Bartolomej i Marko kazuju i što su tada činili.

Uočljive su i neke pogreške u prijepisu. Ime simunb kananêi (FgTrans 1b) pogrešno se prenosi kao da je riječ o dvama odvojenim imenima: simun' $i$ kananêi (CVinod 48v') / simun i ananiê (CGrš 169r). U FgTrans ime lav'danusb, koje u CVinod i CGrš postaje al'van' / alvan, shvaća se kao ime nekoga trgovca: u al'vana kup'ca (CVinod 48va) / u alvana kupca (CGrš 169r), a to je prema grčkome izvorniku zapravo ime nećaka indijskoga kralja.

\subsubsection{Fonologija i grafija}

U CVinod znak za poluglas u slabome položaju bilježi se štapićem i apostrofom ili je izgubljen. U odnosu na FgTrans mnogo je češća upotreba apostrofa, a rjeđa upotreba štapića. Štapić dolazi isključivo na kraju riječi, premda i u tome položaju rjeđe nego apostrof. Unutar riječi upotrebljava se samo apostrof, a štapić se više uopće ne pojavljuje, za razliku od FgTrans, u kojem je to veoma česta pojava. Sve je više primjera u kojima nema nikakva znaka za poluglas na mjestu nekadašnjeg slaboga jera: vsi (48ra $)$ i drugdje, množstvo $\left(48 \mathrm{v}^{\mathrm{b}}\right)$, mnogo $\left(48 \mathrm{v}^{\mathrm{b}}\right)$ i drugdje, vse $\left(49 \mathrm{r}^{\mathrm{a}}\right)$ i drugdje, mni $\left(49 \mathrm{r}^{\mathrm{a}}\right)$, desnicu $\left(49 \mathrm{r}^{\mathrm{b}}\right)$, neporočnu $\left(49 \mathrm{r}^{\mathrm{b}}\right), \check{c}(a)$ stno $\left(49 \mathrm{v}^{\mathrm{a}}\right)$ itd.

Zabilježeni su, međutim, i slučajevi u kojima se apostrof bilježi na mjestima na kojima poluglasa nije bilo, a nema ga ni u FgTrans: $s^{\prime}[v]$ oga $\left(48 \mathrm{r}^{\mathrm{a}}\right)$, $s^{\prime}$ vomu $\left(48 \mathrm{r}^{\mathrm{b}}\right)$. Apostrof naznačuje glas $j$ između samoglasnika: i'ûdei $\left(48 \mathrm{r}^{\mathrm{a}}\right)$ ili kod imenica na -je: pokaên'e $\left(48 \mathrm{v}^{\mathrm{a}}\right)$, vesel'e $\left(48 \mathrm{v}^{\mathrm{b}}\right)$. Nadalje, apostrof se bilježi na mjestu glasa $a$ u prijedlogu $n^{\prime}\left(48 \mathrm{r}^{\mathrm{a}}\right)$, kao i iza predmetka raz-: raz'mitati $\left(49 \mathrm{v}^{\mathrm{a}}\right)$. Česta je upotreba apostrofa uz slogotvorne $r$ i $l$ : $p r$ ' $v i\left(48 \mathrm{r}^{\mathrm{a}}\right)$, $d r^{\prime z ̌ e c i ~}\left(48 \mathrm{r}^{\mathrm{a}}\right), m r^{\prime} t v i h^{\prime}\left(48 \mathrm{v}^{\mathrm{a}}\right), d r^{\prime} v^{\prime}\left(49 \mathrm{r}^{\mathrm{a}}\right)$, sr'ce $\left(49 \mathrm{r}^{\mathrm{b}}\right)$, sl'n'ce $\left(48 \mathrm{v}^{\mathrm{b}}\right), n a p l$ 'ni se $\left(49 \mathrm{v}^{\mathrm{a}}\right)$ itd., premda ima slučajeva u kojima se oni pojavljuju i bez znaka za poluglas: $\operatorname{src}(e) m b\left(49 \mathrm{r}^{\mathrm{a}}\right), \operatorname{vrt}(a) p e\left(49 \mathrm{r}^{\mathrm{a}}\right), d r z ̌ e c \hat{i}\left(49 \mathrm{r}^{\mathrm{b}}\right)$. U FgTrans znak za poluglas uz slogotvorne $r$ i $l$ bilježi se svugdje, a osim apostrofa upotrebljava se i štapić: vl'nami (2c), ûtrbni (2a), prbvoe (2c) itd.

Apostrof se ponekad bilježi na različitim mjestima u riječima u odnosu na FgTrans: alek'sandrbscêem' (FgTrans 2c) / leksan'dr 'skom' (CVinod 48va) ili 
u riječima u kojima ga u FgTrans nema: markb (FgTrans 2b) / mar'ko (CVinod 48va ); bartolomêi (FgTrans 2c-d) / bar'tolomêi (CVinod 48va $)$.

Dok u FgTrans poluglas u jakome položaju najčešće nije vokaliziran: čbstnoe (1a), prišbdbše (1c), vbsb (3c) itd., poluglas je u CVinod uglavnom dosljedno vokaliziran samoglasnikom a: tada $\left(48 \mathrm{r}^{\mathrm{b}}\right)$, d'varem' $\left(49 \mathrm{r}^{\mathrm{a}}\right)$, sam' $\left(49 \mathrm{r}^{\mathrm{b}}\right)$, znutar' $\left(49 \mathrm{r}^{\mathrm{a}}\right)$, vani $\left(49 \mathrm{r}^{\mathrm{a}}\right)$, čast $^{\prime}\left(49 \mathrm{v}^{\mathrm{a}}\right)$ itd., a ima i primjera jake čakavske vokalizacije: va $\left(48 \mathrm{r}^{\mathrm{a}}\right)$, množastvo $\left(48 \mathrm{v}^{\mathrm{b}}\right), v a z$ 'mi $\left(48 \mathrm{r}^{\mathrm{b}}\right)$, važ' 'gati $\left(48 \mathrm{r}^{\mathrm{b}}\right), s a$ $\left(48 r^{b}\right)$ itd.

Kod nekih riječi susreće se neujednačeno pisanje, odnosno s vokaliziranim poluglasom, sa znakom za poluglas koji se bilježi apostrofom i bez znaka za poluglas: množastvo $\left(48 \mathrm{v}^{\mathrm{b}}\right)$ / množstvomb $\left(49 \mathrm{v}^{\mathrm{b}}\right)$ / množstvo $\left(48 \mathrm{v}^{\mathrm{b}}\right)$, odnosno sa znakom i bez znaka za poluglas: vit'lêomb $\left(48 \mathrm{v}^{\mathrm{a}}\right)$ / vitleomb $\left(48 \mathrm{r}^{\mathrm{a}}\right)$, vzd'viže $\left(48 \mathrm{v}^{\mathrm{b}}\right)$ / vzdviže $\left(49 \mathrm{r}^{\mathrm{b}}\right)$, te sa znakom za poluglas koji se bilježi štapićem i apostrofom : vitleomb $\left(48 \mathrm{r}^{\mathrm{a}}\right) /$ vitleom ' $\left(48 \mathrm{v}^{\mathrm{a}}\right)$ itd.

Za razliku od FgTrans, koji ili zadržava $B$ ili ga vrlo rijetko zamjenjuje samoglasnikom $e$, u CVinod je $\mathbb{B}$ mnogo slabije očuvan i ima ikavsko-ekavski odraz: s'mi $\left(48 \mathrm{r}^{\mathrm{a}}\right)$, divoike $\left(48 \mathrm{r}^{\mathrm{a}}\right)$, mis $(e) c b\left(48 \mathrm{v}^{\mathrm{b}}\right)$, nedil'ni $\left(49 \mathrm{r}^{\mathrm{a}}\right)$ i drugdje, svitla $\left(49 \mathrm{v}^{\mathrm{a}}\right)$, raz'mitati $\left(49 \mathrm{v}^{\mathrm{a}}\right)$, usiče $\left(49 \mathrm{v}^{\mathrm{a}}\right)$, vsed'se $\left(48 \mathrm{r}^{\mathrm{b}}, 48 \mathrm{v}^{\mathrm{a}}\right)$, sveca $\left(48 \mathrm{v}^{\mathrm{b}}\right)$, sredê $\left(48 \mathrm{v}^{\mathrm{a}}\right)$, veĉe $\left(48 \mathrm{v}^{\mathrm{b}}\right)$, celova $\left(49 \mathrm{r}^{\mathrm{b}}\right)$, cel' $\left(49 \mathrm{v}^{\mathrm{a}}\right)$.

Osim što $\mathrm{B}$ u CVinod i dalje dolazi na mjestima gdje se nalazi i u staroslavenskome: kolênê pres(ve)tê $\left(48 \mathrm{r}^{\mathrm{a}}\right)$, i'ûdêi bêhu $\left(48 \mathrm{r}^{\mathrm{a}}\right)$, priletê $\left(48 \mathrm{r}^{\mathrm{a}}\right)$, rêči $\left(48 \mathrm{r}^{\mathrm{a}}\right), \operatorname{sv}(\hat{e})$ tê $\left(48 \mathrm{r}^{\mathrm{a}}\right)$, nadêu $\left(48 \mathrm{r}^{\mathrm{a}}\right)$, vêruûi $\left(48 \mathrm{r}^{\mathrm{b}}\right)$, têlo $\left(48 \mathrm{r}^{\mathrm{b}}\right), v(i)$ tlêomb $\left(48 \mathrm{r}^{\mathrm{b}}\right)$, oblacêh' $\left(48 \mathrm{r}^{\mathrm{b}}\right)$, povêite $\left(48 \mathrm{r}^{\mathrm{b}}\right)$, mêstu, gradê epesê $\left(48 \mathrm{v}^{\mathrm{a}}\right)$, rimê $\left(48 \mathrm{v}^{\mathrm{a}}\right)$, An'drêi $\left(48 \mathrm{v}^{\mathrm{a}}\right)$, kananêi $\left(48 \mathrm{v}^{\mathrm{a}}\right)$, sredê $\left(48 \mathrm{v}^{\mathrm{a}}\right)$, bar'tolomêi $\left(48 \mathrm{v}^{\mathrm{a}}\right)$, propovêdae $\left(48 \mathrm{v}^{\mathrm{a}}\right)$, rucê $\left(48 \mathrm{v}^{\mathrm{b}}\right)$, grêšniki $\left(48 \mathrm{v}^{\mathrm{b}}\right)$, slêpi $\left(48 \mathrm{v}^{\mathrm{b}}\right)$, pêsni $\left(48 \mathrm{v}^{\mathrm{b}}\right)$, vidêv'še $\left(48 \mathrm{v}^{\mathrm{b}}\right)$, êmu $\left(49 \mathrm{r}^{\mathrm{a}}\right)$, vsêm' $\left(49 \mathrm{r}^{\mathrm{a}}\right)$, bl (a)g(o)dêt' $\left(49 \mathrm{r}^{\mathrm{a}}\right)$, prêdragi $\left(49 \mathrm{r}^{\mathrm{b}}\right)$, pês $(n b)$ pêti $\left(49 \mathrm{r}^{\mathrm{b}}\right)$, prosvêti $\left(49 \mathrm{r}^{\mathrm{b}}\right)$, rucê $\left(49 \mathrm{r}^{\mathrm{b}}\right)$, prês $(v e)$ ta $\left(49 \mathrm{v}^{\mathrm{a}}\right)$, vspêse pês $(n \mathrm{~b})\left(49 \mathrm{v}^{\mathrm{a}}\right)$, cêlb $\left(49 \mathrm{v}^{\mathrm{a}}\right)$, vidêse $\left(49 \mathrm{v}^{\mathrm{a}}\right)$, prêstola $\left(49 \mathrm{v}^{\mathrm{a}}\right)$ itd., njime se također označava glasovna skupina ja na početku, u sredini ili na kraju riječi: hoêše (48ra), $m(a)$ riê $\left(48 \mathrm{r}^{\mathrm{a}}\right)$, poêm 'ši $\left(48 \mathrm{r}^{\mathrm{a}}\right)$, br(a)tiê moê $\left(48 \mathrm{r}^{\mathrm{b}}\right)$, ê hoêhb $\left(48 \mathrm{r}^{\mathrm{b}}\right)$, pokaên'e $\left(48 \mathrm{v}^{\mathrm{a}}\right)$, êk $(o) v^{\prime}$ $\left(48 \mathrm{v}^{\mathrm{a}}\right)$, prestoêhu $\left(48 \mathrm{v}^{\mathrm{b}}\right)$, vapiêhu $\left(48 \mathrm{v}^{\mathrm{b}}\right)$, gospoê $\left(48 \mathrm{v}^{\mathrm{b}}\right)$, zn(a)m(e)niê $\left(48 \mathrm{v}^{\mathrm{b}}\right)$, b(o)žiê $\left(48 \mathrm{v}^{\mathrm{b}}\right)$, boêhu $\left(49 \mathrm{r}^{\mathrm{a}}\right)$, priêla $\left(49 \mathrm{r}^{\mathrm{a}}\right)$, s(vê)tlaê $\left(49 \mathrm{r}^{\mathrm{a}}\right)$, a (lelu) $\hat{e}\left(49 \mathrm{r}^{\mathrm{b}}\right)$, priê $\left(49 \mathrm{r}^{\mathrm{b}}\right)$, ofiniê $\left(49 \mathrm{v}^{\mathrm{a}}\right)$, priêti $\left(49 \mathrm{v}^{\mathrm{a}}\right)$.

U CVinod nema više staroslavenske glasovne skupine $\check{z} d$ kao u FgTrans: roždbi se (1d), vshoždahb (1d), koja prelazi u čakavsko $j$, koje je neoznačeno

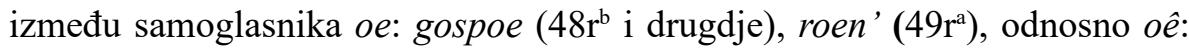
hoêse $\left(48 \mathrm{r}^{\mathrm{a}}\right)$, hoêhb $\left(48 \mathrm{r}^{\mathrm{b}}\right)$, gospoê $\left(48 \mathrm{v}^{\mathrm{b}}\right.$ i drugdje). Staroslavenski glas ę u CVinod prelazi u ja u oblicima glagola poêti i priêti: poêm 'ši $\left(48 \mathrm{r}^{\mathrm{a}}\right)$, priêla 
(49r $\left.\mathrm{r}^{\mathrm{a}}\right)$, priê $\left(49 \mathrm{r}^{\mathrm{b}}\right)$, priêti $\left(49 \mathrm{v}^{\mathrm{a}}\right)$, a ne u e kao u FgTrans: priemle (3c), priet' (3d).

Za razliku od FgTrans, u kojem je svugdje provedena druga palatalizacija, u CVinod to nije uvijek slučaj: ruci $\left(49 \mathrm{r}^{\mathrm{b}}\right)$, rucê $\left(49 \mathrm{r}^{\mathrm{b}}\right)$, oblacêh' $\left(48 \mathrm{r}^{\mathrm{b}}\right)$, druzi $\left(48 \mathrm{v}^{\mathrm{b}}\right)$, ali grêšniki $\left(48 \mathrm{v}^{\mathrm{b}}\right)$, tisuć 'niki $\left(48 \mathrm{v}^{\mathrm{b}}\right)$. U CVinod jednačenje po zvučnosti nije provedeno samo u riječi množstvo $\left(48 \mathrm{v}^{\mathrm{b}}\right)$, no ona na drugim mjestima dolazi sa znakom za poluglas ili samoglasnikom $a$, kojim se vokalizira poluglas.

U riječi pr'nesête (CVinod 48ra $\mathrm{r}^{\mathrm{a}}$ ) došlo je do ispadanja samoglasnika iza sekundarnog slogotvornog $r$, a nasuprot prinesi u FgTrans 1a. Zabilježen je i čakavski prijelaz samoglasnika $e$ u $a$ iza palatala: počaše (49ra) i drugdje, poča $\left(49 \mathrm{r}^{\mathrm{b}}\right)$, pored starijega poče $\left(48 \mathrm{r}^{\mathrm{a}}\right)$. U tekstu CVinod proveden je rotacizam, tj. intervokalno $\check{z}$ zamijenjeno je mlađim $r$ : nigdore $\left(48 \mathrm{r}^{\mathrm{a}}\right)$, nig'dore ne more $\left(49 \mathrm{r}^{\mathrm{a}}\right)$, ne more $\left(49 \mathrm{r}^{\mathrm{b}}\right)$, tere $\left(48 \mathrm{r}^{\mathrm{b}}\right)$ i drugdje. Na jednome mjestu u CVinod otpada početno $h$ ispred samoglasnika: oce $\left(48 \mathrm{r}^{\mathrm{b}}\right)$.

U fonološkoj prilagodbi grecizama, pseudogrecizama i grčkih vlastitih imena i od njih stvorenih pridjeva FgTrans i CVinod u mnogome se podudara-

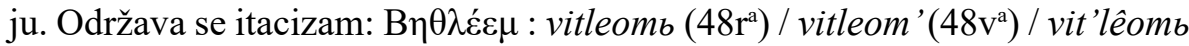

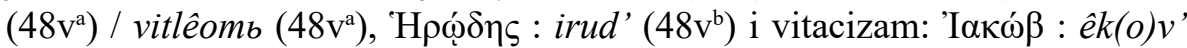

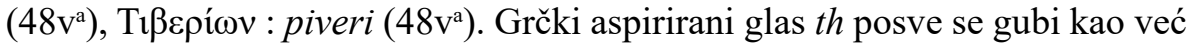
i u FgTrans: toma $\left(48 v^{a}\right)$, vitlêomb $\left(48 v^{a}\right)$ itd. Grčki glas $k h$, koji se označava

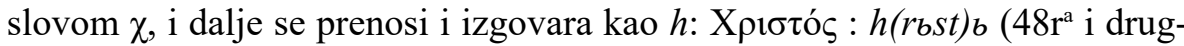

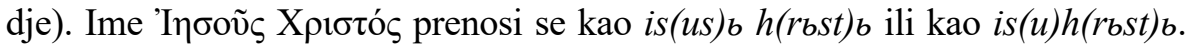
Kao već i u FgTrans grčko dugo o prelazi u $u$ : ¿́́ $\mu \omega v$ : simunb (1b) : simun $\left(48 \mathrm{v}^{\mathrm{a}}\right),{ }^{\prime} \mathrm{H} \rho \omega \dot{\delta} \eta \mathrm{\varphi}$ : irud' $\left(48 \mathrm{v}^{\mathrm{b}}\right), \dot{\eta} \gamma \varepsilon \mu \omega ́ v$ : emunь $\left(48 \mathrm{v}^{\mathrm{b}}\right)$, a ponekad i kratko $o$ :

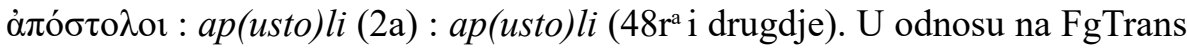
u CVinod primjetne su sljedeće promjene. U pridjevu leksan'dr'skom' CVinod $\left(48 v^{a}\right)$ došlo je do afereze, tj. ispadanja početnoga samoglasnika, koji je očuvan u FgTrans: alek'sandrbscêem' (2c). Dok se glas $p h$, koji se označava slovom

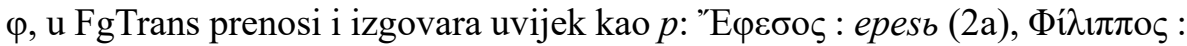

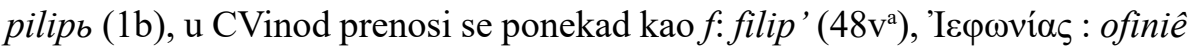

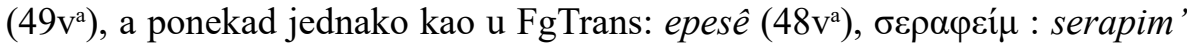
$\left(49 \mathrm{v}^{\mathrm{a}}\right)$. Grčki glas $t h$, koji se označava slovom $\theta$, kao i u FgTrans prelazi u $t$ : vit'lêomb $\left(48 \mathrm{v}^{\mathrm{a}}\right)$, toma $\left(48 \mathrm{v}^{\mathrm{a}}\right)$, bar'tolomêi $\left(48 \mathrm{v}^{\mathrm{a}}\right)$. Grčki glas $g$ u suglasničkoj

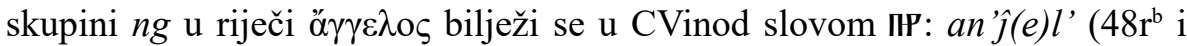
drugdje). To je ujedno jedina riječ u kojoj se u tekstu iz CVinod pojavljuje slovo IIP. 


\subsubsection{Morfologija}

Pomlađivanje jezika najmanje je izraženo u morfologiji. Većina oblika iz staroslavenskih deklinacija koji su zabilježeni u FgTrans čuvaju se također i u CVinod, ali najčešće pored mlađih oblika. Stariji oblik vokativa jednine muškoga roda na $-u$ čuva se u CVinod čak i bolje nego u FgTrans: sine (FgTrans $3 \mathrm{c})$ : sinu (CVinod 48ra $\mathrm{r}^{\mathrm{a}}$ i drugdje. Jednako se tako dosljedno čuva i vokativ jednine ženskoga roda na $-e$ : marie $\left(\mathrm{CVinod} 48 \mathrm{r}^{\mathrm{a}}\right) .{ }^{19}$

U morfološkoj prilagodbi grecizama, pseudogrecizama i grčkih vlastitih

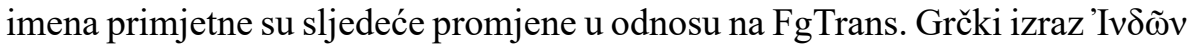
$\chi \omega ́ \rho \alpha$ 'zemlja Indijaca' ne prenosi se pridjevom in'diiskû̂ stranu (FgTrans 2b), nego imenom zemlje: in'dii (CVinod 48v'). Ime mar'ko (CVinod 48va) s nastavkom -o iznimka je od pravila da slavenska imena kojima se prevode

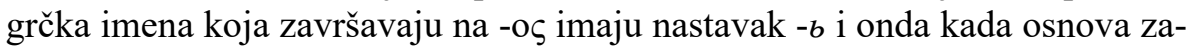
vršava suglasničkom skupinom: Mápко : markb (FgTrans 2b).

U CVinod daleko su rjeđi dulji padežni nastavci pridjeva. Pridjevi u nominativu i akuzativu jednine srednjega roda samo na jednom mjestu imaju nasta-

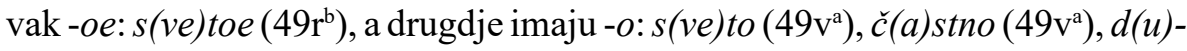
h(o)vno $\left(48 \mathrm{v}^{\mathrm{b}}\right)$, straš 'no $\left(48 \mathrm{v}^{\mathrm{b}}\right)$, čisto $\left(49 \mathrm{r}^{\mathrm{b}}\right)$, dočim su u FgTrans isključivo na -oe: prêpodobnoe (1a), mutnoe (2c), mnogohval'noe (2d, 3a), čbstnoe (3a), smêrenoe (3b), blagoe (3c), $s(v e)$ toe (3c). Također u genitivu jednine muškoga i srednjega roda nemaju nastavak -ago: živago (FgTrans 3c), č(lovế) [s] $]$ kago (FgTrans 3b), nego -oga: patomos'koga (CVinod 48r ${ }^{b}$ ), n(e)b(e)skoga $\left(C V i n o d 49 \mathrm{v}^{\mathrm{a}}\right)$, dok u lokativu muškoga roda nemaju nastavak -êemb, nego -om: alek'sandrbscêem' (FgTrans 2c) : leksan'dr 'skom '(CVinod 48va ). Pridjevi u nominativu jednine ženskoga roda u CVinod imaju pretežno kraći nastavak -a: s(ve)ta (CVinod 48v i drugdje), a ne više -aê: s(ve)taê (FgTrans 1a i drugdje), a u akuzativu ženskoga roda nemaju nastavak -uû, nego -u: nepo[ročnu] $\hat{u}$

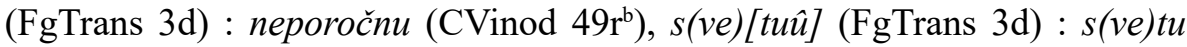
$($ CVinod 49ra).

U osobnim zamjenicama češće se javlja oblik s početnim $n-:$ nei $\left(48 \mathrm{r}^{\mathrm{a}}\right)$, nega (48r ${ }^{\mathrm{a}}$ i drugdje), nego u FgTrans. Prvo lice jednine osobne zamjenice u lokativu glasi $m n i\left(49 \mathrm{r}^{\mathrm{a}}\right)$. Rjeđi je nastavak =ego za genitiv jednine osobnih zamjenica muškoga i srednjega roda. Zamjenica $s b$, si, se nije više tako česta kao u FgTrans, nego se pojavljuje uglavnom u izrazima sega $s v(\hat{e}) t a\left(48 \mathrm{r}^{\mathrm{b}} \mathrm{i}\right.$ drugdje), semb sv(ê)tê (48ra $)$. Zamjenica $a z b$, koja je u FgTrans vrlo česta, u

${ }^{19}$ Podrobnija morfološka analiza teksta iz CVinod nalazi se u sljedećem poglavlju ovoga rada, u kojem se taj tekst uspoređuje s tekstom iz CGrš. 
CVinod još je u tom obliku očuvana samo na jednome mjestu, a umjesto nje nastupa oblik $\hat{e}$. U CVinod više nema zamjenice $k b \check{z} d o$ (FgTrans 1d), nego samo vs $(a) k a\left(49 \mathrm{r}^{\mathrm{b}}\right)$. Gube se i zamjenice s česticom že: eeže (FgTrans 3a), nemuže (FgTrans 1d), nim'že (FgTrans 1b), osim zamjenice nigdore (CVinod $48 \mathrm{r}^{\mathrm{a}}$ i 49r $\left.\mathrm{r}^{\mathrm{a}}\right), \mathrm{u}$ kojoj inervokalno $\check{z}$ rotacizmom prelazi $\mathrm{u} r$.

Stari glagolski nastavci zamjenjuju se mlađima u prezentu trećega lica jednine: prizivaetb (FgTrans 3c) : priziva (CVinod 49r $\mathrm{r}^{\mathrm{b}}$ ) i trećega lica množine: mogut' (FgTrans 3a) : more (CVinod 49ra i drugdje). Stariji je nastavak očuvan samo u riječi raduet'se (CVinod 49r ${ }^{\mathrm{b}}$ ) i u trećem licu jednine prezenta glagola biti: $e$ (stb) (CVinod 48ra i drugdje). Kod glagola $e$-konjugacije imperativ drugoga lica množine na -ête: idête (FgTrans 2a) dobiva nastavak -ite: poidite $\left(\mathrm{CVinod} 48 \mathrm{r}^{\mathrm{b}}\right)$. Umjesto izraza g(lago)la k'mnê (FgTrans 1d-2d) sve češći je izraz reče $m i\left(48 \mathrm{v}^{\mathrm{a}}\right)$.

Nastavci za participe pojednostavljeni su i ujednačeni u odnosu na oblike iz FgTrans. Preostali su samo participi s nastavkom za nominativ jednine i množine, koji se pretvaraju u glagolske priloge. U CVinod rijetko su očuvani participi u istom obliku u kojem su i u FgTrans: propovêdae (FgTrans 2d) : propovêdae (CVinod 48v $)$; [drbž]eĉi $($ FgTrans 3a) : dr'žeĉi $($ CVinod 48ra); pr[oslavle]na bud[et'] (FgTrans 3c) : budu pros 'lavlena (CVinod 49rb). Samo su mjestimično zabilježeni prvi aktivni participi preterita na -b/-bši: poêm'ši $\left(48 \mathrm{r}^{\mathrm{a}}\right)$, vsed 'še $\left(48 \mathrm{r}^{\mathrm{b}}, 49 \mathrm{v}^{\mathrm{a}}\right)$ i na -vb/-vbši: slišav'ši $\left(48 \mathrm{r}^{\mathrm{a}}\right)$, vidêv'še $\left(48 \mathrm{v}^{\mathrm{b}}\right)$, obrativ'se (49rb), dočim su u FgTrans vrlo česti: prêšsbdb (2b), osênb (2c), obraĉ ... se (3d), poklon'še se (1c), približ'šu se (1c), v'zmuĉšš se (2c), stvor'šei (3a), pomol'ši se (3b), tek'še (3d), vzved [ši] se (3d), načenšu (3d), otveĉav'ši (1a), vzradovav'š $[i]$ (1c), izvoliv se (3a) itd. U aktivnom participu prezenta u nominativu jednine muškoga roda očuvao se stari oblik na -e: poslušae $\left(48 \mathrm{v}^{\mathrm{a}}\right)$, nose $\left(49 \mathrm{v}^{\mathrm{b}}\right)$, hode $\left(48 \mathrm{r}^{\mathrm{a}}\right)$, a u nominativu jednine ženskoga roda -ĉi: poklanaûci $i$ $\left(48 \mathrm{r}^{\mathrm{a}}\right)$, poziraûci $\left(48 \mathrm{r}^{\mathrm{a}}\right), d r^{\prime}{ }^{\prime} e \hat{e} i\left(48 \mathrm{r}^{\mathrm{a}}\right)$ itd. Pasivni particip prezenta potpuno se izgubio u CVinod.

Za razliku od FgTrans, koji futur tvori uz pomoć glagola imêti, CVinod tvori futur uz pomoć glagola hotêti, npr. prêstavlena imat' biti (FgTrans 2a) : hoĉe se prestaviti $\left(\mathrm{CVinod} 48 \mathrm{v}^{\mathrm{a}}\right)$.

Nema više nastavka za prvo lice množine asigmatskoga aorista -omb, kao ni za treće lice množine - $u$, koji se još čuvaju u FgTrans: pridom' (1c), vzdahom' (3d), ohopihom' (3d), pridu (2d). Nema ni staroga oblika za prvo lice jednine prvoga sigmatskoga aorista rêhb (FgTrans 1a, 1d) i prvo lice množine rêhomb (FgTrans 1c). 
Dok se u FgTrans glagol biti pojavljuje isključivo u proširenim oblicima: estb (3a), esi (2d, 3b), u CVinod pojavljuje se i u skraćenim oblicima: e (49ra $\mathrm{i}$ drugdje) pored $e(s t b)\left(48 \mathrm{r}^{\mathrm{a}}\right.$ i drugdje), si $\left(49 \mathrm{r}^{\mathrm{a}}\right)$ pored esi $\left(49 \mathrm{v}^{\mathrm{a}}\right)$ te $s a m^{\prime}\left(49 \mathrm{r}^{\mathrm{b}}\right)$ i su $\left(48 \mathrm{r}^{\mathrm{a}} \mathrm{i}\right.$ drugdje).

\subsubsection{Sintaksa}

Utjecaj grčkoga jezika, koji je na oblikovanje hrvatskostaroslavenskoga jezika u FgTrans najviše do izražaja došao u sintaksi, u CVinod je znatno manji.

Pomlađivanje jezika u usporednim dijelovima tekstova očituje se ponajprije u upotrebi participa. Naime, u CVinod više se ne slijedi grčka sintaksa participa, odnosno gotovo je potpuno izgubljena upotreba participa kojima se doslovno prenose grčki participi u odgovarajućem rodu, broju i padežu, bez razrješavanja participskih konstrukcija u zavisne rečenice. Hrvatskostaroslavenski participi, kojima su u FgTrans doslovno prevedeni grčki participi, u hrvatsko-staroslavenskom jeziku u CVinod pretvaraju se u indikative i zavisne rečenice.

U predikatnoj upotrebi u grčkoj konstrukciji akuzativa s participom i genitiva s participom particip se razrješava odnosnom rečenicom s odnosnom za-

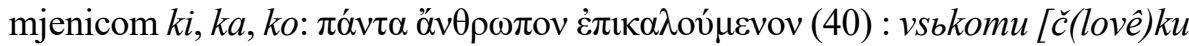
pr]iziva[ûcu (FgTrans 3b) : vs(a)k(o)mu č(lovê)ku ki priziva (CVinod 49rb);

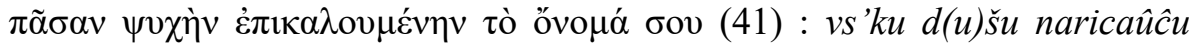
ime tvoe (FgTrans 3b) : vs(a)ka d(u)ša ka priziva ime čisto (CVinod 49r $\left.{ }^{\mathrm{b}}\right)$;

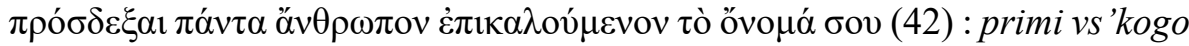
$\check{c}($ lovê)ka prizivâ̂cago ime tvoe s(ve)[toe] (FgTrans 3c) : budi mil(o)st(i)v' vs(a)k(o)mu č(lovê) ku ki priziva ime s(ve)toe moe (CVinod 49r $\mathrm{r}^{\mathrm{b}}$ ) ili se razrješava nezavisnom rečenicom povezanom veznikom $i$ :

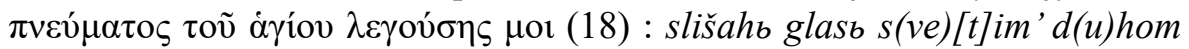
g(lago)luĉb k' mnê (FgTrans 2a) : id(u)h's(ve)ti r(e)č(e) mi (CVinod 48va).

Participi u adverbnoj upotrebi razrješavaju se $\mathrm{u} C$ Vinod također nezavisnom rečenicom: $\dot{\varepsilon} \xi \varepsilon \gamma \varepsilon \rho \theta \dot{v} v \tau \varepsilon \varsigma \dot{\varepsilon} \kappa \tau \tilde{\omega} v \mu \nu \eta \mu \varepsilon i ́ \omega v(13)$ : vstavbše iz' grobb (FgTrans

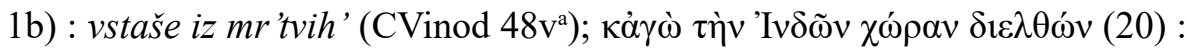
$i$ azb in'diiskuû stranu prêšbdb (FgTrans $2 \mathrm{~b})$ : bih'v in'dii (CVinod $\left.48 \mathrm{v}^{\mathrm{a}}\right)$; $\kappa \alpha \grave{~}$

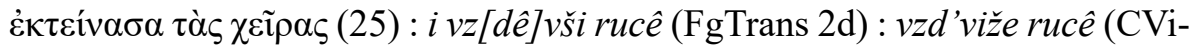

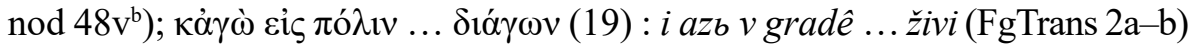
: bih'v gradi piveri (CVinod 48v'). Participi otvecavb (FgTrans 1a, 1d, 2a, 2b, 2c) i otveĉav'ši (FgTrans 1a, 2c, 3a), kojima se na početku rečenica doslovno prevode

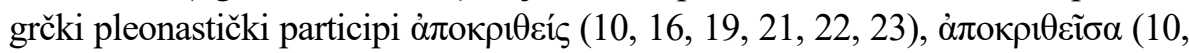




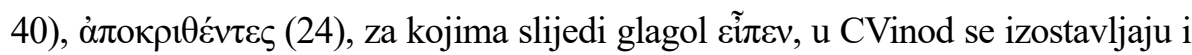
zadržava se samo indikativ aorista $r(e) \check{c} e$ ( $48 \mathrm{r}^{\mathrm{a}} \mathrm{i}$ drugdje).

Većina participa više ne slijedi starije slavenske participe u broju, rodu i padežu, još manje u vremenu i načinu, nego su najčešće u nominativu jednine ženskoga roda, te su postali glagolski prilozi: poklanaûci $\left(48 \mathrm{r}^{\mathrm{a}}\right)$, poziraûci $\left(48 \mathrm{r}^{\mathrm{a}}\right)$, dr 'žeĉi $\left(48 \mathrm{r}^{\mathrm{a}}\right)$, videcii $\left(48 \mathrm{r}^{\mathrm{a}}\right)$, govoreĉi $\left(48 \mathrm{r}^{\mathrm{b}}\right)$, gredoĉi $\left(48 \mathrm{v}^{\mathrm{b}}\right)$, držeĉi $\left(49 \mathrm{r}^{\mathrm{b}}\right)$, i u nominativu množine muškoga roda hoteĉi $\left(49 \mathrm{r}^{\mathrm{a}}\right)$, ili služe kao sastavnica za tvorbu futura, perfekta, pluskvamperfekta i kondicionala.

U FgTrans na dvama se mjestima pojavljuje apsolutni dativ približ'šu se

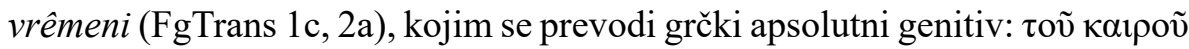

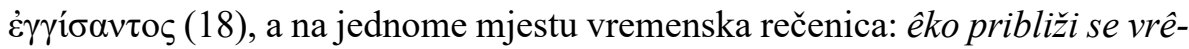
me (2a), dočim se u CVinod susreće samo još jednostavna rečenica: približi se vr(ê)me (49r $\left.\mathrm{r}^{\mathrm{b}}\right)$, u kojoj se imenica u dativu, koja prenosi grčku imenicu u genitivu, zamjenjuje imenicom u nominativu, a prvi aktivni particip preterita približ'šu se u dativu, koji prenosi grčki particip aorista u genitivu, zamjenjuje se indikativom aorista približi se. Isti postupak primijenjen je i u sljedećim

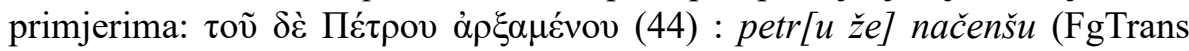

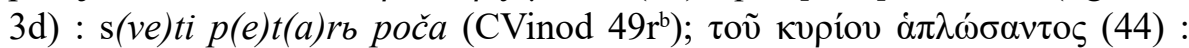
g(ospod)u prostrbvšu (FgTrans 3d) : a b(o)gb prostri (CVinod 49rb); $\dot{\varepsilon} \mu \mathrm{ov}$ ह่v

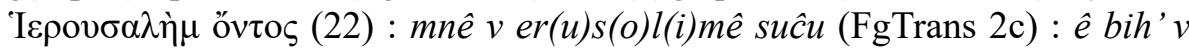

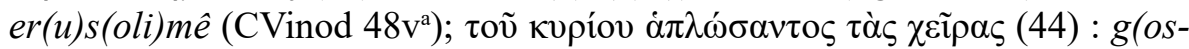
pod) u prostrbvšu rucê (FgTrans 3d) : b(o)gb prostri ruci svoi (CVinod 49r $\mathrm{r}^{\mathrm{b}}$ ). Nijedan apsolutni dativ iz FgTrans kojim se prenosi grčki apsolutni genitiv nije očuvan u CVinod. Apsolutni dativ suĉu mi v mori (FgTrans 2c), kojim

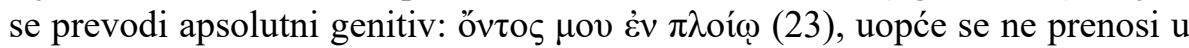
CVinod, a u CGrš razrješava se opet jednostavnom rečenicom: $\hat{e}$ bihi na mori (CGrš 169r).

I sve druge participske konstrukcije koje se nalaze u FgTrans uglavnom se u CVinod razrješavaju zavisnim rečenicama. Glagol ع̌ $\chi \omega \mathrm{s}$ infinitivom aori-

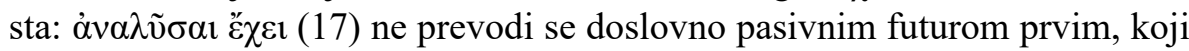
se tvori od pasivnoga participa prezenta: prêstavlena imat' biti (FgTrans 2a), nego futurom prvim s pomoćnim glagolom hotêti: hoĉe se prestaviti (CVinod $\left.48 v^{a}\right)$. U CVinod nalazi se rijetko koji poimeničeni pridjev, kojim se prenosi grčki poimeničeni pridjev: $s$ (ve)taê (FgTrans 3c) : s(ve)tih' (CVinod 48v'),

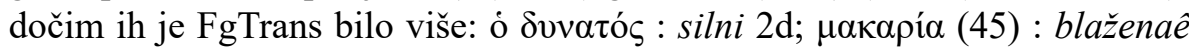

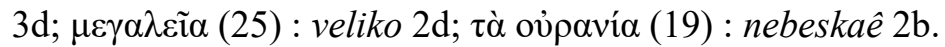

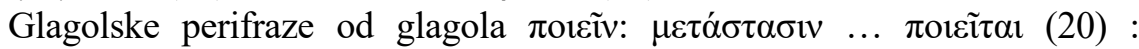

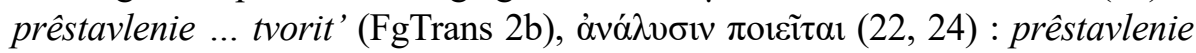


tvorit' (FgTrans 2c, 2d) više se ne prevode doslovno: bi prestavilb (CVinod 48ra); su se prestavili $\left(\mathrm{CVinod} 48 \mathrm{r}^{\mathrm{a}}\right)$; hoce se prestaviti $\left(\mathrm{CVinod} 48 \mathrm{v}^{\mathrm{a}}\right)$. Izraz stvoriti

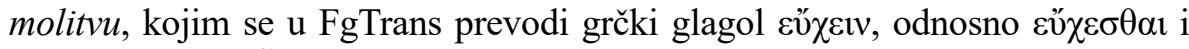

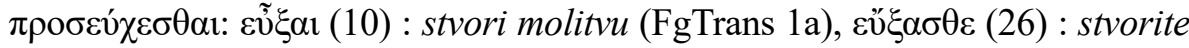

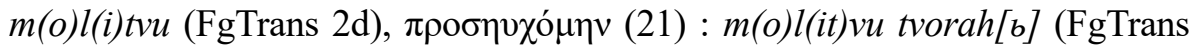
2c), na jednome se mjestu u CVinod preuzima: tvoriti $m(o) l(i) t v u\left(48 \mathrm{r}^{\mathrm{a}}\right)$, na drugome mjestu nalazi se: $m(o) l(i) t i$ se $\left(49 \mathrm{v}^{\mathrm{a}}\right)$, a na trećem se $m(o) l($ it) $)$ u tvorahb (FgTrans 2c) preinačuje u pokaên'e činah' (CVinod 48va).

Prijedlog $k / k$ ', kojim se u FgTrans prevodi grčki prijedlog $\pi \rho o ́ \varsigma$, dobro je očuvan u prijedložnim izrazima: $r(e) \check{c} e ~ g(o s p o d)_{b} k$ materi svoei (CVinod 49ra $)$, obrativ'se b(og)b ks(ve)t(o)mu [petru] (CVinod 49r $\left.{ }^{\mathrm{b}}\right)$, poča m(o)l(i)ti se $k r(u)$ ci $\left(\right.$ CVinod $\left.49 \mathrm{v}^{\mathrm{a}}\right)$.

Jedan je od rijetkih preostalih sintaktičkih grecizama doslovan prijenos

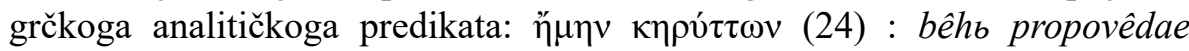
(FgTrans $2 \mathrm{~d})$ : bih' propovêdae (CVinod $\left.48 \mathrm{v}^{\mathrm{a}}\right)$. U CVinod $48 \mathrm{v}^{\mathrm{a}}$ nalazi se još jedan takav predikat: bihi poslušae, koji se ne nalazi u FgTrans.

Osobna zamjenica u posvojnom genitivu još uvijek se mjestimice prenosi

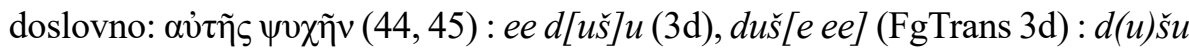
ee $\left(\mathrm{CVinod} 49 \mathrm{v}^{\mathrm{b}}\right)$, ali pretežno se razrješava posvojnom zamjenicom: tò ỏvouó

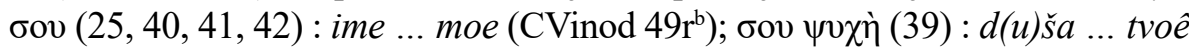
(CVinod 49ra ), što je primjetno već u FgTrans: ime tvoe (FgTrans 2d, 3a, 3b, $3 \mathrm{c})$, tvoê $d(u) \check{s} a$ (FgTrans 3a).

Imenica u posvojnom genitivu više se ne prenosi imenicom, kao što je to još često slučaj u FgTrans, nego pridjevom u istom padežu u kojem je i imeni-

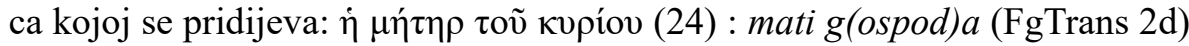

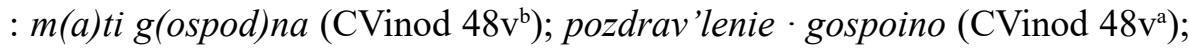
$d(u) \check{s}$ a gospoina $\left(49 \mathrm{v}^{\mathrm{a}}\right) ;$ sl $(a)$ va $b(o) z ̌ i e ̂\left(48 \mathrm{v}^{\mathrm{b}}\right)$ itd.

U CVinod nema više česte upotrebe instrumentala kojim se u FgTrans dosljedno prenose grčki prijedložni izrazi s genitivom, dativom i akuzativom, a jedino je preostao izraz $d(u) h(o) m b$ s[(ve)timb] (CVinod 48r ${ }^{\text {b }}$ ) : s(ve)timb d(u)hom' (FgTrans 1c), koji se na jednom mjestu pretvara u nominativ: $d(u) h$ 's(ve)ti $\left(\mathrm{CVinod} 48 \mathrm{v}^{\mathrm{a}}\right)$, a instrumental ish[ožden]iem' (FgTrans 3d) razrješava se u zavisnu vremensku rečenicu: kada izide (CVinod $\left.49 \mathrm{v}^{\mathrm{a}}\right)$.

$\mathrm{Na}$ jednom se mjestu glagolska imenica iz FgTrans pretvara u CVinod u infinitiv: načni pênie FgTrans 3d : počni pês(nb) pêti CVinod 49r ${ }^{\mathrm{b}}$, čime se tekst iz CVinod udaljava od grčkoga izvornika ő $\rho \xi \alpha \iota \tau \tilde{~} \tau \dot{v} \mu \nu \omega \delta i ́ \alpha \varsigma^{20}$

${ }^{20}$ Usporedbu teksta iz FgTrans s grčkim izvornikom vidi u MIKECIN 2018: 240-255. 


\subsubsection{Leksik}

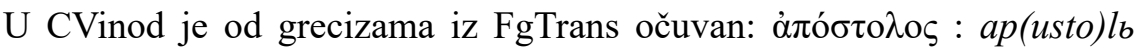

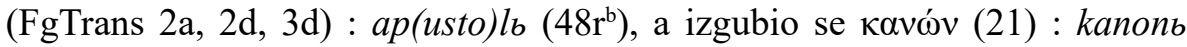
(FgTrans 2c). Grčki latinizam $\pi \alpha \lambda \alpha ́$ ćov (20) : polača (FgTrans 2b) : polača $\left(48 v^{a}\right)$ također je očuvan, jednako kao i grčki semitizam $\alpha \lambda \lambda \eta \lambda$ ov́ï $\alpha$ (44) : ale-

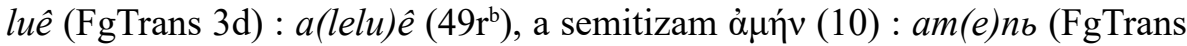
1a) u CVinod nije zabilježen.

U CVinod nema spomena grada Tebe, koji se spominje u grčkom izvorniku i u FgTrans, jednako kao ni apostola Matije. U prijenosu imena $\Lambda \alpha \beta \delta \alpha v o v \varsigma s$ (20) : lav'danusb (FgTrans 2b) došlo je do znatnog iskrivljavanja: al'vana $\left(C V i n o d 48 v^{a}\right)$. Ime grada Tıßepí $\omega v(12,19)$ : tiverionb (FgTrans 1b, 2b) iskrivljeno je u piveri $\left(\mathrm{CVinod} 48 \mathrm{v}^{\mathrm{a}}\right)$.

U CVinod nema nekih teoloških naziva koji se nalaze u FgTrans: $\alpha$ ód $\lambda v \sigma 1 \varsigma$

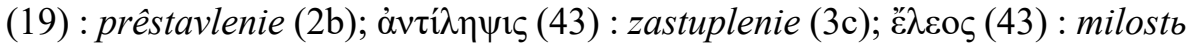

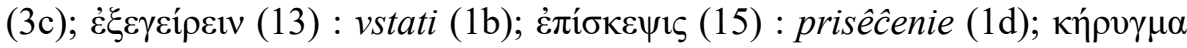

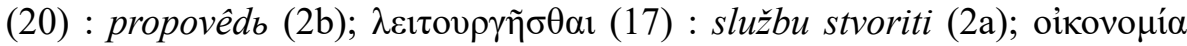

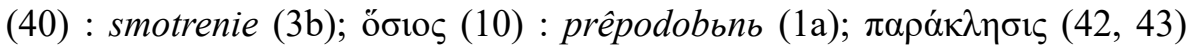

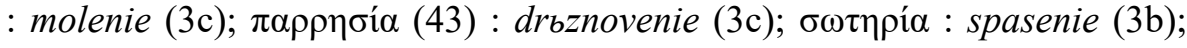

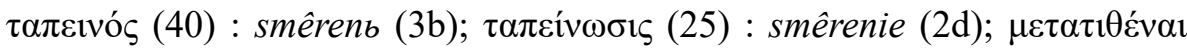
(39) : prêložiti (3a).

Općenito se gube imenice s dometkom -ie, koje su česte u FgTrans: istlênie (1a), tečenie (2b), vl'nenie (2c), pr[inoše]nie (3c), ili im se zamjenjuje dometak, kao što se primjerice pênie iz FgTrans 3d pretvara u pês(nb) (CVinod $49 \mathrm{r}^{\mathrm{b}}$ ), a zabilježene su riječi pozdrav'lenie ( $48 \mathrm{v}^{\mathrm{a}} \mathrm{i}$ drugdje) umjesto cêlovanie iz FgTrans, zatim $z n(a) m(e) n i e \hat{~}\left(48 \mathrm{v}^{\mathrm{b}}\right)$ i veselie $\left(49 \mathrm{r}^{\mathrm{a}}\right)$, te riječi pisane s apostrofom: pokaên'e $\left(48 \mathrm{v}^{\mathrm{a}}\right)$, vesel'e $\left(48 \mathrm{v}^{\mathrm{b}}\right)$.

Pomlađivanje leksika vidljivo je u sljedećim primjerima: Riječ mirb (FgTrans

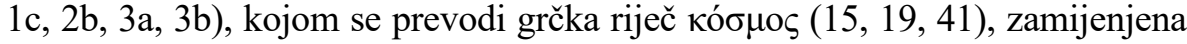
je riječju $s\left(v e \hat{)} t_{b}\left(C V i n o d 48 r^{a}\right)\right.$. Tamo gdje FgTrans ima na cêlovanie ee (2a) CVinod ima na pozdrav'lenie $\left(48 v^{a}\right)$. I neke druge riječi iz FgTrans zamijenjene su u CVinod: [lo]bizaše (FgTrans 3a) : celova (CVinod 49rb); prispê (FgTrans 3d) : približi se (CVinod 49r $\left.{ }^{\mathrm{b}}\right)$. Umjesto zamjenice êže (FgTrans 3c) i zamjenice kotorôि (FgTrans 2d) upotrebljava se zamjenica $k a\left(C V i n o d ~ 49 r^{b}\right)$.

U tvorbi riječi stariji se predmetci zamjenjuju mlađima ili samo uobičaje-

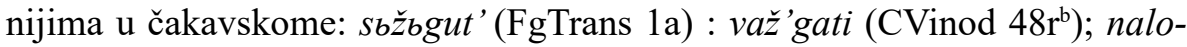
$\check{z} i$ (FgTrans 3a) : položi (CVinod 49ra); načni (FgTrans 3d) : počni (CVinod 49r'); ispl'ni se (FgTrans 3d) : napl'ni se (CVinod 49v'). 
U CVinod izgubili su se prilozi pače (FgTrans 3d), sice (FgTrans 3b), vku$p b$ (FgTrans 1c), a vrlo je čest prilog simo (48 $\mathrm{r}^{\mathrm{b}}$ i drugdje), kojega nema $\mathrm{u}$ FgTrans. Veznik že, kojim se redovito prevodi grčki veznik $\delta \varepsilon ́$, gubi se ili zamjenjuje veznikom $a$, a veznik i prilog êko (FgTrans $1 \mathrm{~b}$ i drugdje) povlači se pred veznikom $d a\left(C \operatorname{Cinod} 48 \mathrm{r}^{\mathrm{a}}\right)$ i veznikom i prilogom kada (CVinod $48 \mathrm{v}^{\mathrm{b}}$ i drugdje). Iščezao je veznik bo (FgTrans 1d, 3c), kojim se u FgTrans prevodi grčki veznik $\gamma \alpha$ ó $\rho$, kao i veznik $n a$ (FgTrans $2 b)$, kojim se prevodi grčki veznik $\dot{\alpha} \lambda \lambda \alpha \dot{\alpha}$. Veznik i prilog egda (FgTrans 1d) zamjenjuje se veznikom i prilogom kada (CVinod 48r ${ }^{\mathrm{b}}$ i drugdje), a veznik idêže (FgTrans 2a, 2b, 3a, 3c) veznikom $k^{\prime} d i\left(\mathrm{CVinod} 49 \mathrm{r}^{\mathrm{a}}\right)$.

\subsection{Tekstološka analiza}

S obzirom na to da je apokrif u FgTrans sačuvan fragmentarno, u njemu nedostaju dijelovi teksta od početka apokrifa, u kojem je riječ o tome da Marija dolazi na Isusov grob u Jeruzalemu i moli da ju sin uzme k sebi, navještenje arkanđela Gabrijela Mariji da su njezine molitve uslišane i da će uskoro umrijeti i da će ju Isus uznijeti na nebo u vječni život, Marijin odlazak u Betlehem, molba Isusu da joj pošalje apostola Ivana i sve druge apostole kako bi svjedočili njezinu uznesenju, dolazak apostola Ivana i njegov razgovor s Marijom i molitva Isusu za čudo Marijina uznesenja. FgTrans 1a sadrži Ivanovo obećanje Mariji da Židovi neće oskvrnuti njezino tijelo nakon smrti i Marijin nalog Ivanu da se ponovno pomoli Isusu za nju. Zatim u FgTrans nedostaje tekst u kojem Ivan najavljuje dolazak apostola Petra, Pavla, Tome, Jakova, Andreja, Filipa i Šimuna po Duhu Svetom sa svih krajeva svijeta u Betlehem. ${ }^{21} \mathrm{U}$ FgTrans $1 \mathrm{~b}$ nabrajaju se svi apostoli i mjesta odakle dolaze $\mathrm{k}$ Mariji, kako im je zapovjedio Duh Sveti. Potom nedostaje tekst u kojem Ivan objašnjava apostolima zašto su pozvani doći u Betlehem te spominje dolazak Markov i opisuje dolazak Petrov. U FgTrans 1c apostoli se klanjaju Mariji i obraćaju joj se kao majci Božjoj koja će uskoro biti uznesena. Nakon toga nedostaje tekst u kojem se kaže da je Marija vidjevši apostole povjerovala u uznesenje te zatražila da joj ispripovijedaju odakle i kako su došli k njoj. U FgTrans 1d-2d sačuvan je neprekinut tekst apokrifa u kojem apostoli opisuju

${ }^{21}$ Kako u FgTrans tako i u CVinod i CGrš apostoli koji dolaze Mariji nisu svi pravi apostoli, tj. Dvanaestorica. Uz Ivana, Petra, Andriju, Filipa, Šimuna Kananejca, Tomu, Jakova, Bartolomeja i Mateja u apostole su ubrojeni i novozavjetni pisci Marko, Luka i Pavao, a poimence se ne spominju Jakov Alfejev, Juda Tadej i Juda Iškariotski, ali se u CVinod napominje da su došli i svi drugi apostoli: pridoše vsi ap (usto)li $\left(48 \mathrm{v}^{\mathrm{a}}\right)$, čega nema u CGřs. 
svoj dolazak sve do završne molitve Isusu. Zatim nedostaje tekst koji govori o tome kako se Isus ukazao u Betlehemu u Marijinu domu te kako se tamo okupilo mnoštvo vjernika, kako su mnogi čudesno izliječeni, i kako su svi slavili Isusa i Mariju. Isto tako nedostaje tekst o tome kako su se židovski svećenici, ispunjeni zavišću zbog onoga što su vidjeli, obratili svojemu prvosvećeniku tražeći od njega da progna Mariju i apostole iz Betlehema, kako su oni pred židovskim vojnicima pobjegli u Jeruzalem uz pomoć Duha Svetoga, kako su u Jeruzalemu Židovi ustali protiv njih i pokušali zapaliti Marijin dom, što je čudom spriječeno, te kako su u Jeruzalemu mnogi ljudi povjerovali u Isusa $\mathrm{i}$ Mariju. U daljnjem nesačuvanom tekstu riječ je o nedjelji kao svetom danu, na koji su se dogodili svi za kršćanstvo važni događaji i na koji će i Marija biti uznesena. FgTrans 3a-d sadrži Isusovu najavu Marijina uznesenja, blagoslov Marije, njezinu molitvu Isusu za spas svakoga tko bude slavio nju kao majku Božju i Isusa kao njezina sina, Isusov odgovor na tu molitvu, Petrov hvalospjev pred Marijinu smrt, Marijin blagoslov apostola, preminuće Marijino i Isusovo primanje Marijine duše.

Tekst iz CVinod sadrži cijeli apokrif, ali u vrlo skraćenom i sažetom obliku. To skraćivanje najveće je u dijelu teksta koji govori o dolasku apostola Ivana k Mariji i razgovoru između njih dvoje, Ivanovoj molitvi Isusu za Mariju, Ivanovu obraćanju apostolima kada ih poziva da dođu k Mariji u Betlehem. Skraćen je i opis odakle i kako su apostoli pristigli te razgovor između Marije i apostola i molitva apostola za Mariju. Nakon opisa kako se okupljaju vjernici pred Marijinim domom skraćen je izvještaj o židovskim svećenicima koji su naumili prognati Mariju iz Betlehema. Najveća preinaka i sažimanje sastoji se u tome da se u CVinod preskače upad židovskih vojnika u Marijin dom u Betlehemu, a tekst koji se u slavenskome predlošku odnosi na njihov dolazak u dom u Jeruzalemu upotrebljava se za opis napada u Betlehemu, jer u CVinod nije izričito spomenut Marijin odlazak iz Betlehema u Jeruzalem, kao ni okupljanje ljudi pred Marijinim domom u Jeruzalemu, premda se kasnije kaže da je Marija izdahnula u Jeruzalemu. Također je znatno skraćena velika Marijina molitva Isusu u kojoj se moli zaštita za sve vjernike koji će nju slaviti kao njegovu majku.

Tekstovi FgTrans i CVinod tekstološki su usporedivi do mjesta CVinod $49 v^{\mathrm{a}} 4$, nakon kojega slijedi tekst koji u FgTrans nedostaje jer tu završava posljednji sačuvani fragment $3 \mathrm{~d}$. U odnosu na prvobitni slavenski prijevod u daljnjem tekstu iz CVinod Židov Jefonija nasrće na odar s Marijinim tijelom, koje apostoli prenose u raj, nakon čega slijedi čudo Jefonijina iscjeljenja, obraćenje prisutnih, slavlje vjernika i nebeskoga Jeruzalema u Marijinu 
čast te na samome kraju Isusov dolazak s anđelima i arkanđelima i drugim svetima, uzeće Marijine duše i sjedinjenje duše s tijelom na nebu. U starijim slavenskim tekstovima, jednako kao u i grčkom izvorniku, apostoli na dvanaest oblaka prenose Marijino tijelo u raj, gdje mu se klanjaju Ivanova majka Elizabeta, Marijina majka Ana, Abraham, Izak, Jakov i David, te na kraju proslavljaju Isusa Krista, koji je uzveličao svoju majku.

\section{USPOREDNA JEZIKOSLOVNA I TEKSTOLOŠKA ANALIZA APOKRIFA USNUĆE BOGORODICE IZ VINODOLSKOGA ZBORNIKA I GRŠKOVIĆEVA ZBORNIKA}

\subsection{Jezikoslovna analiza}

\subsubsection{Fonologija i grafija}

Dok je znak za poluglas u tekstu iz CVinod, kao što smo vidjeli, dobro očuvan i na mnogim se mjestima na kraju riječi bilježi štapićem, a još češće apostrofom, koji se upotrebljava također i u sredini riječi, u tekstu iz CGrš nema znaka za poluglas.

Vokalizacija poluglasa glasom $a$ zajednička je obama tekstovima, no u CGrš ona je još češća nego u CVinod: množastvo $(169 \mathrm{v})$, cesarastvo $(167 \mathrm{v})$, sažgati $(169 \mathrm{v})$, pravadnici (171r), edan (171r), kadi (170r), zali (168v), vazme (168v). ${ }^{22}$

Kao i u CVinod \& i u CGrš ima ikavsko-ekavski odraz: diva (167v i drugdje), smi (167v), niko (168r), divice (168r), nadiû se (168r), postilû (168v i drugdje), bižati (168v), poviite (168v), svital (169r i drugdje), vitliomi (169r), misec (169v), slipi (169v), pisni (169v i drugdje), izvidivši (169v), vice (169v), nedilu (170r i drugdje), ispovidati (170r), zapovid (171r), grihov (171r); svet (167v i drugdje); sveĉali $(167 \mathrm{v})$, neverni (167v i drugdje); veru $(168 \mathrm{v})$, zvezdi $(169 \mathrm{v})$, celov (169r i drugdje), sredi (169r), posred (169r), verûि (170r), celiva $(170 \mathrm{v})$, peti $(170 \mathrm{v}$ i drugdje), vsedše $(171 \mathrm{r})$, iscelieši $(171 \mathrm{r})$, razmetati $(171 \mathrm{r})$, cel (171r i drugdje), leto (186r), telo (168v i drugdje). Ekavski odraz zadržava se u predmetku pre-: prede (168r), preleti (168r), gdje CVinod ima priletê $\left(48 r^{\mathrm{a}}\right)$. Zabilježene su i riječi s dvojnim oblicima: sveta (169r) / svita (170v); imiti (171r) / imeli (171r); vik (171r) / veki (171r), no u cjelini uzevši tekst iz CGrš pretežno je ikavski.

${ }_{22}$ Mjesta iz CGrš navode se i označavaju prema izdanju u prilogu ovoga rada. 
U CGrš slovo B upotrebljava se isključivo za glasovnu skupinu ja na početku, u sredini i na kraju riječi: vzneseniê $(167 \mathrm{v})$, hoêše $(167 \mathrm{v})$, poêmši (168r), êkov (169r) itd. U položajima u kojima slovo B u CVinod zastupa pra-

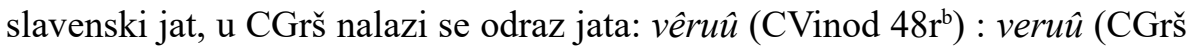
168v), têlo (CVinod 48r $\mathrm{r}^{\mathrm{b}}$ ) : telo (CGrš 168v), cêlb (CVinod 49va) : cel (CGrš 171r) itd. I u CGrš staroslavensko ę prelazi u ja i piše se B: poêmši (168r), êti $(169 \mathrm{v})$, kao što i glas $d$ prelazi u $j$ kod glagola hoditi: hoêše $(167 \mathrm{v})$, vhoêhi (169r).

Dok se u CVinod nalaze slogotvorni glasovi $l$ i $r$ najčešće sa znakom za poluglas: s'ln'ce $\left(48 \mathrm{v}^{\mathrm{a}}\right), m r^{\prime}$ tvih' $\left(48 \mathrm{v}^{\mathrm{a}}\right)$, u CGrš ne samo da nema znaka za poluglas: isplni (170v) nego se javlja i popratni samoglasnik a: salnce (170v), zali (168v). Kao i u CVinod i u CGrš samoglasnik $i$ ispada iza sekundarnog slogotvornog $r$ u riječi prnesite (168r).

U CGrš je jednako kao i u CVinod proveden rotacizam: nigdor' (170r), ne more (170r), ûre (168v), t〈e $\rangle r$ (168r i drugdje). Kao i u CVinod i u CGrš staroslavenska suglasnička skupina $\check{z} d$ prelazi u glas $j$, koji se intervokalno ne bilježi: roena (19r), gospoe (21r) itd.

Kao ni u CVinod ni u CGrš nije u potpunosti provedena druga palatalizacija: mnozi (170r), ali drugih (168v), pravadniki (171r). Iako iza palataliziranog $l$ i $n$, kao i u CVinod, redovito dolazi slovo ఐl: postilû (168v i drugdje), lûdi (169v i drugdje), nedilû (170r i drugdje), ima i slučajeva u kojima se piše slovo 刃: vzlublenoga (168r), nedilu (170r). U CGrš potpuno je provedeno jednačenje po zvučnosti: ispovidati (170r), iscelieši (171r), također i među završnim glasom prijedloga i početnim glasom riječi koja za njim slijedi: is hiže (170r), is tela (170v), is pleĉu (171r). Skupovi dentala i afrikata nisu održani: ocem (170r), oca (171r).

Kod prilagodbe grčkih imena glas koji se u grčkom alfabetu bilježio slovom $\beta$ i dalje se u CGrš, kao i u obama starijim tekstovima, bilježi slovom III u skladu s bizantskim vitacističkim izgovorom toga slova glasom $v$ ili glasom između $b$ i $v$ : vitliomi (169r), piviri (169r), êkov (169r). U prijenosu imena Xepovßí ima mlađe $f$, koje je u čakavskome postalo od $v$ : herufim $(169 \mathrm{v})$. Kod imena

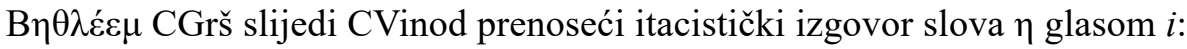

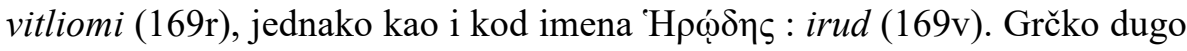
$o$ i u CGrš prelazi u $u$ : simun (169r), j̧imun $(169 \mathrm{v})$, a ponekad i kratko $o$ : ap(usto)l (168v). 
Neka imena prenose se u CGrš jednako kao u CVinod: luka (CVinod 48va) / luka (CGrš 169r); toma (CVinod 48va) / toma (CGrš 169r), neka imena gube znak za poluglas: simun' (CVinod 48va) / simun (CGrš 169r); mar'ko (CVinod 48va) / marko (CGrš 169r); iv (a)nb (CVinod 48 $\mathrm{r}^{\mathrm{b}}$ i drugdje) / ivan (CGrš 168r i drugdje); $p(e) t(a) r b$ (CVinod 48va) / petr (CGrš 168v); $p(a) v(a) l$ ' (CVinod 48va) / pavl (CGrš 169r); êk(o)v' (CVinod 48va) / êkov (CGrš 169r); in'dii (CVinod 48va) / indii (CGrš 169r); er(u)s(oli)mb (CVinod 49va) / erusolim (CGrš 168ri drugdje) itd. Imena koja u CVinod imaju nastavak -êi, prilagođavajući grčki nastavak - $\alpha 10 \zeta /-\varepsilon 10 \varsigma$, u CGrš dobivaju nastavak -ii: an'd(r)êi (CVinod 48v $\mathrm{v}^{\mathrm{a}}$ ) / andrii (CGrš 169r); matii (CGrš 169r); bar 'tolomêi (CVinod 48v $\mathrm{v}^{\mathrm{a}}$ ) / bartolomii (CGrš 169r); i'ûdêi (CVinod 48ra) / iûdii (CGrš 167v, 168v), pored iûdei $(168 \mathrm{v})$.

Grčki glas $p h$, koji se bilježi slovom $\varphi$, prenosi se kao i u CVinod na dva načina ili glasom $f$ : efesi $(169 \mathrm{r})$, šerafim $(169 \mathrm{v})$, ofiên $(171 \mathrm{r})$, ili glasom $p$ : pilip (169r). Grčki glas th, koji se bilježi slovom $\theta$, kao i u CVinod gubi aspiraciju i prenosi se slovom nut: vitliomi (169r), toma (169r), bartolomii (169r) i dr. Slovom IHP u riječi jimun (CGrš 169v) bilježi se čakavska prejotacija po-

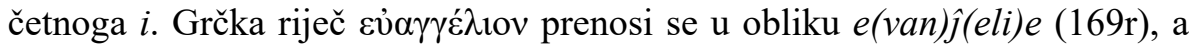
grčka riječ ő $\gamma \gamma \varepsilon \lambda o \varsigma$ prenosi se kao anel (168r i drugdje), bez title kao oznake kraćenja riječi ili s njom: an(j)el (168r i drugdje).

Ime kananêi (CVinod 48va) od Kavavaĩos iskrivljeno je u: ananiê (CGrš 169r), a u obama je tekstovima pogrešno shvaćeno kao zasebno ime, a ne kao sastavni dio imena Šimuna Kananejca. Ime $\Lambda \alpha \beta \delta \alpha v o v ́ \varsigma$ iskrivljeno je u obama tekstovima: al'vana (CVinod 48va) / alvana (CGrš 169r). Kao i u CVinod tako

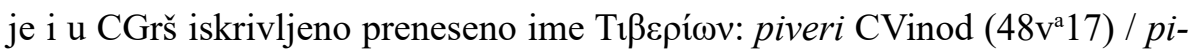

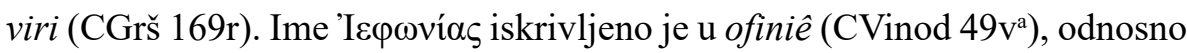

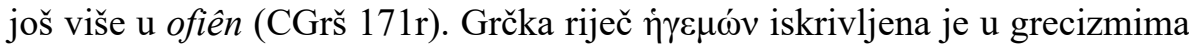
emuns (CVinod 48v') / jimun (CGrš 169v).

Pridjev iz FgTrans i CVinod u CGrš zamijenjen je imenicom: vb alek'sandrbscêem' gradê (FgTrans 2c) : v leksan'dr'skom' gradu (CVinod 48va) : va aleksandrii gradu (CGrš 169r), što je najbliže grčkomu izvorniku \&̀v

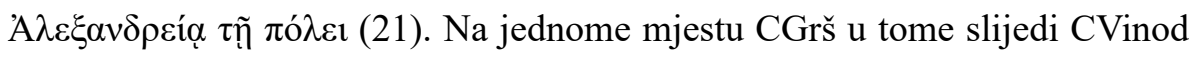

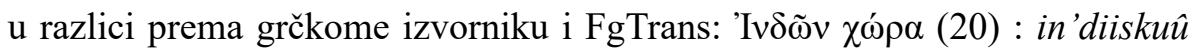
stranu (FgTrans 2b) : v in'dii (CVinod 48v $)$ : v indii (CGrš 169r). 


\subsubsection{Morfologija}

U deklinaciji imenica potvrđeni su mnogi arhaični staroslavenski oblici, koji najčešće supostoje uz mlađe čakavske oblike.

U obama tekstovima nalaze se arhaični oblici imenica muškoga roda. Lokativ jednine na -ê u CVinod imaju sljedeće imenice: gradê $\left(48 \mathrm{v}^{\mathrm{a}}\right)$, epesê $\left(48 \mathrm{v}^{\mathrm{a}}\right)$, er $(u)$ s(oli)mê $\left(48 \mathrm{v}^{\mathrm{a}}\right)$, vitleomê $\left(48 \mathrm{v}^{\mathrm{b}}\right)$, sv(ê) tê $\left(48 \mathrm{r}^{\mathrm{a}}\right)$, rimê $\left(48 \mathrm{v}^{\mathrm{a}}\right)$, na $-e$ : $\operatorname{vrt}(a)$ pe $\left(49 \mathrm{r}^{\mathrm{a}}\right)$, a na $-i$ : časi $\left(49 \mathrm{v}^{\mathrm{a}}\right), k r i z ̌ i ~\left(48 \mathrm{r}^{\mathrm{b}}\right)$, uz jedan primjer mlađega oblika na $-u$ : gradu $\left(48 \mathrm{v}^{\mathrm{a}}\right)$. U CGrš lokativ na $-i$ imaju sljedeće imenice: grobi $(167 \mathrm{v}), s(v e \hat{)})$ ti (168r), križi (168v), efesi (169r), gradi (169r), pored gradu (169r, 170r), rimi (169r), piviri (169r), erusolimi (169r), mori (169r), vitliomi (169r), časi (171r, pored času (171r). U CVinod pojavljuje se i arhaični oblik imenice muškoga roda $u$-deklinacije u vokativu: sinu $\left(48 \mathrm{r}^{\mathrm{a}}, 49 \mathrm{r}^{\mathrm{a}}\right)$, dočim se u CGrš pored oblika sinu (170r, 170v) nalazi i mlađi oblik sine (168r, 168v). Imenice muškoga roda $i$-deklinacije imaju u CVinod vokativ jednine na -i: $g($ ospod $) i\left(48 \mathrm{r}^{\mathrm{a}}\right)$.

Imenice ženskoga roda $a$-deklinacije ponegdje imaju genitiv jednine na $-i$ : $d(\hat{e}) v i\left(C V i n o d 49 \mathrm{v}^{\mathrm{a}}\right)$, divi (CGrš 170v). Imenice ženskoga roda ja-deklinacije imaju stariji oblik dativa jednine na -ei: gospoei (CVinod 48rb) i mlađi na - $i$ : gospoi $\left(\mathrm{CVinod} 48 \mathrm{v}^{\mathrm{b}}\right.$ ). Imenice ženskoga roda $r$-deklinacije imaju dativ jednine na -eri: materi $\left(48 \mathrm{r}^{\mathrm{b}}, 49 \mathrm{r}^{\mathrm{a}}\right)$. Vokativ jednine ženskoga roda u obama tekstovima ima isti nastavak -e: $m(a)$ rie (CVinod $48 \mathrm{r}^{\mathrm{a}}, 48 \mathrm{v}^{\mathrm{b}}$ ) / marie (CGrš $168 \mathrm{r}, 168 \mathrm{v}, 170 \mathrm{v})$, gospoe (CGrš 168r, 170r, 170v). Instrumental jednine ima nastavak -u: silu (CVinod 49ra), ruku (CVinod 49rb), slavu CGrš (168v), postilû (CGrš 168v).

Daljnji su arhaični oblici imenica u genitivu jednine srednjega roda $s$-deklinacije: nebese (CGrš $168 \mathrm{v}$ ), lokativu jednine srednjega roda u obama tekstovima na -i: vskr'sen'i (CVinod 48ra) / vskrišeni (CGrš 168r) i u instrumentalu jednine srednjega roda $n$-deklinacije: imenem (CGrš 171 r).

Nominativ množine imenica muškoga roda $u$-deklinacije ima nastavak -e: židove (CVinod 49v $\left.\mathrm{v}^{\mathrm{b}}, 49 \mathrm{r}^{\mathrm{a}}\right)$ / CGrš $(169 \mathrm{v}, 170 \mathrm{r})$. Nominativ množine ženskoga roda u obama tekstovima ima nastavak $-i$ : sili $\left(\right.$ CVinod $\left.49 \mathrm{r}^{\mathrm{b}}, 49 \mathrm{v}^{\mathrm{a}}\right)$ / sili (CGrš $170 \mathrm{v})$, zvezdi $(169 \mathrm{v})$.

Genitiv množine svih triju rodova u CVinod je na $-\varnothing: n(e) b(e) s b\left(48 \mathrm{r}^{\mathrm{a}}\right.$,

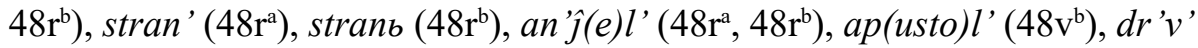
$\left(49 \mathrm{r}^{\mathrm{a}}\right)$, herovim ' $\left(49 \mathrm{v}^{\mathrm{a}}\right)$, serapim' $\left(49 \mathrm{v}^{\mathrm{a}}\right)$, a u CGrš na -ø: krst (i)ên $(167 \mathrm{v})$, stran $(168 \mathrm{r})$, anel $(168 \mathrm{v})$, nebes $(168 \mathrm{v})$, herufim $(169 \mathrm{v})$, šerafim $(169 \mathrm{v})$, ap (usto)l $(169 \mathrm{v}), d r v(169 \mathrm{v}), v i k(171 \mathrm{r})$, a samo na jednom mjestu mlađi čakavski genitiv množine na -ov: grihov (171r). 
U dativu množine muškoga roda javlja se nastavak -omb: ap(usto)l(o)mb (CVinod 48r ${ }^{\mathrm{b}}$ ), ap(usto)lom (CGrš 168v), a u dativu množine ženskoga roda -em': d'varem '(CVinod 49ra). Dok akuzativ množine muškoga roda u CVinod ima nastavak -i: grêšniki $\left(48 \mathrm{v}^{\mathrm{b}}\right)$, ap $(u s t o) l i\left(48 \mathrm{v}^{\mathrm{b}}\right), v(\hat{e}) k i\left(49 \mathrm{r}^{\mathrm{b}}\right)$, pored mlađega nastavka -e: a(pusto)le $\left(49 \mathrm{r}^{\mathrm{a}}, 49 \mathrm{r}^{\mathrm{b}}\right)$, u CGrš pretežno ima -e: grišnike $(169 \mathrm{v})$, ap (usto)le (169v), ali i -i: ap(usto)li (170v), pravadniki (171r).

Lokativ množine muškoga roda u obama tekstovima ima stare nastavke

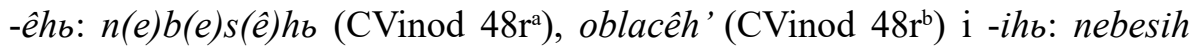
(CGrš 168r), a lokativ množine ženskoga roda -ahb: ž(e)nah' (CVinod 49va)/ ženah (CGrš 171r). Instrumental množine muškoga roda u CGrš ima nastavak $-i$ : razboinici $(169 \mathrm{v})$, apustoli $(169 \mathrm{v})$.

Već u CVinod imenice u akuzativu i nominativu dvojine ženskoga roda imaju dva različita nastavka, stariji nastavak -ê: rucê $\left(48 \mathrm{v}^{\mathrm{b}}, 49 \mathrm{r}^{\mathrm{b}}\right)$ i mlađi nastavak -i: ruci $\left(49 \mathrm{r}^{\mathrm{b}}, 49 \mathrm{v}^{\mathrm{a}}\right)$, a u CGrš samo još mlađi nastavak: ruci $(169 \mathrm{v}, 170 \mathrm{r}$, 170v, 171r). Dok CVinod u akuzativu dvojine srednjega roda ima samo nastavak -ê: kolênê (48ra), u CGrš nalazi se samo mlađi nastavak -i: koleni $(167 \mathrm{v})$. Lokativ dvojine srednjega roda ima nastavak -u: pleĉu $\left(\mathrm{CVinod}_{49 \mathrm{v}}\right)^{\mathrm{a}} /$ pleĉu (CGrš 171r).

Kod pridjeva u genitivu jednine muškoga roda u obama je zbornicima zabilježen samo mlađi oblik na -oga: patomos'koga (CVinod 48r $\left.{ }^{b}\right) /$ patomoskoga (CGrš 168r), n(e)b(e)skoga (CVinod 49va), preslatkoga (CGrš $167 \mathrm{v})$, a također i kratki oblik na -al-ja: svitla $\left(\mathrm{CVinod} 49 \mathrm{v}^{\mathrm{a}}\right), s(v e)$ ta $(\mathrm{CVinod}$ $49 v^{a}$ ) / s(ve) ta (CGrš 171r), božiê (CGrš 167v). Stariji nastavci očuvani su u nominativu jednine ženskoga roda na -aê u CVinod: $s(v e) t a e ̂\left(49 \mathrm{r}^{\mathrm{a}}\right)$, što se gubi u CGrš: sveta (168r i drugdje), zatim u CVinod u kratkom obliku dativa jednine ženskoga roda na -ê: pres(ve) tê $\left(49 \mathrm{r}^{\mathrm{b}}\right)$, nasuprot mlađemu nastavku -oi u CGrš: presvetoi $(170 \mathrm{v})$, također u dužem obliku b(o)žiei $\left(\mathrm{CVinod} 48 \mathrm{v}^{\mathrm{b}}\right)$, kao i božei (CGrš 169r), božiei (CGrš 169v), u akuzativu jednine ženskoga roda na

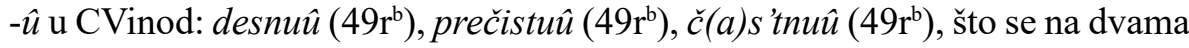

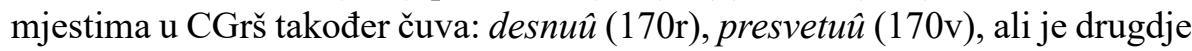
zamijenjeno nastavkom $-u$ : prečistu $(170 \mathrm{v})$, te $\mathrm{u}$ instrumentalu jednine na $-u$ : $b(o) z ̌ i u ̂\left(C V i n o d 49 \mathrm{r}^{\mathrm{a}}\right)$, veliku (CGrš 168v). U dativu jednine srednjega roda oba teksta imaju nastavak -i: g(ospod)ni (CVinod 48ra) / g(ospod)ni (CGrš 168 r). Jedino je na jednome mjestu kod pridjeva u akuzativu jednine srednjega roda CGrš arhaičniji od CVinod jer ima -oe: nebeskoe (167v, 168r), dočim CVinod ima mlađe -o: $n(e) b(e) s k o\left(48 \mathrm{r}^{\mathrm{a}}\right)$, pored starijega svetoe $\left(49 \mathrm{r}^{\mathrm{b}}\right)$. U akuzativu množine muškoga roda CGrš ima nastavak -ie: anelskie $(167 \mathrm{v})$, a isti nastavak oba teksta imaju u nominativu množine ženskoga roda: $n(e) b(e) s k i e$ 
$(C$ Vinod 49va) / nebeskie (CGrš 170v). U akuzativu množine srednjega roda u CVinod nastavak je -aê: s(vê)tlaê (49ra), a u CGrš je mlađi -a: svitla (170r). Akuzativ dvojine ženskoga roda u CVinod ponekad zadržava stari nastavak -ê: presvetê $\left(48 \mathrm{r}^{\mathrm{a}}\right)$, a ponekad dobiva mlađi nastavak $-i$ : prês $(v e) t i\left(49 \mathrm{r}^{\mathrm{b}}\right)$, a u CGrš nastavak je uvijek -i: presveti $(167 \mathrm{v}, 170 \mathrm{v})$, častni (170r).

Kod osobnih zamjenica na jednome mjestu u CVinod potvrđen je stari oblik u nominativu za prvo lice jednine $a z b\left(48 \mathrm{v}^{\mathrm{a}}\right)$, a na svim ostalim mjestima $\mathrm{u}$ obama tekstovima nalazi se mlađi oblik $\hat{e}$. Mlađi oblik lokativa jednine $m n i$ $\left(C V i n o d 49 r^{a}\right)$ nastao je od starijeg oblika mnê. Oblici za treće lice jednine pokazne zamjenice $i, j e, j a$ u genitivu jednine ženskoga roda $e e\left(49 \mathrm{v}^{\mathrm{a}}, 49 \mathrm{v}^{\mathrm{b}}\right)$ i $n e e$ $\left(49 \mathrm{r}^{\mathrm{a}}\right)$, u dativu jednine ženskoga roda ei $\left(48 \mathrm{r}^{\mathrm{a}}, 49 \mathrm{r}^{\mathrm{b}}\right)$ i nei $\left(48 \mathrm{r}^{\mathrm{a}}, 48 \mathrm{v}^{\mathrm{b}}\right)$, očuvani su ne samo u CVinod nego i u CGrš (168v, 170r, 170v). U akuzativu jednine ženskoga roda javlja se oblik $\hat{u}\left(C V i n o d 48 \mathrm{r}^{\mathrm{a}}, 49 \mathrm{r}^{\mathrm{a}}, 49 \mathrm{r}^{\mathrm{b}} / \mathrm{CGrš} 167 \mathrm{v}, 168 \mathrm{r}\right.$, $170 \mathrm{v}, 171 \mathrm{r})$, a u akuzativu množine muškoga roda $e$ (CVinod 49r ${ }^{\mathrm{a}} / \mathrm{CGrš} 169 \mathrm{v}$, 171r), kao i u akuzativu jedinine srednjeg roda (CGrš 171r). Zabilježen je i mlađi oblik u dativu jednine ženskoga roda: noi (CVinod 48r ${ }^{\mathrm{a}}$ / CGrš 168r). U genitivu jednine muškoga roda javlja se oblik ego $\left(\mathrm{CVinod} 49 \mathrm{v}^{\mathrm{a}}\right.$ / CGrš $\left.170 \mathrm{r}\right)$, pored mlađega oblika nega $(\mathrm{CGrš} 167 \mathrm{v})$, u dativu jednine muškoga roda oblik emu $\left(\mathrm{CVinod} 49 \mathrm{r}^{\mathrm{b}}\right)$, u akuzativu jednine muškoga roda $n b\left(\mathrm{CVinod} 48 \mathrm{v}^{\mathrm{a}}\right)$ i nega (CVinod 48ra), a u lokativu jednine muškoga roda nem (CGrš 168r). U CGrš potvrđeni su još mlađi oblici on (170r, 170v), ona (170r), oni (168r, $170 \mathrm{r})$, nih (170v), ih (169v), ne (170v), kojih nema u CVinod. Osobne zamjenice u CGrš, osim u jednom slučaju, dobivaju protetsko $n$-, koje se u CVinod javlja samo na jednome mjestu: nee $\left(49 \mathrm{r}^{\mathrm{a}}\right)$. Osobna zamjenica vi u CGrš u instrumentalu množine ima stariji nastavak -i: vami (169r).

Stara odnosna zamjenica kyi, kaê, koe dolazi u CVinod i CGrš redovito u čakavskim oblicima, nastalim stezanjem samoglasnika nakon ispadanja intervokalnoga $j$ : $k i$ (49 $\mathrm{v}^{\mathrm{a}}$ i drugdje) / $k i$ (CGrš 168r i drugdje), kom' (CVinod 48r ${ }^{\mathrm{b}}$ ) / kom (CGrš 168v), kih' (CVinod 48r $\left.{ }^{\mathrm{b}}\right), k a\left(\mathrm{CVinod} 49 \mathrm{r}^{\mathrm{b}}\right), k u\left(\mathrm{CVinod} 49 \mathrm{r}^{\mathrm{a}}\right.$, $49 \mathrm{v}^{\mathrm{a}}$ ), ke (CVinod 49r $\mathrm{r}^{\mathrm{a}} /$ CGrš 168r, 170r), koi (CGrš 168v, 171r), ko (CGrš 170r).

U genitivu jednine muškoga roda posvojne zamjenice naš u obama se tekstovima javlja samo nastavak -ego: $n(a) \check{s}(e)$ go $\left(\mathrm{CVinod} 48 \mathrm{r}^{\mathrm{a}}, 48 \mathrm{v}^{\mathrm{a}}, 48 \mathrm{v}^{\mathrm{b}}\right) /$ našego (CGrš $169 \mathrm{v}, 170 \mathrm{r})$. U CVinod javlja se stariji oblik u genitivu jednine muškoga roda povratne zamjenice svoego $\left(48 \mathrm{r}^{\mathrm{a}}, 49 \mathrm{r}^{\mathrm{b}}\right)$, pored mlađega svoga $\left(48 r^{a}\right)$, a u CGrš samo svoga $(167 \mathrm{v}, 168 \mathrm{r}, 170 \mathrm{r})$, kao i tvoga (168r). CGrš u dativu jednine muškoga roda ima svoemu (168r), a u dativu jednine ženskoga roda svoei (CGrš 170r), jednako kao i CVinod (49ra). Instrumental jednine 
ženskoga roda u CVinod glasi svôิ (49r $\left.{ }^{\mathrm{b}}\right)$. U CVinod susreće se i stariji nestegnuti oblik u nominativu jednine srednjega roda tvoe $\left(49 \mathrm{r}^{\mathrm{b}}\right)$, a u CGrš u dativu jednine ženskoga roda tvoei $(170 \mathrm{v})$.

Dvojina je i kod zamjenica u obama tekstovima vrlo dobro sačuvana, a susreće se u akuzativu ženskoga i srednjega roda: svoi (CVinod 49r / CGrš $167 \mathrm{v}, 170 \mathrm{r}, 170 \mathrm{v})$.

Zabilježena je i stara pokazna zamjenica $s b$, koja u CVinod u genitivu jednine muškoga roda samo jednom ima nastavak -ego: sego $\left(49 \mathrm{r}^{\mathrm{b}}\right)$, dočim na svim ostalim mjestima dolazi mlađi nastavak -ega: sega (48ra i drugdje). U CGrš zabilježen je samo mlađi oblik: sega (167v i drugdje). U lokativu jednine muškoga roda CVinod ima znak za poluglas: semb $\left(48 r^{a}\right)$, koji se u CGrš gubi: sem (168r).

Zamjenički pridjev vbsb, vbsa, vbse susreće se u lokativu jednine muškoga roda vs(e)m' (CVinod 48ra) / vsem (CGrš 170r), instrumentalu jednine srednjega roda $v s(\hat{e}) m b\left(C V i n o d 49 \mathrm{r}^{\mathrm{a}}\right)$, u nominativu množine muškoga roda $v s i$ (CVinod 48r $\left.\mathrm{r}^{\mathrm{a}}, 48 \mathrm{r}^{\mathrm{b}}, 48 \mathrm{v}^{\mathrm{a}}, 49 \mathrm{r}^{\mathrm{a}}\right)$, genitivu množine $v^{\prime} \operatorname{sih}^{\prime}\left(\mathrm{CVinod} 48 \mathrm{r}^{\mathrm{a}}\right) / v$ sih (CGrš 168r, 170r), dativu množine v's(ê)mb (CVinod 48r $\left.\mathrm{r}^{\mathrm{b}}\right) /$ vsim (CGrš 168v), akuzativu množine ženskog roda vse $\left(\mathrm{CVinod} 49 \mathrm{r}^{\mathrm{b}}\right)$ te u lokativu množine muškoga roda $v \operatorname{sih}$ (CGrš 170r).

Kod brojevnih riječi od starijih oblika zabilježen je jedino nominativ dvojine ženskog roda: obi (CVinod $49 \mathrm{v}^{\mathrm{a}}$ / CGrš $171 \mathrm{r}$ ), a u genitivu množine na -ih: četirih (CGrš 168r) izvorni je oblik zamijenjen duljim pridjevskim nastavkom.

U konjugaciji glagola u prvom licu jednine prezenta u CVinod nalazi se gotovo isključivo stari nastavak $-u \mathrm{i}-\hat{u}$ : nadêu se $\left(48 \mathrm{r}^{\mathrm{a}}\right)$, vêrûे $\left(48 \mathrm{r}^{\mathrm{b}}\right)$, êmu $\left(49 \mathrm{r}^{\mathrm{a}}\right)$, klanaû se $\left(49 \mathrm{r}^{\mathrm{b}}\right), u$ ' $^{\prime} r u\left(49 \mathrm{r}^{\mathrm{b}}\right)$, budu $\left(49 \mathrm{r}^{\mathrm{b}}\right)$, a samo na dvama mjestima nastavak -m': sam' $\left(49 \mathrm{r}^{\mathrm{b}}\right)$, imam' $\left(49 \mathrm{v}^{\mathrm{a}}\right)$. Isto je tako i u CGrš: budu (168r), nadiû se $(168 \mathrm{r})$, prošu $(168 \mathrm{v}, 170 \mathrm{v})$, viû $(168 \mathrm{v})$, klanâ̂ se (170r), pored sam (170v) i imam (170r).

$\mathrm{U} C$ Vinod u drugom licu jednine prezenta nema starijeg nastavka $-s ̌ i$, nego samo mlađeg -šs: hoĉeš $\left(49 \mathrm{r}^{\mathrm{a}}\right)$, v'zmešb $\left(48 \mathrm{r}^{\mathrm{b}}\right)$, ost $(a) v l(a) \check{s}^{\prime}\left(48 \mathrm{v}^{\mathrm{b}}\right)$, a u CGrš nalaze se i stariji oblici: vazmeši (CGrš $168 \mathrm{v})$, iscelieši (171r), pored mlađih: hoĉeš (168v), ostavlaš (169v). U trećem licu jednine u CVinod samo je na jednom mjestu nastavak -etb: raduet'se $\left(49 \mathrm{r}^{\mathrm{b}}\right)$, a drugdje je nastavak -e: ne

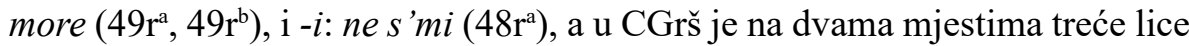
glagola biti u starijem obliku e(stb) (168r), est (171r), a na svim drugim mjestima mlađe $e\left(167 \mathrm{v}\right.$ i drugdje), dočim je u CVinod češće starije $e(s t b)\left(48 \mathrm{r}^{\mathrm{a}} \mathrm{i}\right.$ drugdje), pored mlađega: $e\left(49 \mathrm{r}^{\mathrm{a}}\right)$. U trećem licu množine prezenta oba teksta imaju samo mlađe nastavke: ubô̂ se (CVinod 48rb) / uboe se (CGrš 168v), 


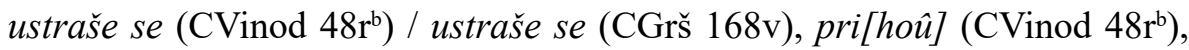

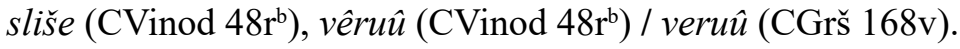

$\mathrm{U}$ aoristu se u obama tekstovima redovito koriste mlađi oblici u svim licima jednine i množine. Kod glagola biti u prvom licu jednine aorista uz oblik bih' $\left(C\right.$ Vinod $\left.48 v^{a}\right)$, posvjedočen je oblik bihi $\left(C V i n o d ~ 48 v^{a}\right)$, koji se susreće i u CGrš (usp. ŠTEFANIĆ 1970: 45), zatim u trećem licu jednine bi (CVinod $\left.48 \mathrm{v}^{\mathrm{b}}, 49 \mathrm{r}^{\mathrm{a}}, 49 \mathrm{v}^{\mathrm{a}}\right)$ i u trećem licu množine biše (CVinod 48ra $)$. U CGrš nalaze se sljedeći oblici: bih (169r), bihi (169r), bi (169v, 170r), biše (168r, 170r). U CVinod susreće se i aorist nesvršenih glagola, kojim se iskazuje ograničena nesvršenost: priziva $\left(49 \mathrm{r}^{\mathrm{b}}\right), z^{\prime} v a\left(49 \mathrm{v}^{\mathrm{a}}\right)$. U obama je tekstovima očuvan i aorist $\mathrm{u}$ trećem licu dvojine: pridosta (CVinod 49va $)$, otpadosta (CGrš 171r).

Imperfekti su dobro očuvani u obama tekstovima: bêhu $\left(48 \mathrm{r}^{\mathrm{a}}\right.$, bihu 49ra $\left.\mathrm{r}^{\mathrm{a}}\right)$ : bihu (167v, 170r). U CGrš prvo lice jednine imperfekta ima nastavak -ahi: vhoêhi $(169 \mathrm{v})$, poslušahi $(169 \mathrm{v})$, prodihovahi $(169 \mathrm{v})$, a ne -ah: hoêhb (CVinod 48r ${ }^{\mathrm{b}}$ ) (usp. ŠTEFANIĆ 1970: 45). Treće lice dvojine imperfekta stahota iz CVinod $\left(48 v^{b}\right)$ u CGrš zamijenjeno je trećim licem množine imperfekta stahu $(169 \mathrm{v})$.

Perfekt se u obama tekstovima tvori od drugoga aktivnog participa preterita i prezenta pomoćnoga glagola biti: e priêla $\left(\mathrm{CVinod} 49 \mathrm{v}^{\mathrm{a}}\right)$, e rodila $(\mathrm{CGrš}$ 170r). Pluskvamperfekt se u obama tekstovima tvori od drugoga aktivnog participa preterita i imperfekta glagola biti: bêhu učinili $\left(\right.$ CVinod $\left.48 \mathrm{r}^{\mathrm{a}}\right)$ / bihu ... učinili (CGrš 167v). Na nekim mjestima gdje CVinod ima aorist, CGrš ima pluskvamperfekt: sveĉa (CVinod 48v') : bihu sveĉali (CGrš 167v); nabraše (CVinod 49ra) : bihu sabrali (CGrš 169v).

Futur prvi izriče se u obama tekstovima prezentom glagola hotêti i infinitivom: hoĉe vzeti (CVinod 48ra ) / CGrš (168r), hoĉeš uslišati (CVinod 48r $\mathrm{r}^{\mathrm{b}}$ ) / hoĉeš slišati (CGrš 168r), hoĉeš poiti (CVinod 48rb) / hoĉeš poiti (CGrš $168 \mathrm{v})$, hote slišati $(168 \mathrm{v})$, hote bižati $(168 \mathrm{v})$, oce priti $\left(\mathrm{CVinod} 48 \mathrm{r}^{\mathrm{b}}\right) /$ hoce priti (CGrš 168v), hoĉe se prestaviti (CVinod 48v a C Crš 169r), hoĉeš '... biti (CVinod 49ra) / hoĉe biti (CGrš 170r), hoĉe priti (CVinod 49v / CGrš 170r), hoce poiti (CVinod 49ra $\left.49 \mathrm{r}^{\mathrm{b}} / \mathrm{CGrš} 170 \mathrm{v}\right)$, zatim svršenim prezentom glagola biti i infinitivom: budu se veseliti (CVinod 48r $\mathrm{r}^{\mathrm{a}}$ / CGrš 168r) i prezentom svršenih i dvovidnih glagola: ležu, umru (CVinod 48r / CGrš 168v), v'zmešb (CVinod 48r ${ }^{\mathrm{b}}$ ) / vazmeši (CGrš 168v).

U imperativu prevladavaju jednostavni ili sintetički oblici u drugom licu jednine na -i: radui se (CVinod 48r ${ }^{\mathrm{a}}$ / CGrš 168v i drugdje), usliši (CGrš 168r), pošlli (CVinod 48ra) / pošli (CGrš 168r i drugdje), stvori (CVinod 48r ${ }^{\mathrm{b}} / \mathrm{CGrš}$

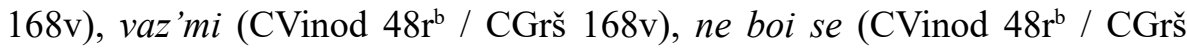


168v), poi (CVinod 48v $v^{\mathrm{a}}$ / CGrš 169r), poidi (CGrš 169r), idi (CVinod 48v

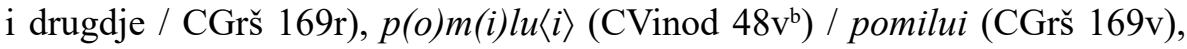
vêrui $\left(\mathrm{CVinod} 49 \mathrm{r}^{\mathrm{a}}\right) /$ verui $(\mathrm{CGrš} 170 \mathrm{r})$, ne skr'bi $\left(\mathrm{CVinod} 49 \mathrm{v}^{\mathrm{a}}\right)$, veseli se (CVinod 49r / CGrš 168r), položi (CVinod 49r $\mathrm{r}^{\mathrm{a}} /$ CGrš 170r), bl(agoslo)vi (CVinod 49r $\mathrm{r}^{\mathrm{b}}$ i drugdje) / blagoslovi (170r), primi (CVinod 49r / CGrš 170v), budi (CVinod 49r / CGrš 170v), počni (CVinod 49r / CGrš 170v, zatim u drugom licu množine na -te: pr'nesête (CVinod 48r / 168r), poidite (CVinod $48 \mathrm{r}^{\mathrm{b}} /$ poite $\left.168 \mathrm{v}\right)$, poveite $\left(\mathrm{CVinod} 48 \mathrm{r}^{\mathrm{b}}\right)$ / poviite (CGrš $\left.168 \mathrm{v}\right)$, u trećem licu jednine, koji je izjednačen s drugim lice jednine, na -i, jednako kao i u staroslavenskom jeziku: pridi (CVinod 48r ${ }^{\mathrm{b}}$ / pridi CGrš $168 \mathrm{v}$ ), verui (CGrš 170r), budi (CGrš 171r). Potvrđen je i složeni ili analitički oblik imperativa za treće lice jednine i množine s veznikom $d a$ i indikativom prezenta, češće u CVinod:

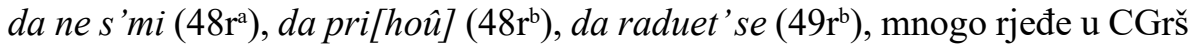
da ... pomilûe (171r), a u CGrš analitički imperativ u trećem licu jednine $\mathrm{s}$ oblikom za drugo lice jednine: da iscelieši (171r).

Od glagolskih načina potvrđen je još i kondicional prvi s veznikom $d a$ za izricanje želje i namjere: da bi $\hat{u}$ vzel' i prestavilb $\left(C V i n o d ~ 48 r^{a}\right) / d a$ bi $\hat{u}$ g(ospo)din b(og) vzel (CGrš 167v); da bi mogal' (CVinod 49va) / da bi mogal (CGrš 171r).

Kod participa su najčešći oblici aktivnog participa prezenta, koji samo u CVinod katkad imaju stare nastavke prema staroslavenskoj paradigmi, npr. u nominativu jednine muškoga i srednjega roda -e: poslušae $\left(48 \mathrm{v}^{\mathrm{a}}\right)$, propovêdae $\left(48 \mathrm{v}^{\mathrm{a}}\right)$, nose $\left(49 \mathrm{v}^{\mathrm{b}}\right)$, hode $\left(48 \mathrm{r}^{\mathrm{a}}, 49 \mathrm{v}^{\mathrm{a}}\right)$, a većinom imaju mlađe nastavke, i to ponajviše -ci $i$, te su postali glagolski prilozi i nemaju sklonidbu, kako u CVinod: poklanaûci $\left(48 \mathrm{r}^{\mathrm{a}}\right)$, pozirâ̂ci $i\left(48 \mathrm{r}^{\mathrm{a}}\right), d r^{\prime}$ 'žeci $\left(48 \mathrm{r}^{\mathrm{a}}\right)$, videĉi $\left(48 \mathrm{r}^{\mathrm{a}}\right)$, govoreĉi $\left(48 \mathrm{r}^{\mathrm{b}}\right)$, gredoĉi $\left(48 \mathrm{v}^{\mathrm{b}}\right)$, hoteĉi $\left(49 \mathrm{r}^{\mathrm{a}}\right)$, držeĉi $\left(49 \mathrm{r}^{\mathrm{b}}\right)$, tako i u CGrš: preklanaûci $(167 \mathrm{v})$, pozirâ̂ci $i(168 \mathrm{r})$, videĉi $(168 \mathrm{r})$, greduĉi $(169 \mathrm{v})$, hoteĉi $(169 \mathrm{v})$, držiĉi (!) (170r), čineĉi (171r), kaûci se (171r), gdje nema drugih oblika osim na jednom mjestu particip s nastavkom - $\hat{c} e$ : govoreĉe $(169 \mathrm{v})$, koji dolazi uz imenicu u nominativu množine i također već poprima priloško značenje. Stoga participi na $-\hat{c} i$ idu ne samo uz imenice u nominativu jednine i množine ženskoga roda nego i uz imenice u nominativu jednine muškoga roda.

Prvi aktivni particip preterita javlja se u nominativu jednine ženskoga roda na -bšil-ši: poêm 'ši (CVinod 48ra) / poêmši (CGrš 168r), i na -vbšil-vši: slišav'ši (CVinod 48ra) / slišavši (CGrš 168r), izvidivši (CGrš 169v), te u nominativu jednine muškoga roda na -vb: obrativ'se (CVinod 49rb), i ni u kojem drugom padežu, te se ponaša poput glagolskog priloga. Osim u nominativu jednine taj se particip javlja još samo u nominativu množine muškoga roda na 
-vbše/-vše: vidêv'še (CVinod 48v'), slišavše (CGrš 170r), i -bšel-še: vsed'še (CVinod 48r $\left.{ }^{\mathrm{b}}, 48 \mathrm{v}^{\mathrm{a}}\right)$ / vsedše (CGrš 168v, 171r).

Pasivni particip preterita služi u tvorbi pasivnog prezenta: bl(agoslove)na

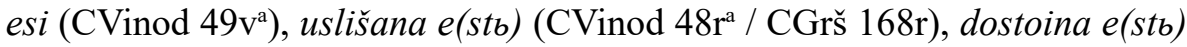
(CVinod 49va), e roen' (CVinod 49ra), e vznesena (CGrš 167v), zatim pasivnog aorista: bi vznesena (CGrš 170r), spaseni biše (CGrš 170r), i pasivnog futura drugog: budu pros 'lavlena (CVinod 49r'), hocešs' sp(a)s(e)nb biti (CVinod 49ra). U CGrš javlja se i u atributnoj upotrebi: vzlublenoga (168r), pozdravlena (170r).

Prijedlog $v b$ u CVinod očuvan je kao samostalna riječ u tom obliku samo na jednome mjestu $\left(48 \mathrm{r}^{\mathrm{a}}\right)$, a na svim ostalima nalazi se $v\left(48 \mathrm{r}^{\mathrm{a}}\right.$ i drugdje), $v^{\prime}\left(49 \mathrm{v}^{\mathrm{b}}\right)$ ili vokalizirano $v a\left(48 \mathrm{r}^{\mathrm{a}} \mathrm{i}\right.$ drugdje) te na jednome mjestu prijedlog $u\left(48 \mathrm{v}^{\mathrm{a}}\right)$. U CGrš svugdje je $v$, osim na mjestima 169r, 169r i 171r, gdje se nalazi va. U CVinod kao predmetak u izvedenicama redovito se čuva $v z-/ v s-:$ vzel' $\left(48 \mathrm{r}^{\mathrm{a}}\right)$, vzvede $\left(48 \mathrm{r}^{\mathrm{b}}\right)$, vzdviže $\left(49 \mathrm{r}^{\mathrm{b}}\right)$, vshiti $\left(48 \mathrm{v}^{\mathrm{a}}\right)$, vspêše $\left(49 \mathrm{v}^{\mathrm{a}}\right)$ i v'z-: v'zmešs $\left(48 \mathrm{r}^{\mathrm{b}}\right)$, $v^{\prime} z d a h n u\left(49 \mathrm{r}^{\mathrm{b}}\right), v^{\prime} z n e s e\left(49 \mathrm{v}^{\mathrm{b}}\right)$, a samo se na dvama mjestima poluglas vokalizira kao va: vaz'mi $\left(48 \mathrm{r}^{\mathrm{b}}\right)$, važ' 'gati $\left(48 \mathrm{r}^{\mathrm{b}}\right)$. U CGrš predmetak $v z$-/vs- također je dobro sačuvan: vzneseniê $(167 \mathrm{v})$, vznesena $(167 \mathrm{v}$ i drugdje), vzeti $(168 \mathrm{r})$, vzlublenoga (168r), vze (169r i drugdje), vzdviže (169v), vzašstie (170r), vzapiše (170v), vskrišeni (168r), vskrišenie (170r), vsta (168v), vstani (169r), a samo se mjestimice nalazi vokalizirano va-: vazmeši $(168 \mathrm{v})$, vazmi $(168 \mathrm{v})$.

$\mathrm{U}$ obama se tekstovima na istome mjestu javlja prijedlog proti (CVinod $48 \mathrm{r}^{\mathrm{b}}$ / CGrš $168 \mathrm{v}$ ), koji ide s dativom. Mlađi oblik prijedloga od pojavljuje se u CVinod samo jednom na mjestu (48ra $)$, a u CGrš samo na dvama mjestima (168v i 169r), dočim se stariji oblik ot'/ot nalazi na svim ostalim mjestima. CGrš ima prijedlog ob (168r), kojega nema u CVinod. U rečenici postavi me simo pred vami (CGrš 169r) prijedlog pred ne ide s akuzativom, nego s instrumentalom vami. Prijedlozi iz CVinod pojavljuju se u svojim mlađim oblicima u CGrš: okols (CVinod 48v') / ok(o)l' (CVinod 48v') : okolu (CGrš 169v), posredê (CVinod $\left.48 \mathrm{v}^{\mathrm{a}}\right)$ / posredi (CGrš $\left.169 \mathrm{r}\right)$. U CGrš $171 \mathrm{r}$ zabilježen je i prijedlog prez, što je mlađi oblik od bez.

Veznik ter piše se u CVinod na mnogo različitih načina: tere $\left(48 \mathrm{r}^{\mathrm{b}}, 49 \mathrm{v}^{\mathrm{a}}\right) /$ $\operatorname{ter}\left(48 \mathrm{v}^{\mathrm{a}}\right) / \mathrm{t}(e) r b\left(48 \mathrm{r}^{\mathrm{b}}\right) /$ tre $\left(49 \mathrm{r}^{\mathrm{b}} 4\right) /$ tare $\left(49 \mathrm{v}^{\mathrm{a}}\right)$. U CGrš na svim mjestima gdje se pojavljuje ima oblik $t\langle e\rangle r$. U CGrš nalazi se i veznik ere (168v), nere (170v). 


\subsubsection{Sintaksa}

Tragovi starijega slavenskoga predloška obaju zborničkih tekstova vidljivi su i u sintaksi. Primjetni su tako neki sintaktički grecizmi koji imaju svoje porijeklo u prvobitnome prijevodu s grčkoga, primjerice perifrastični izrazi s glagolom činiti u CVinod: pokaên'e činah' $\left(48 \mathrm{v}^{\mathrm{a}}\right), z n(a) m(e) n i e ̂$ se činahu $\left(48 \mathrm{v}^{\mathrm{b}}\right)$, čini sl $(a) v a\left(48 \mathrm{v}^{\mathrm{b}}\right)$, i u CGrš: znamenie ... činaše $(169 \mathrm{v})$, se čini ... veselie $i$... slava $(169 \mathrm{v})$, čast čine $(170 \mathrm{v})$, čineci i zapovid $(171 \mathrm{r})$, te isto takvi izrazi s glagolom tvoriti u CVinod: poče tvoriti m(o)l(i)tvu (48ra $)$ i u CGrš: poče molitvu tvoriti (168r), stvori znameniê (168v), što su sve doslovni pri-

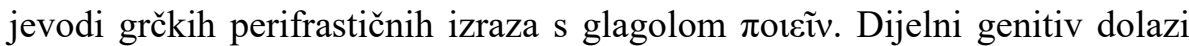

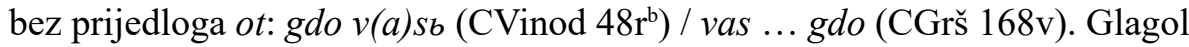
vêrovati u CVinod dolazi s izravnim objektom u akuzativu: $b(\operatorname{og} a)$ verrovati $\left(49 r^{\mathrm{a}}\right)$, što odgovara grčkoj upotrebi glagola $\pi \imath \tau \tau \varepsilon v ́ \varepsilon v v$, pored mlađega: vêrui $v$ $b(\operatorname{og}) a\left(49 \mathrm{r}^{\mathrm{a}}\right)$, a u CGrš isključivo s prijedlogom $v / v a$ : vsi oni ki va te ne verû̂ $(168 \mathrm{v})$, verui v gospoda (170r), počeše verovati v gospoda (171r). Pasivne rečenične konstrukcije $i$ vidêv'še 'židove da se čini sl(a)va b(o)žiê ot ap (usto)l' $\left(48 v^{b}\right)$; i da se čini veliko veselie I velika slava božiê ot ap (usto)l $(169 \mathrm{v}) ;$ zače gospoê v nedilu pozdravlena ot an(j)ela (170r) također su posljedica utjecaja grčke sintakse, u kojoj se upotrebljava glagol u mediju ili pasivu najčešće s prijedlozima vं $\pi$ i a à $\pi_{\text {ó }}$ vršiteljem radnje u genitivu.

Brojne su infinitivne konstrukcije, primjerice infinitiv s pridjevom u imenskom predikatu: dostoina e(stb) priêti $\left(\mathrm{CVinod} 49 \mathrm{v}^{\mathrm{a}}\right)$, dostoina e(stb) poiti $\left(C V i n o d 49 v^{a}\right)$, zatim infinitiv s trećim licem jednine glagola biti: e imiti (CGrš 171r) u značenju 'treba imati' i infinitiv s participom glagola hotêti: hoteĉi $\hat{u}$ s'žgati (CVinod 49ra) / hoteĉi e êti i sažgati ih (CGrš 169v), te s drugim glagolima kao što su početi/počati: počaše b(oga) vêrovati (CVinod 49ra), počni pêti (CVinod 49rb), poče raz'mitati (CVinod 49v $)$, poča m(o)l(i)ti se (CVinod

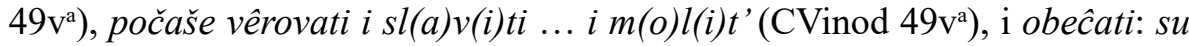
se obeĉali važ'gati (CVinod $\left.48 \mathrm{r}^{\mathrm{b}}\right)$.

Umjesto izravnoga objekta u akuzativu čest je neizravni objekt u genitivu: $p o-$ milui nas nevolnih (CGrš 169v), popali vsih (CGrš 170r), sl(a)ve isp(o)v(ê)dati (CVinod 49ra); hote iûdei slišati prihodeĉ s(ve)tih ap(usto)l s nebese (CGrš $168 \mathrm{v})$.

Sintaksa prijedloga na pokazuje neka arhaična obilježja, kao primjerice u rečenici: mariê bi milostiva na grešnike (CGrš 169v). Umjesto genitiva vremena upotrebljava se prijedložni izraz s prijedlogom na: na niko leto (CGrš 168r), na tom časi (CVinod 49v $\mathrm{v}^{\mathrm{a}}$ / CGrš 171r), na tom času (171r). 
Osobne zamjenice za treće lice u genitivu jednine i množine $u$ obama tekstovima upotrebljavaju se u posvojnom značenju po uzoru na FgTrans i grčki izvornik, u CVinod: ruci ego $\left(49 \mathrm{v}^{\mathrm{a}}\right)$, pleĉi ego $\left(49 \mathrm{v}^{\mathrm{a}}\right)$, odar' nee $\left(49 \mathrm{r}^{\mathrm{a}}\right), d(u) \check{s} u$ ee $\left(49 \mathrm{v}^{\mathrm{b}}\right)$, têlo ee $\left(49 \mathrm{v}^{\mathrm{a}}\right)$, a u CGrš: vzašstie ego $(170 \mathrm{r})$, grob nega $(167 \mathrm{v})$, nih $d u s ̌ a(170 \mathrm{v}), d u s ̌ u ~ . . . n e(170 \mathrm{v})$. Za izricanje posvojnosti u prvom i drugom licu jednine i množine upotrebljavaju se posvojne zamjenice moi (CVinod 48ra i drugdje), tvoi (CVinod 48ra i drugdje), naš’ (CVinod 48ra ) i vaš (CGrš 168v).

\subsubsection{Leksik}

Unutar leksika valja izdvojiti neke arhaizme u CVinod: prestaviti $\left(48 \mathrm{v}^{\mathrm{a}} \mathrm{i}\right.$ drugdje $)^{23}$, nigdore $\left(48 \mathrm{r}^{\mathrm{a}}\right)$, v'spet $\left(48 \mathrm{r}^{\mathrm{a}}\right)$, iudêi $\left(48 \mathrm{r}^{\mathrm{b}}\right), n(i)$ ne $\left(48 \mathrm{r}^{\mathrm{b}}\right)$, azb $\left(48 \mathrm{v}^{\mathrm{a}}\right)$,

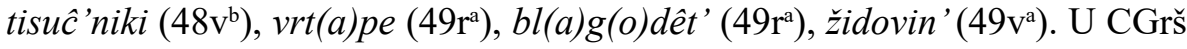
su arhaizmi malobrojniji: nigdore $(167 \mathrm{v})$, prestavili (168r), židovin (171r), ali u njemu se nalazi vrlo stara riječ blagouhaniê (170v), što je još doslovniji

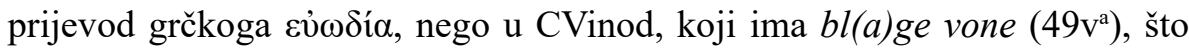
je slično u FgTrans 3d: vone blage. U CGrš zabilježene su neke mlađe riječi: vikuvični (167v), prodikovahi (169r) itd. No i u CVinod, koji je jezično arhaičniji od CGrš, susreću se neke čakavske riječi, primjerice glagol praviti u značenju 'govoriti', koji se nalazi izvan same pripovijesti u svojevrsnom ko-

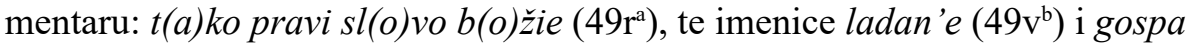
$\left(48 \mathrm{r}^{\mathrm{a}}\right)$, kojih nema u CGrš.

Pored pokazne zamjenice $s b$ u CVinod javlja se i pokazna zamjenica $t a, t a$, to u nominativu jednine srednjega roda to $\left(49 \mathrm{v}^{\mathrm{a}}\right)$ i u lokativu jednine muškog roda tom' $\left(49 \mathrm{v}^{\mathrm{a}}\right)$. Zabilježena je i zamjenica ov, ova, ovo u obama tekstovima: ovim '(CVinod 48r'), ovu (CGrš 168v), ova (CGrš 169v). Kod upitnih zamjenica javlja se mlađi oblik zač' (CVinod 49ra / zač (CGrš 170v), i to u značenju 'jer, zbog toga što', ali i stariji gdo (CVinod 48r $\left.{ }^{\mathrm{b}} / \mathrm{CGrš} 168 \mathrm{v}\right)$. Prema gdo javlja se u CVinod nigdore (48ra $)$ i nig'dore $\left(49 \mathrm{r}^{\mathrm{a}}\right)$, a u CGrš nigdore $(167 \mathrm{v}) \mathrm{i}$ nigdor (170r).

Razlike u leksiku između dvaju zborničkih tekstova također pokazuju mlađe jezično stanje teksta iz CGrš: ovim' od'rom' (CVinod 48rb) : ovu postilu (CGrš 168v); važ'gati (CVinod 48r') : sažgati (CGrš 168v); vzvede se (CVi-

${ }^{23}$ I u drugim hrvatskoglagoljskim brevijarima i zbornicima za blagdan Velike Gospe upotrebljava se riječ prêstavlenie: iznamše bl(a)gd(a)ne prêstavlen'ê ee CPar 154r; zač' e prišlo vrime pokoê moga i moga prestavleniê CŽg 82v; prestavleniê b(ogo)r(odi)ce BrVat $_{5} 148 \mathrm{c}$; prêstavlenie $b\left(\right.$ ogo)r(odi)ce $\mathrm{BrLab}_{1}$ 173a. $\mathrm{U}_{\mathrm{BrN}_{2}} 271 \mathrm{c}$ nalazi se riječ vznesenie. Na ovim podatcima zahvaljujem dr. sc. Marinki Šimić. 
nod 48r $\left.\mathrm{r}^{\mathrm{b}}\right)$ : vsta (CGrš 168v); velikim' (CVinod 48v $\left.\mathrm{v}^{\mathrm{b}}\right)$ : veliem (CGrš $\left.169 \mathrm{v}\right)$, premda i CVinod ima velim' $\left(49 \mathrm{v}^{\mathrm{a}}\right) ; v^{\prime} z d a h n u\left(\mathrm{CVinod} 49 \mathrm{r}^{\mathrm{b}}\right)$ : izdahnu (CGrš 170v); priê (CVinod 49rb) : vze (CGrš 170v); hram (CVinod 49ra $\left.49 \mathrm{r}^{\mathrm{a}}\right)$ : dom (CGrš 169v, 170r) i hiža (170r). Obratno, u CGrš nalazi se riječ celov (169r), koja je bliža staroslavenskomu cêlovanie (FgTrans 2a), nego pozdrav'lenie (CVinod 48va). Još neke riječi koje CGrš ima, a CVinod ih nema: vzneseniê $(167 \mathrm{v})$, vznesena $(167 \mathrm{v}, 171 \mathrm{r})$, krst (i)ên $(167 \mathrm{v})$, kristêninu $(170 \mathrm{v})$, pravadnici (171r), razboinici $(169 \mathrm{v})$ itd. pokazuju da je tekst iz CGrš mlađi.

Sljedeći grecizmi nalaze se u obama tekstovima: an '̧ر(e)l' (CVinod 48r $\mathrm{r}^{\mathrm{b}}$ i drug-

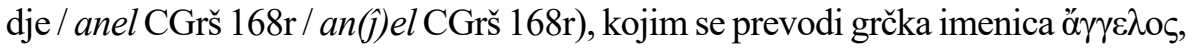
i u kojem se grčko palatalno $g$ bilježi slovom IIP, kao i u e(van)j(eli)e u CGrš 169r, zatim veoma često ap(usto)lb (CVinod 48r ${ }^{\mathrm{b}}$ ) / ap(usto)l (CGrš 168), a od semiti-

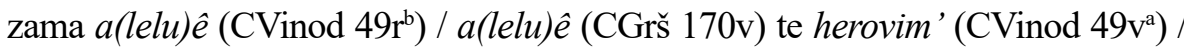
herufim (CGrš 169v) i serapim' (CVinod 49va) / serovimi (!) (CVinod 48v') / šerafim (CGrš 169v). U CGrš javlja se također semitizam amen (171r) bez itacizma.

Unutar leksika u zborničkim se tekstovima susreću mnogi teološki termini

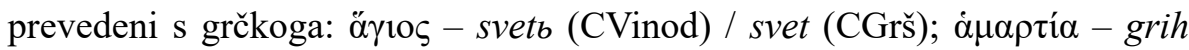
(CGrš); $\dot{\alpha} \mu \alpha \rho \tau \omega \lambda$ ó - grêšnik' (CVinod) / grišnik (CGrš); $\alpha \mu \omega \mu \mathrm{s}$ - neporo-

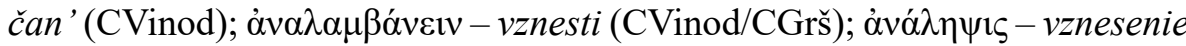

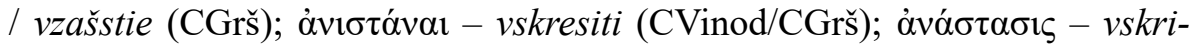

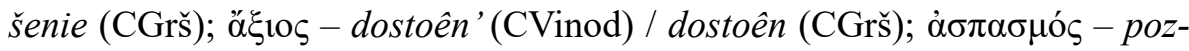

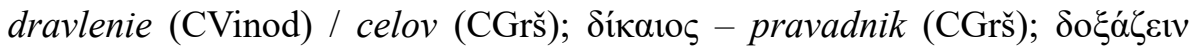

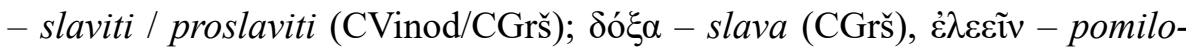

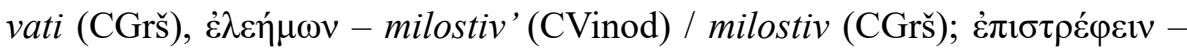

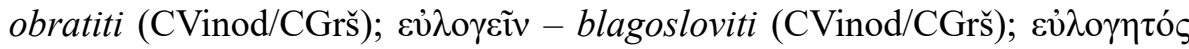

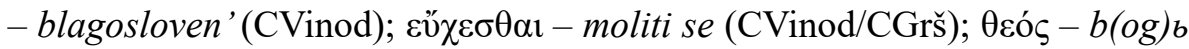

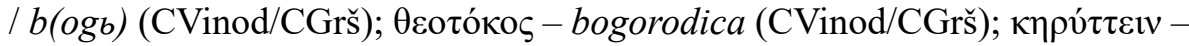

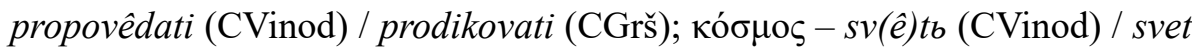

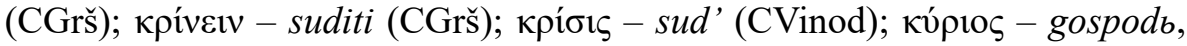
gospodinb (CVinod) / gospod, gospodin (CGrš); кupía - gospa, gospoê / gos-

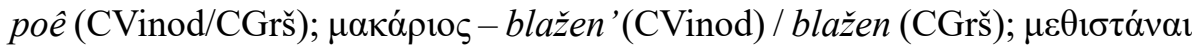

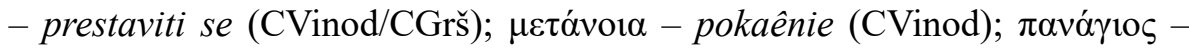

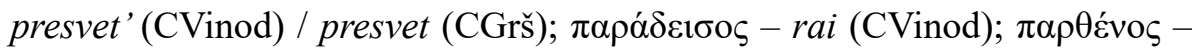

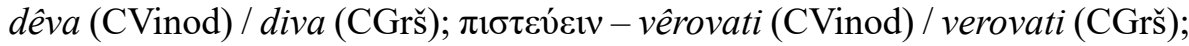

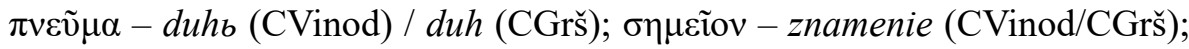

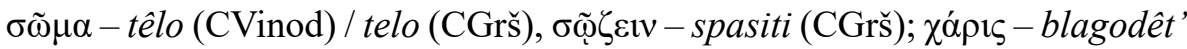

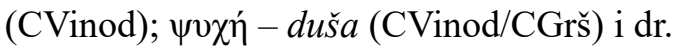




\subsection{Tekstološka analiza}

Oba glagoljska zbornička teksta dijele osnovni sadržaj apokrifa - Marijina molitva na Isusovu grobu, dolazak anđela Gabrijela, koji joj naviješta smrt, čudesan dolazak prvo apostola Ivana, a potom i drugih apostola na oblacima iz raznih krajeva svijeta, što svatko od njih pripovijeda Mariji, dolazak Isusa i svetih u Marijin dom, nevjerni Židovi, Marijina čudesa, njezina smrt i uznesenje - ali među njima postoji i niz sadržajnih razlika.

Dok u CVinod Marija nakon boravka u Jeruzalemu poslije Isusove smrti prima navještenje arkanđela Gabrijela o svojoj skorašnjoj smrti i potom se uz pomoć Duha Svetoga vraća u Betlehem: slišav'ši s(ve)ta m(a)riê te rêči od an 'ر(e)l (!) $i$ vrati se v'spet'va vitleomb grad' $\left(48 \mathrm{r}^{\mathrm{a}}\right)$, dotle se u CGrš Marija čuvši Gabrijelovo navještenje vraća u Jeruzalem, gdje je i umrla: I slišavši diva mariê tu rič' ot' an(j) ela gabriela i vrati se opet'v erusolim' (168r). Očito je u CGrš riječ o sadržajnoj pogreški, koja je mogla biti i namjerna zbog kraćenja teksta, a mogla je nastati i zato što je pisar shvatio da se Marija s Isusova groba, koji se nalazio u Jeruzalemu u blizini Kalvarije, vraća u sam grad Jeruzalem. Iako i tekst iz CGrš po svim ostalim obilježjima nedvojbeno pripada betlehemskoj predaji, prema kojoj se Marija iz Jeruzalema najprije vraća u Betlehem, kamo ju pohode apostoli došavši sa svih strana svijeta, da bi zatim pred Židovima ponovno izbjegla u Jeruzalem, gdje i umire, taj tekst ne govori o tome, nego se sva zbivanja u njemu odvijaju u Jeruzalemu. Marija u početku u Jeruzalemu posjećuje Isusov grob, tamo susreće sve apostole i tamo dočekuje kraj svojega zemaljskog života.

Tekst iz CVinod i u tom je pogledu vjerniji grčkomu izvorniku i starijim slavenskim tekstovima. Upravo je po Marijinu povratku iz Jeruzalema u Betlehem, kamo dolaze apostoli da budu uz nju, dobila naziv i cijela betlehemska predaja teksta. Povratak iz Betlehema u Jeruzalem međutim ni u CVinod nije opisan nego se odmah nakon pokušaja Židova da uhvate Mariju i apostole $u$ Betlehemu i razgovora između Marije i Isusa govori o Marijinoj smrti u Jeruzalemu, što je posljedica skraćivanja teksta. Prema palminoj predaji teksta Marija uopće nije napuštala Jeruzalem.

Oba teksta ispuštaju riječ tiovidê, ime grada iz kojega u FgTrans dolazi apostol Bartolomej, samo što CVinod na tom mjestu ne spominje nikakav grad, a CGrš upotpunjuje tu prazninu spominjući grad Betlehem, što je moguće zato što se svi događaji u CGrš zbivaju u Jeruzalemu, a nije moguće $u$ CVinod zato što se Marija zajedno s apostolima već nalazi u Betlehemu pa Bartolomeja ne treba oblak prenijeti u grad u kojem on već jest. U FgTrans 
Marija dočekuje apostole u Betlehemu, kamo je otišla odmah poslije navještenja smrti, kako stoji i u svim drugim rukopisima te predaje.

U CVinod radnja započinje prvoga dana nakon obljetnice Isusova uskrsnuća: biše pr'vi d(a)nb po v(b)skr 'sen'i g(ospod)ni (CVinod 48ra ), a u CGrš drugoga dana nakon obljetnice uskrsnuća: I biše na niko leto drugi dan po vskrišeni g(ospod)ni (168r).

U CVinod Mariji se obraća apostol Ivan: pride iv(a)nb $d(u) h(o) m b$ s[(ve)timb] s patomos 'koga otoka epesa i r(e)če (48rb), a u CGrš anđeo: I tu anel reče $k$ nei (168r). Apostolima se u CVinod obraća apostol Pavao: $t(e) r b$ imb $r(e) \check{c} e ~ s(v e) t i$ $p(a) v(a) l$ ' (48r $\left.\mathrm{r}^{\mathrm{b}}\right)$, a u CGrš apostol Petar: I reče im s(ve)ti petr (168v). U CVinod naviješta se spas čovjeku koji priziva ime Marijino, a u CGrš spas čovjeku koji priziva ime Isusovo.

Kao mlađi tekst CGrš odlikuje se dodanim elementima kojima je svrha učvrstiti vjeru u Marijino uznesenje i njezinu božansku prirodu. Marija se na više mjesta naziva djevom i izričito se upotrebljavaju riječi: vznesenie $(167 \mathrm{v})$ i vznesena $(167 \mathrm{v}, 170 \mathrm{r}, 171 \mathrm{r})$. Kao poseban oblik štovanja Marije, koji vjerniku donosi spas duše, dodaje se post njoj u čast: post poste (174v). U CGrš redovite su i dopune uz Marijino ime: divo b(ogo)r(odi)ce (168v), $k$ b(la)ženoi divi b(ogo)r(odi)ci marii (168v i drugdje). Marijino božansko majčinstvo i prisnost s Gospodom ističe se sljedećim izrazima: $k$ svomu sinu slatkomu (168v), sinu moi predragi (170r), sina svoga preslatkoga (168r) itd. Osim toga u CGrš dodani su i pogrdni pridjevi pri svakom spomenu Židova: neverni iûdii $(167 \mathrm{v})$, zali židove $(168 \mathrm{v})$, zali i nečisti židove neverni $(169 \mathrm{v})$, hudi židove (169v), kojih nema u CVinod. U CVinod također nema riječi: krst(i)ên (167v), kristêninu (170v), crikvi (169r), koje su unesene u mlađi tekst CGrš.

CGrš sadrži nadopune pojedinih riječi kojih nema u CVinod: kadilnicu zlatu (168r), slnce i misec i zvezdi (169v), s razboinici (169v) itd. Ponekad se dodaje i cijela rečenica: Iz drugih stran bratiû mô̂ i hote bižati iûdii (168v); $k$ svetomu oltaru na službu božiû v crikvi v efesi gradi (169r); I mnozi židove slišavše oni ki bihu v gradu obratiše se na veru i spaseni biše (170r); $i$ tako se poče valati ofiên prez ruku (171r); budi milostiv vsakomu krstêninu ki ime tvoe hvale i moi post poste (170v); I vsi ludi ki vidiše to čudo počeše verovati v gospoda našego is(u)h(rbst)a $i$ v svetu divu mariû $i v$ svetu nedilu (171v) itd. Pri kraju teksta u CGrš nalazi se rečenica koje nema u CVinod, a služi kao svojevrsna uputa za krepostan kršćanski život: I tako e imiti vsakomu krstêninu pravu veru kako su û imeli vsi pravadnici čineĉi zapovid božiû kâ̂ci se grihov svoih da e pomilûe g(ospo)din b(ogb) kako pomiloval vse pravadniki (171r). U CGrš ispuštene su sljedeće rečenice koje se nalaze u 
CVinod: i pridoše vsi ap (usto)li va vitleomb ks(ve)toi m(a) rii m(a)t(e)ri b(o)žiei $\left(48 \mathrm{v}^{\mathrm{a}}, 48 \mathrm{v}^{\mathrm{b}}\right)$; i poslaše tisuĉ'niki ... va vitleom' ... domb g(ospod) a n(a)̌́(e)go is $(u) h(r b s t) a\left(48 v^{b}\right)$. Te su rečenice morale biti ispuštene već i zato što se u njima jasno navodi Betlehem kao mjesto Bogorodičina boravka, a prema CGrš to mjesto je grad Jeruzalem.

Samo je na nekoliko mjesta CGrš bliži FgTrans nego CVinod. Prvo na mjestu gdje se spominje riječ celov: I reče mi duh s(ve)ti Ivane poidi v erusolim grad na celov $k$ svetoi marii materi božei (169r) : hodi vb vitleom'na cêlovanie ee (FgTrans 2a, 2b), dok CVinod umjesto riječi celov ima riječ pozdravl(e)nie: id(u)h's(ve)ti r(e)č(e) mi · idi v'vit'lêomb na pozdravl(e)nie k'm(a)t(e)ri n(a) $\check{s}(e)$ go is $(u) h(r b s t) a\left(48 v^{a}\right)$. Nadalje, uočljive su neke sadržajne razlike među dvama tekstovima po kojima je tekst iz CGrš bliži starijemu tekstu FgTrans. U CGrš spominje se apostol Matej, koji dolazi s mora (premda se ne spominje oluja kao u FgTrans), a u CVinod Matej se uopće ne spominje. U CVinod Jefonija se moli ruci i apostolu Petru, a u CGrš, kao i u grčkom izvorniku, moli se Mariji i apostolu Petru.

Na nekim su mjestima sva tri teksta različita, npr. u CVinod apostol Marko kaže: pokaên'e činah' (48va), a u CGrš: prodikovahi e(van)j(eli)e (169r), dočim u FgTrans 2c kaže: m(o)l(it)vu tvorah[b]. Bartolomej u CGrš iz Betlehema dolazi u Jeruzalem, u CVinod se ne kaže gdje se nalazi, ali dolazi u Betlehem, a jedino se u FgTrans kaže da je u gradu Tebi i da ide u Betlehem. No, oba zbornička teksta povezuje ista pogreška koja se odnosi na apostola Tomu. On naime dolazi iz Indije, gdje je bio kod nekoga trgovca: bih'v in'dii u al'vana kup'ca v polači (CVinod $48 \mathrm{v}^{\mathrm{a}}$ ) / ê bih u alvana kupca v polači v indii (CGrš 169r), što je u FgTrans 2b posve drukčije a sukladno grčkomu izvorniku: Labdan nije trgovac, nego sinb sestri c(êsa)rici. Ta pogreška nedvojbeno upućuje na srodnost između CVinod i CGrš.

U pogledu teološkoga shvaćanja Marijine smrti i uznesenja na nebo dušom i tijelom u CVinod Marijina duša, kada Marija izdahne, izlazi iz tijela i Gospodin ju uzima na nebo: $g(o s p o) d(i) n b$ vze $d(u)$ šu gospoinu s(ve)tims $d(u) h o m b n(a) n(e) b o\left(49 v^{a}\right)$, a apostoli tijelo polažu na odar: a s(ve)ti a (pusto)li vzeše s(ve) to têlo ee i č(a) stno položiše na odar' $\left(49 \mathrm{v}^{\mathrm{a}}\right)$ i zajedno na oblacima svi odlaze u raj: položiše v rai $\left(49 \mathrm{v}^{\mathrm{a}}\right)$, ili, kako se još naziva to mjesto, u $n(e)$ b(e)ska prêstola skroviça $\left(49 \mathrm{r}^{\mathrm{a}}, 49 \mathrm{v}^{\mathrm{b}}\right)$, gdje Gospodin sjedinjuje Marijinu dušu s tijelom i uznosi Mariju i dušom i tijelom $n(a) n(e) b(e)$ sko ladan'e $\left(49 \mathrm{v}^{\mathrm{a}}\right)$. Za razliku od toga u CGrš Isus uzima dušu zajedno s tijelom čim se duša odvoji od tijela: I kada izide presveta duša is tela nee ... tada go(spo)din b(ogb) ponese dušu presvetuû ne s telom duhom s(ve)tim (170v), nema spomena raja, 
ali se nešto kasnije spominju apostoli koji su s Marijinim tijelom poneseni na dvanaest oblaka na nebo. Na kraju teksta u CGrš nema spomena o tome da Isus na nebu sjedinjuje Marijinu dušu i tijelo, nego tekst završava poukom o pravoj vjeri i zaključnom rečenicom da se Marijino uznesenje zbilo tako kako je opisano i da Mariju treba uvijek častiti zajedno sa Svetim Trojstvom. CVinod imenuje mjesto gdje Marija odlazi poslije smrti: $n(e) b(e)$ ska prêstola $\left(49 \mathrm{v}^{\mathrm{a}}\right), n(e) b(e)$ sko ladan'e $\left(49 \mathrm{v}^{\mathrm{b}}\right)$, rai $\left(49 \mathrm{v}^{\mathrm{a}}\right)$, čega nema u CGrš. Jedino mjesto koje se spominje u CGrš su svitla skrovica (170r), što se nalazi i u CVinod $\left(49 r^{\mathrm{a}}, 49 \mathrm{v}^{\mathrm{b}}\right)$ i u FgTrans (3a).

Pri spomenu nedjelje, koja je za kršćane poseban dan u tjednu, u CVinod navode se i glavni kršćanski blagdani koji su vezani za Mariju: Blagovijest/ Navještenje, Božić, Uskrs i Sudnji dan, čime se naglašava Marijina uloga u povijesti spasenja. Ti isti blagdani ponavljaju se i u CGrš, ali im se pridodaju još dva: Isusovo uzašašće na nebo i Marijino uznesenje, čime je uznesenje kao blagdan spomenuto prije nego što se u radnji apokrifa sam taj događaj zaista i zbio.

\section{USPOREDNA JEZIKOSLOVNA I TEKSTOLOŠKA ANALIZA APOKRIFA USNUĆE BOGORODICE IZ FATEVIĆEVA ZBORNIKA I ZBORNIKA VARIA VARIORUM 39}

\subsection{Rukopisna predaja, predlošci i izdanja}

Tekstovi apokrifa iz Fatevićeva zbornika i zbornika Codex Varia Variorum 39 pripadaju palminoj predaji, koja je u hrvatsku srednjovjekovnu književnost dospjela kao slavenski prijevod latinskoga prijevoda s grčkoga, koji se proširio na latinskom Zapadu. Taj latinski prijevod, poznat pod nazivom Transitus $B$ (Liber de transitu auctore Pseudo-Melitone, CANT 111, BHL 5351-5352a; izd. PG 5, 1231-1240), nastao je vjerojatno krajem 5. stoljeća kao prijevod izgubljenoga izvornoga Pseudo-Melitonova grčkoga teksta, koji je sastavljen kao sažetak tekstova koji se svode na pretpostavljeni izgubljeni grčki izvornik iz 4. stoljeća, koji je sačuvan samo u etiopskom prijevodu s kraja 5. stoljeća i početka 6. stoljeća pod naslovom Liber Requiei Mariae (izd. ARRAS 1973). Izdanje Pseudo-Melitonova teksta priredio je Constantin von Tischendorf (TISCHENDORF 1866: 124-136). Tekst je izdan također i u Patrologia Graeca (PG 5, 1231-1240). Drugu verziju Pseudo-Melitonova teksta izdala je Monika Haibach-Reinisch (HAIBACH-REINISCH 1962). 
Apokrif o Bogorodičinoj smrti u Fatevićevu zborniku (CFat) uklopljen je u propovijed za blagdan Marijina uznesenja: Na Vznesene Divice Marie kapitul (ff. 20r-21r), a počinje riječima: a kako e ona bila umrla s(ve)to pismo nam skazue prilika šti se ... (20v), i završava riječima: $i$ vsta i poide $k$ nemu kako vzlublenomu sinu svoemu i tako š nim na nebo sa slavom preide (21r). Propovijed se osim od apokrifnoga dijela sastoji još i od raznih pohvala Mariji, uputa kako njegovati njezinu pobožnost, isticanja njezine posebnosti u odnosu na apostole, prve kršćanske mučenike, ispovjednike i druge djevice, zato što ih svetošću, milosrđem i dobrotom sve nadvisuje, te od opisa njezinih čuda. U skladu s govornim stilom propovijedi u tekstu iz CFat česte su poredbe, ponavljanja i metafore. Na pojedinim mjestima ističe se ispravna kršćanska vjera npr. u Sveto Trojstvo i u uznesenje Marijino, što je popraćeno pozivanjem na crkvene autoritete i propovjednike kao što su sv. Bernard i sv. Anselm. Ponegdje se navodi i sadržaj drugih Marijinih legendi, onih o njezinu djetinjstvu i o viđenju njezina uznesenja koje je imala sv. Elizabeta. Susreću se navodi iz Biblije, upute na starozavjetne knjige, osobito psalme, spomen starozavjetnih likova, kao primjerice kralja Salomona itd., što služi povezivanju Staroga zavjeta i Novoga zavjeta, a početnom tvrdnjom da apokrifni tekst pripada Novomu zavjetu nastoje se izbrisati granice između kanonskih evanđelja i apokrifa. Na samom početku Fatevićeva zbornika, na f. 1r-1v, sačuvan je završetak jedne propovijedi, koji govori o tome kako je Djevica Marija uznesena i na nebu dočekana. ${ }^{24}$ Prvi dio toga teksta, u kojem je riječ o samom činu uznesenja, o molitvama apostola i pratnji raspjevanih anđela i djevica, sadržajno se djelomice poklapa s dužim tekstom iz CFat i s tekstom iz CVar, dočim se njegov drugi dio, kada Bogorodicu na nebu dočekuju i ponaosob joj se obraćaju Otac, Sin i Duh Sveti, ne nalazi ni u jednom od dvaju spomenutih tekstova.

Tekst iz zbornika Varia Variorum 39 (CVar) naslovljen je Nadan vfisciafchia. D. M. nanebessa - Vsuifcenie Priciste Suete Dieue Marie kada bij vfuisceno. To je zapravo propovijed na dan uznesenja Djevice Marije, tj. na blagdan Velike Gospe 15. kolovoza, unutar koje se odmah na početku nalazi apokrif o Marijinoj smrti i uznesenju na nebo (KARÁSEK 1913: 3-8), a zatim slijedi još viđenje Marijina uznesenja koje je doživjela sv. Elizabeta kao i opis

${ }^{24}$ I u tu je propovijed vjerojatno bio uklopljen apokrif o usnuću Bogorodice koji pripada palminoj predaji. Završni opis Bogorodičina dočeka na nebu nakon uznesenja, sadržan u sačuvanom ulomku, ne nalazi se ni u jednom od zborničkih tekstova obrađenih u ovome radu. Dvojbeno je pripada li i taj dio propovijedi apokrifu o usnuću Bogorodice jer ne odgovara sadržaju latinskoga izvornika Transitus B (TISCHENDORF 1866: 124-136). Zato jezikoslovna i tekstološka obrada toga teksta nije uključena u ovaj rad. 
šest Marijinih čuda, ${ }^{25}$ kojima spašava one koji ju štuju, koji se utječu njezinu zagovoru, zazivaju njezino ime i mole njezine molitve.

Usporedba hrvatskoga teksta s latinskim izvornikom Transitus $B$ u Tischendorfovu izdanju pokazuje stanovitu sličnost među njima, ali nije riječ o doslovnom prijevodu s latinskoga, jer su u odnosu na latinski izvornik primjetna velika skraćivanja, dodavanja i drugi postupci prerade teksta. ${ }^{26}$ Mnoštvo talijanizama upućuje na to da hrvatski tekst nije nastao u izravnom prijevodu s latinskoga, nego da je između njih posredovao talijanski prijevod, tj. da je preveden s talijanskoga predloška, koji je već morao biti prerada latinskoga izvornika. Konačan bi odgovor zahtijevao pokušaj utvrđivanja dosad nepoznatoga talijanskog predloška, kao i podrobnu analizu triju tekstova: latinskoga izvornika, talijanskoga prijevoda s latinskoga i hrvatskoga prijevoda s talijanskoga. ${ }^{27}$

CFat je napisan na otoku Ravi i njegov jezik pripada srednjočakavskomu ikavsko-ekavskom dijalektu čakavskoga narječja, a CVar je napisan na štokavskom dubrovačkom jekavsko-ikavskom govoru.

\subsection{Jezikoslovna analiza teksta u CFat}

\subsubsection{Fonologija i grafija}

Znak za poluglas u CFat bilježi se u obliku štapića, a nalazi se samo na nekoliko riječi i to najčešće u skraćenicama: $B($ og)' (19r), č(lovê)k'(20r), Isuh(brst)' (20v i drugdje), Isus' (21r), što je ostatak pisarske tradicije. ${ }^{28} \mathrm{U}$ ostalim riječima kada je u slabom položaju poluglas se dosljedno gubi, a kada je u jakom

${ }^{25}$ U hrvatskoj srednjovjekovnoj književnosti Marijini mirakuli u cjelini su sačuvani u Ivančićevu zborniku, a neki mirakuli iz toga zbornika nalaze se i u CVar: legenda o Mariji Egipatskoj i legenda o židovskom dječaku, obje prvobitno nastale na grčkom jeziku (usp. PETROVIĆ 1977: 20-21).

${ }^{26} \mathrm{Na}$ povezanost hrvatskoga teksta i latinskoga Transitus Mariae $B \mathrm{u}$ Tischendorfovu izdanju upozorava i Karásek u predgovoru svojega izdanja (vidi KARÁSEK 1913: VII).

${ }^{27}$ Usp. PETROVIĆ 1984: 188: »Ovaj izvanredni tematski odabir u rukopisu iz 17. stoljeća, nastao [je] prema znatno starijem predlošku (...) Pitanje pak stranog predloška dubrovačkom legendariju (...) bit će svakako kompleksnije nego što se pretpostavljalo jednostavnim pozivanjem na neki talijanski izvor.«

${ }^{28}$ Mjesta iz Fatevićeva zbornika označavaju se prema izdanju FZ 2016: 212-220. U svojoj transliteraciji glagoljičnoga teksta Grozdana Franov-Živković je sljedeća slova transkribirala: $\boldsymbol{\Psi}=\dot{c}, \mathbb{P}=j, \boldsymbol{B}=j a$ ili $j$, a $\mathbb{D}=j u$ ili $j$. U riječima koje se navode kao primjeri u ovome radu i ta su slova transliterirana prema pravilima Staroslavenskoga instituta u Zagrebu: $\mathbf{u}=$ $\hat{c}, \Pi \mathbb{P}=\hat{\jmath}, \boldsymbol{B}=\hat{e}$ i $\mathbb{D}=\hat{u}$. 
položaju vrlo je rijetko ispušten: $d n i(20 \mathrm{v})$, najčešće je vokaliziran samoglasnikom $a$, i to bez obzira nalazi li se u jakome položaju: dan (18v), edan (20v) itd., ili u slabome položaju, gdje je riječ o jakoj čakavskoj vokalizaciji: množastvom (20v i drugdje), cesarastvo (19v), ces(a)rastvueš (21r), kadi (19v i drugdje), va (20r i drugdje), sa (21r i drugdje), vaze (20r i drugdje) itd.

Tekst iz CFat ima miješani ikavsko-ekavski odraz jata: svitu (20r), diva (20r), prid (20r), naprid (20v), lipotom (20v), slipoga (21r), zapovidi (21r), griha (19r), dvima divoikama (19v), svitlom (21v), divstvo (21v), divo divota (22r), dila (22r), kriposti (22r), č(lovê)k' (19r), ali: prestola (18v), mesta (20r i dr.), pesni (20v i dr.), verovati (21r), pobedivši (21r), bela (21v), besede (20v) itd. Zabilježeni su i neki dvojni oblici: telo (20v, 21r) / tilo (20v), diva (21v) / dev (21v), devami (21v), kao i primjer tzv. hiperikavizma: postilicom (20r), postilu (20v i dr.) Slovo \& bilježi se isključivo za glasovnu skupinu ja na početku, u sredini i na kraju riječi: ê (21r), priêla (18v), Mariê (18v) itd.

Slogotvorno $r$ uglavnom je bez popratnoga samoglasnika: držal $(18 \mathrm{v})$, svrhu (19v), prvo (19r), srcih (19r), trpi (20r), smrti (20r), beskvrni (22r) itd., a samo na jednome mjestu dobiva popratni samoglasnik: semrtiû (20r). Slogotvorno $l$ zamijenjeno je s u: puna $(19 \mathrm{v})$, duboko (20r). Zabilježeno je i sekundarno slogotvorno $r \mathrm{~s}$ ispuštanjem samoglasnika: prnesoh (20r), prnesiše (22r), Brnard (22r).

Rotacizam je posve proveden: ûre $(19 \mathrm{v})$, tere (18v i drugdje), nigdar (19r i drugdje), more (19r) itd. Očuvana je suglasnička skupina čbr: črevi (19r), a suglasnička skupina čbt zamijenjena je mlađom $\check{s} t: s ̌ t i(19 \mathrm{v})$ i dr., poštuûĉi $(18 \mathrm{v})$, poštena $(19 \mathrm{r})$, poštene (21r).

Zabilježeno je jednačenje po zvučnosti na mjestima gdje se sastaje prijed$\log \mathrm{s}$ imenicom ili pridjevom: $z$ dušom $(21 \mathrm{v})$, z nebeskoga otočastva $(18 \mathrm{v})$ itd., a na mjestu gdje se sastaje prijedlog sa zamjenicom dolazi i do jednačenja po mjestu tvorbe: $\check{s}$ nim (21r). Zabilježen je i primjer razjednačavanja nosnika na daljinu $(n, m>l, m)$ : zlamine $(21 \mathrm{v})$.

Prijedlog $v b$ kao samostalna riječ na jednome mjestu postaje $u$ (20r), ponekad se poluglas vokalizira: $v a$ (20r i drugdje), a najčešće se javlja u obliku $v(18 \mathrm{v}$ i drugdje). Poluglas u predmetku $v b z-\mathrm{u}$ izvedenicama na dvama se mjestima vokalizira: vazamši $(21 \mathrm{v})$, važgana (20r), a drugdje se piše bez znaka za poluglas vz-: vzlizeši $(18 \mathrm{v})$, vzdvih $(18 \mathrm{v})$, vzlublenago (19r), vskrse (19r), vzveličenu (19r), vzapi (19v), vzide (20r i drugdje), vskrsnul (20r), vzašal (20r), vzašastiû (20r), vzgrmi (20r), vstani (21r), vsta (21r), vzvišena (22r), vznesena $(22 \mathrm{v})$ itd. 
Samoglasnik o u korijenu riječi ponekad prelazi u e: grob (20v i drugdje)/ greb (20r). Riječ meč (22r) možda je posljedica ekavske vokalizacije poluglasa zbog dublete u stsl. mbčb / mečb. Praslavenska glasovna skupina * $t j$ odražava se kao ć: picu (22r), obeĉala (22r), hoĉ (19v) itd., a glasovna skupina *dj kao $j$, koje se bilježi slovom Il: mêu (20v), a nije označeno u samoglasničkoj skupini oe: roena (19r), gospoe (21r), osloboen (21r), ue: tuei (18v) i aê: pohaêla (20r). Prednji nosni samoglasnik e odražava se rjeđe kao e: poče (20r), nego uglavnom kao ja: priêti (19r), priê (19r), priêmši (20v). Praslavenska glasovna skupina *stj, odnosno *skj odražava se kao šć: kršĉen (20r), zašĉiti (20v), mešçane (20c), nišçe (19v, 21r), jošče (22r). ${ }^{29}$ Glasovne skupine jt i jd čuvaju se u izvedenicama od glagola iti: poiti $(19 \mathrm{v})$, naidete $(20 \mathrm{v})$.

Druga palatalizacija uglavnom je provedena: ruci (18v), ispovidnici (19r), ali ne kod imenica muškoga roda $o$-deklinacije u instrumentalu množine: $m u$ čeniki (19r). Provedena je sekundarna jotacija: smrĉu (22v), svetošĉu (19r i dr.), svetošćci (19r), svetošĉom (19v), osim ponekad u instrumentalu jednine: semrtiû (20r), milosrdiû (18v), radostiû (20r), gdje zbog jake vokalnosti ne može doći do jotacije. Glas $i$ ponekad ispada u prijedlogu $i z$ : $z$ nebeskoga otočastva (18v), z raê (20r), z molitve (22r). Početni se samoglasnik prejotira u sljedećim primjerima: jideniû (22r), Jepesi (20r), jošce (22r), ûtrni (19r), ali ne u: ednu (19v), ednoga (19v i drugdje), ednom (19v i drugdje), edan (20r i drugdje), esam (19v), ednim (21v). U drugom aktivnom participu preterita muškoga roda poluglas se ispred završnoga $-l$ vokalizira kao $a$ : mogal $(18 \mathrm{v})$, prišal $(18 \mathrm{v})$ itd. U jednom primjeru nema epentetskoga $l: z d r a v e \hat{e}(19 \mathrm{v})$, ali je zabilježeno epentetsko $d$ : izdravilskih (21r). U nekim je riječima zabilježena afereza, tj. ispadanje glasa na početku riječi: oceš $(19 \mathrm{v}, 20 \mathrm{r})$. Glas $g$ ispred glasa $k$ prelazi u $h$ u riječima zlahka $(19 \mathrm{v})$ i lahko $(19 \mathrm{v})$.

U prilagodbi stranih imena nema vitacizma: Elizabeta (21v), a grčki glas $p h$ prelazi u glas $p$ : Jepesi (20r), i u glas $f:$ Jezofatski (20v). Grčka suglasnička skupina $n g$ bilježi se kao nj: evanjelist (19r), evanjelski (21r). U grecizmu apustoli (20r i drugdje) grčko o zamijenjeno je s $u$ kao i u starijim hrvatskoglagoljskim tekstovima, no zabilježen je i jedan primjer s $o$ : apostolov (19r).

\footnotetext{
${ }^{29}$ Po glasovnoj vrijednosti slova w (c) CFat se razlikuje od većine hrvatskoglagoljskih pisanih spomenika jer se ono u njemu uvijek čita kao [ć], dočim se za glasovnu vrijednost [ک̌́ć] bilježe dva slovna znaka: யய̛̈. Usp. GALIĆ 2018: 106-107.
} 


\subsubsection{Morfologija}

Imenice se uglavnom sklanjaju prema mlađim paradigmama. Ostatci starijih oblika u morfologiji imenica muškoga roda nalaze se u genitivu jednine: dne (20r), vokativu jednine na $-u$ : $\operatorname{sinu}(20 \mathrm{v})$, lokativu jednine na $-i$ : životi (19v i drugdje), veki (21r), i na -e: grade (21r), nominativu množine na -e: mešĉane $(20 \mathrm{v})$, genitivu množine s nultim nastavkom: patriarah (19r), $\mathrm{kr}$ šçan (21r), dativu množine na -om: učenikom (20r), apustolom (20v), lokativu množine na -eh: dneh (20r), instrumentalu množine na -i: mučeniki (19r), apustoli (20v). U genitivu množine muškoga roda susreće se mlađi oblik -ov: apostolov (19r), anjelov (19v i drugdje), mučenikov (21r), sinov (21r), ispovidnikov (22r) itd., a ponekad i bez završnoga -v: apustulo (19r), mučeniko (19r), ispovidniko (19r), anjelo (20v).

Imenice ženskoga roda zadržavaju starije oblike u vokativu jednine na -e: $D i$ ve Marie (22r), pored maiko (21r), instrumentalu jednine na -ju: svetošĉu (19v), radostiû (21v i drugdje), genitivu množine s nultim nastavkom: stran $(18 \mathrm{v})$, ruk (21r), dev (21r), div (19v), dativu množine na -am: divam (22r), lokativu množine na -eh/-ah/-ih: tomnosteh (!) (19r), pesneh (22r), devah (22r), knigah (19r), pustinah (22r), špilah (22r), hižih (22r) itd., instrumentalu množine na -ami: devami (21v) i na -i: pesni (20v i drugdje) i akuzativu dvojine na -i: ruci (18v).

Kod imenica srednjega roda stariji su nastavci zabilježeni u lokativu jednine na $-i$ : nebi (21r), teli (19r), milosrdii (22r), prije nego što je došlo do izjednačavanja dativa i lokativa jednine: govorenu (20r), pod utjecajem $u$-osnova, u lokativu množine na -ih: srcih (19r), nebesih (21r), ramenih $(21 \mathrm{v})$, zahvalenih (22r), bdenih (22r) itd., i instrumentalu množine na -i: vrati (20v).

Zabilježeni su stari produženi oblici pridjeva u nominativu jednine srednjega roda i lokativu jednine ženskoga roda: nebeskoe (19v), Božiei (22r), što su dijelovi teoloških naziva nastalih iz biblijskoga jezika: cesarastvo nebeskoe, v mudrosti Božiei te su preneseni onako kako su glasili u staroslavenskoj predaji. Uz pridjevski mlađi nastavak -oga: vzlublenoga (20r) zabilježen je stari nastavak za genitiv jednine muškoga i srednjega roda -ago: vzlublenago (19r), s(ve)tago (21v), što je najčešći staroslavenizam u neliturgijskim rukopisima, a dolazi iz liturgijske upotrebe, što se vidi po tome da se atribut nalazi iza imenice. Također su stariji oblici lokativa jednine ženskoga roda na -i: tuei (18v), lokativa jednine muškoga roda na -i, G(ospod)ni (21r), -ovi: Salamuno$v i(19 \mathrm{v})$, lokativa množine ženskoga i srednjega roda na -ih: cesarskih (19r), apustolskih (19r), malih (22r) itd., instrumentala množine muškoga roda na $-i$ : svimi (19r) i instrumentala množine ženskoga roda na -imi: inimi (21v). 
Osobna zamjenica u nominativu prvog lica jednine samo se na jednom mjestu piše kao $\hat{e}(21 \mathrm{r})$, a drugdje kao ja $(18 \mathrm{v}, 19 \mathrm{v}, 20 \mathrm{v}, 22 \mathrm{r})$. U sklonidbi osobnih zamjenica u trećem licu u dativu jednine ženskoga roda javlja oblik bez protetskoga $n$-: ei (22r), a drugdje uvijek imaju protetsko $n$-. Potvrđen je instrumental jednine sa starijim nastavkom - $\hat{u}$ : mnôิ (21r). Odnosna zamjenica dolazi ponekad u starijem obliku kaê (19v i drugdje), a većinom u skraćenom obliku, koji je nastao kontrakcijom samoglasnika nakon ispadanja intervokalnog $j$ : $k i$ (18v i drugdje), $k a$ (18v i drugdje), $k u$ (19r i drugdje). Kod posvojnih zamjenica očuvan je stariji nestegnuti oblik u dativu jednine ženskoga roda: moei (21r). U genitivu jednine muškoga i srednjega roda povratno-posvojne zamjenice očuvan je stariji nastavak -ego: svoego (19r), pored mlađega -ega: svoega (20r i drugdje), a u instrumentalu jednine ženskoga roda nastavak - $\hat{u}$ : svô̂ $(19 \mathrm{v})$. Nestegnuti oblik u genitivu jednine svoega smjenjuje se sa stegnutim svoga (20r i drugdje), a u dativu jednine zabilježen je samo nestegnuti oblik svoemu (21r i drugdje). Uz čakavske zamjenice ča $(20 \mathrm{r}, 21 \mathrm{v}$ i drugdje) i zač (18v i drugdje), javljaju se i starije zamjenice, kao npr. pokazna zamjenica $s b$, si, se: sega (18v, 20r), se (18v), siê (20r i drugdje), i odnosna zamjenica êže (20r, 21v), i to samo u biblijskim citatima. U zamjeničkom pridjevu vbsb/vbse/vbsê provedena je metateza: sve (19v i drugdje), svimi $(19 \mathrm{v}$, 19r), a stariji oblik susreće se samo na jednome mjestu: vsim (19v).

Kod glagola u prezentu pored nastavka za prvo lice jednine -im/-em: primam (19r), učinim (21r), molim (22v), esam (18v, 19v), pojavljuje se i na-

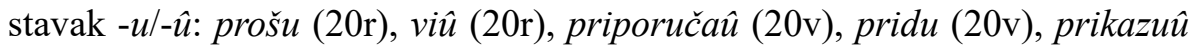
$(21 \mathrm{v})$, umru $(22 \mathrm{v})$. U drugom licu jednine mjestimično je očuvan nastavak - ̌si: prosiši (20r), budeši (21r), a u trećem licu jednine -et: pripodablaet se $(19 \mathrm{v})$, giblet se $(19 \mathrm{v})$, proidet $(22 \mathrm{v})$.

Česta je upotreba participa, i to većinom aktivnih participa prezenta u nominativu jednine i množine muškoga i ženskoga roda, gdje prevladava particip na -ĉi: govoreĉi (20v), hoteĉi (19r), videĉi (19r), pozdravlaûći (19v) itd., koji se više ne sklanja, nego se shvaća kao glagolski prilog. Očuvan je i prvi aktivni particip preterita: rekši (19r), vzdvigši $(19 \mathrm{v})$, slišavši $(18 \mathrm{v})$, priêmši $(20 \mathrm{v})$, vidivši $(20 \mathrm{r})$, prišadši $(21 \mathrm{r})$, pobedivši $(21 \mathrm{r})$, vazamši $(21 \mathrm{v})$ itd., koji također poprima službu glagolskoga priloga. Pasivni particip preterita vzlublenoga (20r) zabilježen je već i u CGrš (168r). 


\subsubsection{Leksik}

Dio leksika naslijeđen je iz staroslavenskoga jezika: otočastva $(18 \mathrm{v})$, priêti (19r), žitji (19r), viêhu (22r), piĉu ${ }^{30}$ (22r), mira (20r), raba (18v), glagolu $(18 \mathrm{v})$, pročaê $(22 \mathrm{v})$, umilenstvu $(22 \mathrm{r})$ itd. Arhaične su i glagolske imenice na -je: činene (19r), začetiû (19r), milosrdiê (19v), vzašastiû (20r i drugdje), želinem (20r), petiem $(20 \mathrm{v})$, êvlenih $(21 \mathrm{v})$, videniem $(21 \mathrm{v})$, pošastiem $(21 \mathrm{v})$, pohotenie (22r), jideniû (22r), zahvalenih (22r), bdenih (22r).

Zabilježeni su i primjeri kontaktne sinonimije: sega (20r) / toga (19r), mir (21r) / svita (20r), se (18v) / to (18v), žitji (19r) / život (20r), priêti (19r) / primi (20r), kralueš (21r) / cesarstvueš (21r) itd.

Od riječi stranoga podrijetla pojavljuju se grecizmi: psalmista (18v), anjel (20r), dêvlo (20r), patriarah (19r), apustoli (20r i drugdje), kivot (21r), horov (21r), evanjelski (21r), arhierei (21v), semitizam h(ero)vim (22r), latinizmi: eri $(20 \mathrm{v})$, regula $(22 \mathrm{r})$, oltar $(21 \mathrm{v})$, i talijanizmi koji pripadaju čakavskomu jeziku: kuntentâ̂ci se (22r), terče (22r), none (22r).

\subsubsection{Sintaksa}

Iz starijega predloška zadržane su zamjenice u genitivu jednine za izricanje posvojnosti: $v$ črevi nee (19r), pesni nih (20v), ruke nega (21r) itd., koje uglavnom dolaze poslije imenice, no ne uvijek, što je znak mlađega jezičnog stanja: v nega stan (18v), nee čudnu smrt (19r). Veoma se rijetko posvojnost izriče posvojnom zamjenicom: muke negove (19r), ruke negove (20v), negova ... maika (21r).

U sintaksi participa obilježja su starijega jezika ostatci sklonidbe participa. Zabilježen je jedan apsolutni dativ s prvim aktivnim participom preterita: učenikom pošadšim' (20r). Aktivni participi prezenta sklanjanju se samo u rijetkim slučajevima u atributnoj upotrebi u dativu množine muškoga roda: vsim iĉcicim $(19 \mathrm{v})$ i u predikatnoj upotrebi u konstrukciji akuzativa s participom: muža greduća $(21 \mathrm{v})$. Neobična je rečenična konstrukcija s participom: verovati budeĉi mnim da budeši zdrav, gdje se particip budeĉi upotrebljava

\footnotetext{
${ }^{30}$ Staroslavenska riječ piça nalazi se u dvama tekstovima iz FgTrans, u legendi o sv. Eustahiju (FgEust), što je jedan od najstarijih slavenskih hagiografskih tekstova prevedenih s grčkoga jezika, i u fragmentu neodređene homilije FgSerm (MIHALJEVIĆ; VINCE 2012: 165). Grabar navodi Ivšićevo mišljenje da je u legendi o sv. Eustahiju riječju piĉa prevedena grčka

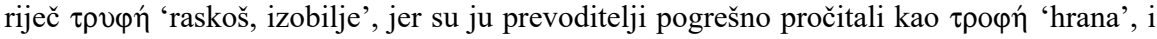

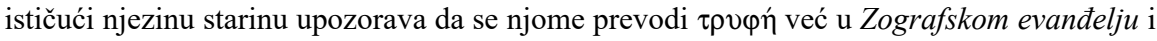
Sinajskom euhologiju. Vidi GRABAR 1981: 131.
} 
predikatno, a svršeni prezent glagola biti ima stari nastavak za drugo lice jednine $-\check{s} i$, kojim se izriče budućnost.

Latinski utjecaj primjetan je u upotrebi imenica u genitivu s prijedlogom od: posveceniê od anjelov (19r), puk od anjelov (20v), kao i u rečenici: zač evanjelist pišuĉ od nih reče (19r).

Navodi iz Biblije prenose se iz hrvatskostaroslavenskoga jezika: se raba G(ospodi)na budi meni po glagolu tvoem (18v) (usp. Lk 1,38); a to se skazue $v$ toi besedi kadi di kaê e(stb) siê êže vzide od pustine to e(stb) od sega mira to e(stb) semrtiû (20r); govoreĉi kaê e(stb) siê êže vzide po pustini raskoši obilun̂ci i pročaê (21v) (usp. Pj 8,5).

\subsection{Jezikoslovna analiza teksta iz CVar}

\subsubsection{Fonologija i grafija}

CVar zbornik je pisan latinicom s različitim grafijskim rješenjima za iste slavenske glasove, što se posebno odnosi na palatale. ${ }^{31}$

Poluglas u jakom položaju uglavnom je vokaliziran, a samo se u rijetkim slučajevima bilježi apostrof: d'ni (5), s', $k^{\prime}(6,7), s^{\prime} n i(8)$ itd. Isto tako apostrof se pojavljuje i na onim mjestima gdje izvorno nije postojao poluglas: t'koie (6), s'drauu (7), s'lauu (7) kako bi se razbila suglasnička skupina. ${ }^{32}$

Odraz jata je jekavsko-ikavski: biesce (3), dieua (3), tíelom (3), miesezzà (3), miefta, (4), piesan (5), pietti (5), liepos (5), griefieh (5), trieba (6), dieuizze (6), fuietla (6), viecnogha (6), suietlofti (6), sliedisce (6), priliepisce (6), namierio (8), prisciuiela (3), priminu (3), primínuti (3), prid (3), príslaunu (3), pricifta (3), prinesseni (4), bisce (4), oudi (4), fapouidio (7), dili (7). Rijetki ekavski oblici: pred (3), telesniem (3), potreba (6) mogu se promatrati kao staroslavenski elementi ili kao utjecaj starijega čakavskoga predloška.

Slogotvorno $r$ uvijek se piše s popratnim vokalom a: vskarsnuo (3), karstio (3), Iffukarftouu (3), ufdarsciatti (3), naiparuo (5), sartalla (4), usdarfcati (4), fuarhu (6) / suarhu (8), sarzze (5), parsieh (6), darscanije (6), martuu (6), fargbe (6), vuarcchi (6), uskarsni (7), Ifukarfta (7), vskarsnuo (7), s'martti (7), tuardo (7), uarhu (8). Slogotvorno $l$ ostvaruje se kao u: putti $(4)$, puk $(5,6)$, susa / fusà $(3,4)$, napunise (6).

\footnotetext{
${ }^{31}$ Usp. MALIĆ 1997: 456-459.

${ }^{32}$ Mjesta iz zbornika CVar navode se i označavaju prema stranici na kojoj se nalaze u izdanju KARÁSEK 1913: 1-15.
} 
Kod prilagodbe imena stranoga podrijetla nema vitacizma: Jakob (3), $B a$ biloniu (4), a grčko slovo $\varphi$ bilježi se slovom f: Epifan (3), Josafatouu (7). Ostala imena prenose se na sljedeći način: Tomas (7), Ifukarft (7), Iuan (7), Jesufs / Iefuss (3) / Jesus (5), Jerusalem (4), Pauao (6).

U tekstu su vidljive sljedeće štokavske jezične osobine. Nema jake vokalnosti: mnosctuo / mnoŝtuu / mnofctuo (5), mnosctuom (7), promjena $l \mathrm{u} o$ : Anghieo (3), paomu (4), Pauao (6); javlja se hiperjekavizam: pastiea (!) (6), redovito u nastavku za instrumental jednine pridjeva: telesniem (3), doftoiniem (4), velikiem (6), instrumental množine pridjeva: Ifraelskiem (5) i lokativ množine imenica i pridjeva: griefieh (5), fuetieh (5), ostalieh (6), oblazieh (7); pisanje slova $j$ na mjestu nekadašnjega jata: suijechie (5); pojava zamjenica fcto / scto (4) / scto (6), fascto (4) / safcto (7), sctosse (4), nitko (5) i nifĉta (7); odraz praslavenske glasovne skupine *stj, odnosno *skj kao št: godiscta / godisĉta (3), jofĉte (4) / iofĉte (7), pofcteno (4), poĉtenie (5), pofĉteniem (6); odraz praslavenske glasovne skupine *dj kao $d$ : Anghieo, naghiesse, neuighiu (3), meghiú, gofpoghie, vighmo (4), prighi (5), gradiani (6), mlaghi (6), Arkangela (7), uporoghiniu (7), fargbe (6); riječ iesik (6) bez čakavskoga odraza e u $a$ i bez metateze suglasnika u zajik; odsutnost nove jotacije: fuietlosti (3), bratia (3), tretie (3), listie, priminutia (4) vskarfnutie (5), isrieti (6); ispadanje suglasnika i samoglasnika: pofcio (3), fapouiesc (3), tò ies (3), fces (3), milòs (3), vulas (3), blagofouu (3), s'fpouiednizim (5), gnieouieh (6), cíàs (7), Vanghielista (4), bíescat (8); riječi koje uza se imaju česticu za isticanje: tutako (3 i drugdje), otto (4), tadar, t'kogodier, kakono (7).

\subsubsection{Morfologija, sintaksa i leksik}

U morfologiji gotovo da više nema starijih oblika. Kod imenica su jedino zabilježeni: lokativ množine muškoga roda na -eh: griefieh (5), fuetieh (5), dativ množine na -om: Apostolom (5), ouzam (6). Kod zamjenica dativ množine i instrumental množine osobne zamjenice za drugo lice množine na -i: vami $(7,6)$, genitiv jednine muškoga roda pokazne zamjenice: segai $(3,4)$ u izrazu segai suieta, ${ }^{33}$ uz mlađi oblik zamjenice u izrazu s'ouoga Suieta (3). I dalje se treće lice jednine osobne zamjenica u genitivu upotrebljava za izricanje posvojnosti: tielo gnie, na grob suetignie (6). Kod glagola javlja se nastavak $-u$ za prvo lice jednine prezenta: neuighiu (3), príporucíuiu (4). Futur prvi tvori se pomoćnim glagolom imati: imafc prímínutí (3). Brojne su glagolske

${ }_{33}^{33}$ Taj izraz MALIĆ 1992: 113 naziva »okamenjeni izraz konfesionalnoknjiškoga podrijetla«. 
imenice tvorene dometkom -iel-je: vsuifcenie (3), trenutie (4), priminutia (4), vskarfnutie (5), darscanije (6), rastuorenie (7).

U sintaksi je utjecaj staroslavenskoga jezika najneznatniji. Uočljiva je upotreba participa, što je ostatak latinskoga predloška, ali se oni više ne sklanjaju i poprimaju ulogu glagolskih priloga: s'miscglíaiuchi (3), scdecchi (4), gouorecchi (4 i drugdje), rekfci (4) / réksci (6), vidiéusci (5), fiede(c)hi (5), uprasciaiuchi (6), tufcechise (6), ciudecchise (7), scialecchisse (7) itd. Primjetan je utjecaj talijanske sintakse, što je posljedica prijevoda s talijanskoga jezika, kao primjerice u sintaktičkom talijanizmu $z a+$ infinitiv: za ukasati mu (8).

Česti su talijanizmi, tj. venecijanizmi: appocrifo (3), legamo (3), mefctra (4), kandiele (5), lukierne (5), aerra (7), templo (7), predikatti (3 i drugdje), tunika (8), linzuo (8), bandieru (8) itd.

\subsection{Usporedna tekstološka analiza tekstova iz CFat i CVar}

Pored toga što su oba teksta palmine predaje sadržajno međusobno vrlo slična, u njima nailazimo i na neke sadržajne razlike uvjetovane time što je tekst iz CVar nastao u prijevodu s talijanskoga prijevoda latinskoga izvornika. Tako se za pripovijest o Mariji u CFat kaže da joj je podrijetlo svetopisamsko: kako e ona bila umrla s(ve)to pismo nam skazuje prilika šti se (20r), dočim se u CVar tvrdi da je pripovijest apokrifna: Legamo u pifmu koiiesse foue appocrifo, tò ies recchi neifkusceno pifmo: koie recce da Iuan vanghielista píssa, $i$ naucij (3). Oba teksta imaju navedena ista mjesta Marijine molitve i uzašašća: gora Sionska i Jozafatska dolina. Također se cijela radnja odvija u Jeruzalemu. Oba spominju vrijeme kada se to dogodilo: po Vzašastiju sina svoega ... 4 leta e živila potom (CFat 20r), dočim CVar donosi pregled Marijinih godina po svim važnim događajima njezina života, zaključujući da je imala 71 godinu i šest mjeseci kada je umrla i bila uznesena na nebo. Uz Marijinu želju da k njoj dođe Ivan i svi drugi apostoli i da Isus uzme njezinu dušu, dvije Marijine želje iz CVar ne navode se u CFat: da ne vidi vlast Sotone i da sazna ime anđela. Anđeo joj ne kazuje svoje ime ... cudno i veliko (4), ali joj obećava ispunjenje svih drugih želja i ostavlja palmu, koja će se nositi na sprovodu pred njezinim odrom. Oba apokrifa palmine predaje sadrže Marijin spomen Isusovih riječi pod križem da je Ivan njezin sin, a ona njegova majka, čega nema u betlehemskoj predaji, u kojoj velik dio teksta čine odgovori apostola otkuda su došli i što su činili kada ih je oblak na čudesan način prenio k Mariji. U palminoj predaji to se iskazuje samo u jednoj rečenici u obama sačuvanim hrvatskim tekstovima. Najveća razlika između CVar i CFat sastoji se u tome da CVar 
opsežnije prenosi razgovore između Marije i Ivana, Marije i Isusa, te Isusa i anđela, dočim su u CFat ti razgovori samo sažeto prepričani. ${ }^{34}$ Obraćeni Židov Jefonija je na kraju apokrifa u betlehemskoj predaji imenovan, isto kao i anđeo Gabrijel, dočim se u palminoj predaji naziva samo po svojem položaju, i to knez u CFat i starješina popovski u CVar. U CVar on čak poslije obraćenja nosi rajsku palmu, što se ne spominje u CFat. Oba teksta palmine predaje povezuje rečenica koju izgovaraju anđeli kada je Marija uznesena na nebo, a koja je navod iz Pjesme nad pjesmama, a ne nalazi se u tekstovima betlehemske predaje. Tekst u CVar razlikuje se od teksta CFat također i po tome što se u njemu Isus obraća Mariji riječima iz Marijinih litanija: pokrouu slauè, sud sciuotnij, templo nebesko (7).

\section{ZAKLJUČAK}

Apokrif Usnuće Bogorodice očuvan je u hrvatskoj srednjovjekovnoj književnosti kroz četiri stoljeća u tekstovima koji pripadaju dvjema tekstovnim predajama - betlehemskoj predaji, koja se očuvala na kršćanskom Istoku, i palminoj predaji, koja se proširila na kršćanski Zapad, od fragmentarnog teksta iz Pazinskih fragmenata, koji potječu iz 14. stoljeća, preko nešto mlađega cjelovito sačuvanog teksta iz Vinodolskoga zbornika iz 15. stoljeća i još mlađega teksta iz 16. stoljeća koji se nalazi u Grškovićevu zborniku, sve do najmlađih tekstova iz Fatevićeva zbornika i Codex Varia Variorum 39 iz 17. stoljeća, u kojima je apokrif uklopljen u propovijed za blagdan Velike Gospe. Stoga se na primjeru toga apokrifa jasno može dokazati kako je hrvatska književnost u svojim početcima i u prvome razdoblju bila otvorena za utjecaje koji su dolazili s Istoka, tj. za tekstove prevedene s grčkoga na staroslavenski jezik, a u kasnijim se razdobljima otvorila utjecaju književnosti latinskoga Zapada i naposljetku njezinim talijanskim prijevodima. Iz istoga se razloga mogu dobro pratiti i povijesne mijene jezika, koji je kroz stoljeća postupno postajao sve sličniji govornomu narodnomu jeziku, a sve je više gubio svoj-

\footnotetext{
${ }^{34}$ Primjerice u CVar nalazi se Marijin odgovor Isusu koji možemo povezati s mjestom iz FgTrans, koje se ne nalazi ni u CVinod ni u CGrš, a svjedoči o tome da je i latinski predložak slavenskih prijevoda bio prijevod grčkoga izvornika palmine predaje koji je s grčkim tekstovima betlehemske predaje imao neka zajednička mjesta: Blascenume ghouorè sui naroddi ere ftuorij mene velikij (CVar 5) : i stvoril'mi esi velikoti silni . i blažet'me vsi rodi (FgTrans $2 \mathrm{~d})$.
} 
stva naslijeđena iz hrvatske redakcije staroslavenskoga jezika, kako u gramatici tako i u leksiku.

Za razliku od teksta apokrifa Usnuće Bogorodice iz FgTrans, koji sadrži krajnje doslovan prijevod grčkoga izvornika, koji je povezan s prvobitnim slavenskim prijevodom $\mathrm{s}$ grčkoga, te ima srodne tekstove u brojnim rukopisima u drugim redakcijama staroslavenskoga jezika, tekst iz CVinod sadrži samo znatnu preradu prvobitnoga prijevoda. Zabilježene su samo mjestimične podudarnosti koje se svode na pojedine riječi i izraze, te vrlo rijetko i na pojedine rečenične konstrukcije. Razlike između tih dvaju tekstova u odnosu na grčki izvornik toliko su velike da se može zaključiti kako tekst iz CVinod ne samo da nije preveden s grčkoga nego nije ni neposredna prerada teksta iz FgTrans. Tekst iz CVinod samo je u dalekom srodstvu tekstom iz FgTrans, a oblikovan je na osnovi drugih nesačuvanih prijepisa koji su u stoljetnoj slavenskoj predaji apokrifa stajali između staroslavenske matice i njega. Shodno tomu, nema ni grčkoga predloška koji bi stajao u temelju teksta iz Vinodolskoga zbornika, niti je moguća sustavna usporedba s grčkim izvornikom.

Prerada provedena u tekstovima iz CVinod i CGrš obuhvaća razne postupke, od skraćivanja, odnosno ispuštanja i sažimanja, preko preoblikovanja i pojednostavljenja do dodavanja i tumačenja. Vrlo su rijetka mjesta na kojima se zbornički tekstovi doslovno drže grčkoga izvornika, nešto više je onih mjesta koja sadrže nedoslovan prijevod s grčkoga, a najvećim su dijelom ti tekstovi prepričavanje sadržaja prijevoda apokrifa drugim riječima. Preinake u preradi ponekad su i posljedica nerazumijevanja predloška i nastojanja da se tekst učini razumljivijim.

Tekst CVinod najstariji je među sačuvanim hrvatskoglagoljskim zborničkim tekstovima apokrifa. Iako je njegov jezik obilježen prodorom govornoga narodnoga jezika, pomlađivanje nije uvijek dosljedno provedeno tako da je u tekstu ostao cijeli niz riječi, oblika riječi i sintaktičkih sklopova iz starijega predloška. Jezik CVinod uzoran je primjer hrvatsko-staroslavenskoga jezika, koji se razlikuje od starijega hrvatskostaroslavenskoga jezika u FgTrans po većem udjelu govornoga jezika i većem stupnju pomiješanosti elemenata staroslavenskoga i starohrvatskoga jezika. Ostatci starijega staroslavenskoga predloška nalaze se sačuvani ponajprije u morfologiji, gdje se miješaju staroslavenski i starohrvatski oblici, najviše u konjugaciji prezenta glagola i u deklinaciji imenica, posvojnih i pokaznih zamjenica.

Tekst apokrifa iz CGrš jezično je mlađi, sadržajno kraći, doživio je veće preinake i izmjene - kraćenja, sažimanja i dodavanja - nego tekst iz CVinod u odnosu na tekst iz FgTrans. Ta dva zbornička teksta nisu neposredno po- 
vezana $\mathrm{u}$ tom smislu da bi tekst iz CGrš bio prepisan iz starijega CVinod, ali zajednička mjesta u tim dvama tekstovima, osobito ona kojih nema u drugim poznatim tekstovima, kao i pisarske pogreške na istome mjestu u obama zbornicima pokazuju da su ta dva teksta međusobno veoma srodna te da se mogu svesti na isti pretpostavljeni slavenski predložak. U odnosu na FgTrans jasno je da su se tijekom stoljeća prepisivanja i prerađivanja nejasna mjesta u prijevodu još više iskvarila sve do neprepoznatljivosti smisla ili su se jednostavno određeni dijelovi teksta ispustili.

Tekst apokrifa u CVar kao i tekst iz CFat uklopljen je u jednu dulju propovijed o Mariji kao o nebeskoj kraljici. Tekst iz CFat znatno je kraći i samo ukratko prepričava sadržaj apokrifa, a nije prijepis ili prerada nekoga starijeg teksta. Tekst iz CVar znatno je opsežniji, s više opisa, s čestim i dužim razgovorima među likovima i bogatim prikazom radnje. Po tome i po nekim izrazima koji su veoma slični onima iz FgTrans tekst u CVar bliži je starijim hrvatskoglagoljskim tekstovima apokrifa o usnuću Bogorodice nego tekst u CFat.

Iako u sebi sadrži neke elemente hrvatskostaroslavenskoga, jezik kojim je pisan tekst iz CFat mlađi je hrvatsko-staroslavenski jezik, u kojem je udio narodnoga čakavskoga jezika još veći nego u tekstovima iz CVinod i CGrš, što je vidljivo na svim jezičnim razinama. Tako se u CFat nalaze jezične promjene koje su i danas svojstvene ravskomu čakavskomu ikavskomu govoru, a sve je manje primjera starijega jezičnog stanja - stariji nastavci u deklinaciji imenica, pridjeva i zamjenica i u prezentskoj konjugaciji, zatim grecizmi i napokon arhaizmi, koji se mogu promatrati kao starije stanje samoga čakavskoga jezika ili kao okamenjeni ostatci starijega razdoblja hrvatskostaroslavenskoga jezika, pogotovu kada su biblijsko-liturgijskog značenja i kao takvi imaju svoju namjenu unutar propovjednoga stila.

Tekst iz CVar sadrži prijevod talijanske prijevodne prerade latinskog Pseudo-Melitonova teksta Transitus B. Pisan je nesustavnom latiničnom grafijom na narodnom hrvatskom jeziku, točnije na zapadnoštokavskom dubrovačkom poddijalektu, koji je dio novoštokavskoga jekavskoga dijalekta štokavskoga narječja hrvatskoga jezika, a svojstvena mu je velika prisutnost čakavizama, mjestimice ikavizama i brojnih talijanizama, odnosno venecijanizama, i posve neznatan udio staroslavenskih elemenata. Da je tekst iz CVar mlađi od onoga iz CFat, a time i najmlađi sačuvani tekst apokrifa o usnuću Bogorodice u hrvatskoj srednjovjekovnoj književnosti, jasno je već i po tome što je zapisan latinicom u 17. stoljeću.

Izuzme li se tekst iz FgTrans, koji je pisan na hrvatskostaroslavenskome jeziku i potpuno je doslovan prijevod grčkoga teksta na svim jezičnim razina- 
ma, najviše sačuvanih elemenata starijega jezičnog stanja nalazi se u prvom sljedećem zborniku - CVinod, a nadalje se može pratiti postupno pomlađivanje jezika iz zbornika u zbornik kroz stoljeća u kojima su nastajali. Dok se u CVinod nalaze još tragovi starijega jezičnog stanja, najviše na morfološkoj, zatim na leksičkoj i fonološkoj, a najmanje na sintaktičkoj razini, staroslavenski elementi u CGrš prisutni su u znatno manjoj mjeri. U hrvatsko-staroslavenskom jeziku teksta iz CFat još više preteže hrvatska sastavnica, da bi u narodnom štokavskom jeziku teksta iz CVar staroslavenski elementi ostali samo u svojem okamenjenom obliku preneseni iz crkvenoslavenske liturgijske književnosti.

\section{PRILOG}

Prilog sadrži prijeslove dvaju hrvatskoglagoljskih tekstova apokrifa Usnuće Bogorodice koji se nalaze u CVinod, pisanom ustavnom glagoljicom u prvoj polovici 15. stoljeća (Cod. III. a. 15, ff. $48 \mathrm{r}^{\mathrm{a}}-49 \mathrm{v}^{\mathrm{b}}$, Arhiv HAZU, Zagreb), i Grškovićevu zborniku, pisanom kurzivnom glagoljicom u drugoj polovici 16. stoljeća (Cod. VII. 32, ff. 167v-171r, Arhiv HAZU, Zagreb). Oba su teksta preslovljena na latinicu prema pravilima za preslovljavanje Staroslavenskoga instituta u Zagrebu, štapić $(\mathrm{I})=_{\mathrm{b}}$; apostrof $\left({ }^{\mathrm{r}}\right)=$ '; jat $(B)=\hat{\mathrm{e}}$; šta $(\mathrm{U})=\hat{\mathrm{c}}$; ju

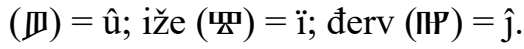

Kraćenja riječi u rukopisu označena titlom razriješena su u oblim zagradama ( ), ispuštena slova bez title dodana su u šiljatim zagradama \langle\rangle , dok se konjekture oštećenih i teško čitljivih mjesta nalaze u uglatim zagradama [ ]. Title, nadredni znaci i ligature nisu posebno označeni, a natpisana slova pišu se u istom redu kao i riječ kojoj pripadaju. Interpunkcija i pisanje velikog slova preneseni su vjerno izvorniku, što znači da se veliko slovo piše samo tamo gdje je ono i u glagoljičnom tekstu, imena se pišu malim slovom, a točka, koja se nalazi u sredini retka, bilježi se samo tamo gdje je pisana i u glagoljičnom tekstu. Precrtane riječi u retku CGrš $168 \mathrm{v}$ precrtane su i u rukopisu. Rukopisne pogreške označene su uskličnikom u zagradama (!). Tekst je u prijeslovu raščlanjen na stupce i retke jednako kao i u rukopisu te nema spojnice kojom se označava prijenos riječi u drugi redak. Radi lakšeg čitanja riječi su odvojene bjelinama. 


\section{Vinodolski zbornik, prva polovica 15. stoljeća,}

\section{Cod. III. a. 15, ff. 48r $\mathrm{r}^{\mathrm{a}}-49 \mathrm{v}^{\mathrm{b}}$, HAZU Zagreb}

\section{$48 r^{a}$}

Kada g(o)sp[odin' naš' umre bogorodica]

hoêše na s(ve)ti grob' s(i)na svo

ego g(ospo)d(i)na n(a)š(e)go is(u)h(rbst)a poklan

aûci kolênê [s]voi Pres(ve)tê

Molaše s'[v]oga s(i)na g(ospo)d(i)na

b(og)a da bi û vzel' i prestav

ilı ot sega s(vê)ta na v(ê)čni s(vê)tb

ot' sega v c(êsa)rstvo $n(e) b(e) s k o$ a i'û

dêi bêhu učinili di nigdore

hode n's(ve)ti grobs plakats se

ne s'mi da na grob' s(i)na m(a)riina

Da biše pr'vi d(ь)nь po vskr'sen'i g(ospod)ni

listo pride $\mathrm{s}(\mathrm{ve})$ ta $\mathrm{m}(\mathrm{a})$ riê na $\mathrm{s}(\mathrm{ve})$

ti grobs $s(i) n a t(e) r$ poče tvorit

i m(o)l(it)vu poziraûci v n(e)b(e)sa k s

vomu s(i)nu i n(e)b(e)sa se otvoriše ·

k' gospoi s(ve)toi m(a)rii Anĵ(e)l' ga

briels priletê $\mathrm{s} n(\mathrm{e}) \mathrm{b}(\mathrm{e}) \mathrm{sb}$ k' nei

ter ei $\mathrm{r}(\mathrm{e})$ če radui se $\mathrm{m}(\mathrm{a})$ rie usliša

na e(stb) m(o)l(it')vb tvoê v n(e)b(e)s(ê)hь hoĉe te

s(i)nь tvoi vzeti n(a) n(e)b(e)sa vb c(êsa)rs

tvo n(e)b(e)sko slišav'ši s(ve)ta

$\mathrm{m}(\mathrm{a})$ riê te rêči od an'̧̄(e)l (!) i vrati s

e v'spet' va vitleomb grad'

poêm'ši $\cdot \tilde{\mathrm{v}} \cdot(=3)$ divoike svoe ke noi

služahu r(e)če ims pr'nesête mi

kadil'nicu i dr'žeĉi kadilni

cu r(e)če g(ospod)i is(us)e h(rbst)e s(i)nu moi usl

iši glass moi i pošlli mi iv(a)na

ap(usto)la i da videĉi nega budu

se veseliti i ki su se $k$ te

bi prestavili s(ve)ti ap(usto)li i k

i su živi na semb sv(ê)tê vsi

ap(usto)li poš'li za v'sêh' stra 
n' a nadêû se s(i)nu moi da me

$48 r^{b}$

[hoĉeš uslišati i molitve $\mathrm{m}$ ]

oee Pride iv(a)nь d(u)h(o)mb s[(ve)timb]

s patomos'koga otoka epes

a i r(e)če ei radui se s(ve)ta m(a)rie

hoĉeš' poiti ot sega s(vê)ta

k s'vomu s(i)nu s(ve)ta m(a)riê

proslavi $b($ og)a govoreĉi g(ospo)d(i)

ne is(us)e h(rbst)e s(i)nu moi stv

ori čudesa da te se

uboû i ustraše ki su te pro

peli na križi i ki va te ne

vêruû i kada me v'zmešs

ot' sega s(vê)ta tada pridi

množastvo an'’̂(e)l' tvoihь

tere me vaz'mi s(i)nu moi $\mathrm{k}$ se

bi b(ož)e moi zač' su se iûdêi

obeĉali važ'gati têlo

moe i sa ovim' od'rom' na kom'

ležu kada um'ru I r(e)če s(ve)ti

iv(a)nь ap(usto)lb ne boi se gospoe

s(ve)ta m(a)rie iûdêi gl(a)se sli

še s n(e)b(e)sb da pri[hoû] br(a)tiê

moê i ap(usto)li d'n(b)sb simo d(u)hь

$\mathrm{s}(\mathrm{ve})$ ti $\mathrm{r}(\mathrm{e})$ če imb poidite va $\mathrm{v}[\mathrm{i}]$

tlêomb grad' k m(a)rii m(a)t(e)ri g(ospo)dni

i na oblacêh' vsed'še pri

doše vsi ap(usto)li t(e)rb ims r(e)če

s(ve)ti p(a)v(a)l' br(a)tê moê draga

povêite $\mathrm{m}(\mathrm{a})$ rii gospoei ot $\mathrm{ki}$

h' stranb e(stb) gdo v(a)sь prišal'

simo a m(a)riê vzvede se pro

ti ap(usto)l(o)mь v's(ê)mь t(e)rb imb r(e)če .

n(i)ne vêruû da oĉe priti s(i)nь

moi s n(e)b(e)sь a vaš' učitel'

i r(e)če iv(a)nь ê hoêhb k s(ve)tomu 


\section{$48 v^{a}$}

[mêstu v' gradê e]

pesê ter mi r(e)če d(u)hь s(ve)ti · poi v'

vit'lêomb na pozdrav'lenie ·

gospoino m(a)t(e)re g(ospod)a n(a)š(e)go is(u)h(rbst)a $\cdot \hat{e}$

$\mathrm{p}(\mathrm{e}) \mathrm{t}(\mathrm{a}) \mathrm{rb}$ v rimê bihi ûtr'ne poslušae

i d(u)h' s(ve)ti r(e)č(e) mi · idi v' vit'lê

omb na pozdravlenie

k' m(a)t(e)ri n(a)š(e)go is(u)h(rbst)a •

hoĉe se prestaviti

od' sega sv(ê)ta n(a) nь s(vê)tb .

An'd(r)êi i filip' ap(usto)lı i lu

ka i simun' i kananêi ti $\mathrm{v}$

staše iz mr'tvih' ti prido

še na pozdravl(e)nie $\mathrm{s}(\mathrm{ve})$ toi $\mathrm{m}(\mathrm{a}) \mathrm{r}$

ii va vitleom' - A p(a)v(a)lь ap(usto)lb .

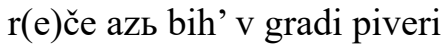

i d(u)hь s(ve)ti vshiti me simo •

toma $\mathrm{r}(\mathrm{e})$ če bih' $\mathrm{v}$ in'dii u al'v

ana kup'ca v polači i d(u)hb

s(ve)ti vze me i postavi me .

pos[redê] v(a)sb simo A ma

r'ko r(e)če ê bih' v leksan'dr'

skom' gradu pokaên'e čina

h' i d(u)h' s(ve)ti vshiti me simo •

êk(o)v'r(e)če ê bih' v er(u)s(oli)mê i d(u)hь

s(ve)ti vshiti me i pos

tavi me simo A bar'to

lomêi r(e)če ê bih' propov

êdae sl(o)vo b(o)žie i d(u)hь

s(ve)ti r(e)če mi idi va vi

tleoms i pridohь simo ·

i pridoše vsi ap(usto)li va

vitleomb k s(ve)toi m(a)rii m(a)t(e)ri

$48 v^{b}$

b(o)žiei a gospa s(ve)ta

m(a)riê vzd'viže rucê s 
voi k' b(og)u n(a) n(e)bo i pride $m n$

ožstvo anĵ(e)l' serapi

mi i serovimi (!) k nei kad

a ležaše m(a)ti g(ospod)na sl'

n'ce i mis(e)cь stahota

va vitleomê i množa

stvo s(ve)tih' prestoêhu

gospoi $\mathrm{s}(\mathrm{ve})$ toi i pride $\mathrm{m}$

nož(a)stvo lûdi neduž

nih' mnogo k' s(ve)toi m(a)rii va

piêhu velikim' gl(a)so

m's(ve)ta m(a)rie b(ogo)r(odi)ce p(o)m(i)l

u $\langle i\rangle n(a) s b$ k(a)ko ost(a)vl(a)šs n(a)sb gr

edoĉi n(a) n(e)bo a s(ve)ta gosp

oê bi m(i)l(o)st(i)va na grêšn

iki i na nevol'ne tu sl

êpi prozirahu tu kna

sti i hromi zdravi bi

vahu zn(a)m(e)niê se činahu

od' s(ve)te gospoe tu sta

hu radosti pêsni i ve

sel'e mnogo d(u)h(o)vno okolb

s(ve)te gospoe i vidêv'še ·

židove da se čini sl(a)v

a b(o)žiê ot ap(usto)l' ok(o)l' gospe s(ve)te

$b($ ogo)r(odi)ce i sveĉa emunь i iru

d' kralı i druzi židov

e veĉe straš'no i poslaš

e tisuĉ'niki n(a) m(a)riû b(ogo)r(odi)c

u i na ap(usto)li va vitleom'

$\mathrm{g}$ (ospod)a $\mathrm{v}$ domь $\mathrm{g}($ ospod)a $\mathrm{n}(\mathrm{a}) \check{\mathrm{s}}(\mathrm{e}) \mathrm{go}$ is(u)h(rbst)a

\section{$49 r^{a}$}

da êmu b(ogo)r(odi)cu i vse ap(usto)li

i nabraše dr'v' hoteĉi û s'

žgati i odar' nee i ap(usto)le v

se i kada pridoše k' hramu

k' d'varem' listo pride og 
an' znutar's hrama silu

b(o)žiû i požga e og'nem' an'

j(e)l' b(o)ži židove ki bihu

prišli k b(ogo)r(odi)ci i bi strahb ve

lik' po vs(e)m' gr(a)du i vsi lûd

i ki se $b($ og)a boêhu počaše $b($ oga $)$

vêrovati židove $\mathrm{t}(\mathrm{a}) \mathrm{ko}$ pra

vi sl(o)vo b(o)žie ako hoĉeš's

$\mathrm{p}(\mathrm{a}) \mathrm{s}(\mathrm{e}) n \mathrm{n}$ biti č(lovê)če vêrui v b(og)a

vs(ê)mb src(e)mb i v s(ve)tu b(ogo)r(odi)cu i

v s(ve)ti d(b)nь nedil'ni zač' e v' n(e)

d(ê)lû e priêla pozdravlenie

ot anĵ(e)la gabriela v n(e)d(ê)lû e

roen' $g$ (ospodi)nь $\mathrm{n}(\mathrm{a})$ šs $^{\prime}$ is(u)h(rbst)b vani vitle

oma grada va vrt(a)pe v n(e)d(ê)lû

vs(k)r'se iz mr'tvihь v n(e)d(ê)lû

hoĉe priti na sud' g(ospod)b n(a)šs .

I r(e)če g(ospod)b k materi svoei ne

skr'bi ko (!) se veseli i ra

dui naš'la si bl(a)g(o)dêt'

i sl(a)vu moû ku ê imam' s' o

c(e)m' moim' ke sl(a)ve nig'dore

ne more isp(o)v(ê)dati i d(u)ša

s(ve)taê tvoê hoĉe poiti

v s(vê)tlaê skrovicica k'di e

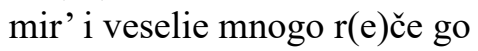

spa b(ogo)r(odi)ca s(i)nu moi predr

agi položi na mni ruku ·

$49 r^{b}$

desnuû tvoû i bl(agoslo)vi me s(i)nu

moi a gospa s(ve)ta b(ogo)r(odi)ca m(a)r

iê držeĉi č(a)s'tnuû desn

icu s(i)na svoego b(og)a tre r(e)če

s(i)nu moi prêdragi klana

û se desnici tvoee (!) pres(ve)t

ê tre û celova i r(e)če is $(u) h(r b s t) e$

s(i)nu moi primi d(u)šu moû · 
i budi m(i)l(o)st(i)v' vs(a)k(o)mu č(lovê)ku

ki priziva ime $s(v e)$ toe moe da $b$

udu pros'lavlena zač' sam'

te rodila s(i)nu moi A g(ospodi)nь b(og)b ·

r(e)če ei gospoe b(ogo)r(odi)ce vesel' se

da raduet' se sr'ce tvoe

v t(e)bi vs(a)ka d(u)ša ka priziva

ime čisto ne more poginuti

v v(ê)ki obrativ' se b(og)ь k s(ve)t(o)mu [petru]

$\mathrm{r}(\mathrm{e})$ če emu približi se vr(ê)me ho

ce poiti s(ve)ta b(ogo)r(odi)ca od' sega

s(vê)ta n(a) n(e)bo d(u)homb s(ve)timb z(a)to

počni pês(nь) pêti a s(ve)ti p(e)t(a)rb

poča naiprvu pês(nь) a(lelu)ê a vse

sili počaše velikim' gl(a)

s(o)mb a(lelu)ê A tada se lice

m(a)t(e)re g(ospod)ne prosvêti $\cdot \tilde{z} \cdot(=7)$ krat'

veĉe nego sln'ce sego s(vê)ta

i prostri se i vzdviže rucê

svoi gospoê b(ogo)r(odi)ca i ap(usto)le

bl(agoslo)vi svoû ruku i v'zdahnu

preda d(u)šu svoû prečist

uû b(ogo)r(odi)ca [s(ve)ta]ê v b(o)ži ruci a

$b(\mathrm{o}) g_{\mathrm{b}}$ prostri ruci svoi prês(ve)

ti priê b(la)ž(e)nu i neporočnu

$49 v^{a}$

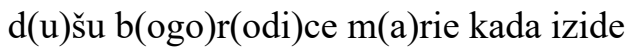

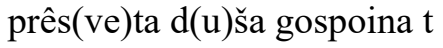

ada se v(a)sь grad' er(u)s(oli)mb na

pl'ni bl(a)ge vone a sili

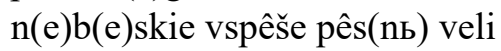

m’ gl(a)som' bl(agoslove)na ti esi v ž(e)na

h' a g(ospo)d(i)nь vze d(u)šu gospoinu

s(ve)timb d(u)homb n(a) n(e)bo a s(ve)ti ap(usto)

li vzeše s(ve)to têlo

ee i č(a)stno položiše na od

ar' i ponesoše vsed'še na 
· $\tilde{b} \tilde{i} \cdot(=12)$ obl(a)ka svitla i pol

ožiše v rai i k(a)da nesihu

s(ve)ti ap(usto)li t(ê)lo s(ve)te d(ê)vi m(a)r

ie tada ·ã $\cdot(=1)$ židovin' im

e[nemb] ofiniê tare poče raz'mi

tati odar' gospoin' na

t $\langle 0\rangle$ mь časi pride anĵ(e)l' b(o)ži

$\mathrm{i}[\mathrm{u}]$ siče mu ruci v pleĉu i $\mathrm{p}$

oča m(o)l(i)ti se k r(u)ci ofiniê i k s(ve)

t(o)mu p(e)tru da bi mogal' cêlb

biti - i r(e)če p(e)t(a)r' v (i)me o(tb)ca i s(i)na

i d(u)ha s(ve)ta i na tom' časi

pridosta obi ruci ego $\mathrm{v}$ ple

ĉi ego tere bi cel' ki vidêše

to čudo i to znim(e)n(i)e (!) počaše

vêrovati i sl(a)v(i)ti b(og)a i m(o)l(i)t'

gospoû b(ogo)r(odi)cu m(a)riû g(ospo)d(i)nь is(u)h(rbst)' z'v

a deor' (!) n(e)b(e)skoga er(u)s(oli)ma herovi

$\mathrm{m}$ ' serapim' ku čast' dosto

ina e(stb) priêti [mati mo]ê od'govo

riše sili $n(e) b(e) s k i e$ dostoina

e(stb) poiti v n(e)b(e)ska prêstola

$49 v^{b}$

skroviĉa i poide g(ospod)b s množ'

stvomb anĵ(e)lb nose d(u)šu ee

v' e dom' i tu sav'kupi d(u)šu

ee s têlom' i v'znese n(a) n(e)b(e)sk

o ladan'e

Grškovićev zbornik, druga polovica 16. stoljeća,

Cod. VII. 32, ff. 167v-171r, HAZU Zagreb

\section{$167 \mathrm{v}$}

čtenie ot vzneseniê svete marie kako e

vznesena na nebesa nad liki anelskie

Kada b(la)žena diva bogorodica mariê

hoêše plakati na sveti grob sina 
svoga a našega g(ospo)dina $b(o g) a$ is(u)h(rbst)a pr

eklanaûci presveti koleni svoi i molaše

preslatkoga sina svoga g(ospo)dina $b($ og)a da bi û

$\mathrm{g}\left(\right.$ ospo)din $\mathrm{b}\left(\mathrm{og}_{\mathrm{b}}\right)$ vzel ot sega $\mathrm{s}(\mathrm{vê}) \operatorname{ta}$ na vikuvič

ni svet $\mathrm{v}$ cesarastvo nebeskoe A ovi bihu

sveĉali i učinili neverni iûdii da

se ne smi nigdore plakati na grobi sina

božiê ni hoditi na sveti grob nega ot krst(i)ên

\section{8r}

I biše na niko leto drugi dan po vskrišeni g(ospod)ni

$\mathrm{t}\langle\mathrm{e}\rangle \mathrm{r}$ poide $\mathrm{s}(\mathrm{ve})$ ta mariê na sveti grob sina svo

ga preslatkoga $t\langle e\rangle$ r poče molitvu tvoriti poz

iraûci na nebesa k sinu svoemu slatkomu gos

podinu našemu is(u)h(rbst)u $\cdot$ a nei se nebesa otvoriše

gospoi s(ve)toi divi bogorodici marii - I vidi si

na svoga preslatkoga $\cdot$ I tude anel gabrael (!)

preleti $k$ nei i reče veseli se gospoe $b\langle l a\rangle z ̌ e n a ~ d i$

vo marie uslišana e(stb) molitav tvoê na nebe

sih - I hoĉe te sin vzeti na nebesa $\mathrm{v}$ cesaras

tvo nebeskoe $\cdot$ I slišavši diva mariê tu rič

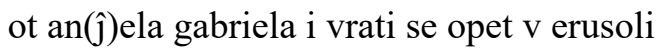

$m$ poêmši tri divice ke noi služahu $t\langle e\rangle$ r im re

če prnesite mi kadilnicu zlatu i držit

e û v ruku I reče gospodine b(ož)e moi isukrste sine

usliši glas moi $\cdot$ I pošli mi $\cdot$ Ivana ap(usto)la t

voga vzlublenoga da videĉi ê nega budu se

veseliti ob nem - I oni vsi ki su se prestav

ili ot sega s(vê)ta $\mathrm{k}$ tebi s(ve)ti ap(usto)li tvoi i ki

su živi na sem s(vê)ti vse mi pošli molim te

sa vsih četirih stran a nadiû se da me hoĉeš

slišati sine moi $\cdot$ I prede $\mathrm{s}(\mathrm{ve}) \mathrm{ti}$ ivan $\mathrm{s}$ patomo

skoga otoka iz efesa grada $\cdot \mathrm{I}$ tu anel reče $\mathrm{k}$ nei

\section{$168 v$}

Radui se b(la)žena s(ve)ta divo b(ogo)r(odi)ce marie usliša na e molitav tvoê hoĉeš poiti ot sega s(vê)ta $\mathrm{s}$ veliku slavu na nebesa s velikus $\mathrm{k}$ svo 
mu sinu slatkomu $\cdot$ A s(ve)ta diva mariê pros

lavi $\mathrm{g}($ ospo)dina $\mathrm{b}(\mathrm{og}) \mathrm{a} \cdot \mathrm{I}$ reče $\mathrm{g}($ ospo)dine $\mathrm{b}(\mathrm{ož}) \mathrm{e}$ is(u)h(rbst)e sine moi

prošu te stvori znameniê mnoga da te se uboe

i ustraše vsi oni ki su te propeli na križi

i vsi oni ki va te ne veruû I kada me vazme

ši pridi množastvo anel tvoih $\mathrm{t}\langle\mathrm{e}\rangle \mathrm{r}$ me vazmi

k sebi ere su se zali židove obeĉali sažg

ati telo moe i s ovu postilû na koi ê ležu ka

da umru I reče ei s(ve)ti ïvan ap(usto)l ne boi se gosp

oe s(ve)ta divo marie $\cdot$ Hote iûdei slišati pri

hodeĉ s(ve)tih ap(usto)l s nebese $\cdot$ Iz drugih stran bra

tiû moû i hote bižati iûdii · I tude duh

s(ve)ti reče vsim ap(usto)lom · Poite v erusolim gra

$d$ na oblak vsedše $k$ b(la)ženoi divi b(ogo)r(odi)ci marii

I tudie pridoše $\mathrm{k}$ nei vsi ap〈usto $\rangle \mathrm{li} \cdot \mathrm{I}$ reče im

$\mathrm{s}(\mathrm{ve}) \mathrm{ti}$ petr $\cdot$ Bratiê moê draga poviite svetoi

marii materi bož(i)ei od kih stran vas e gdo

prišal $\cdot \mathrm{B}($ la)žena diva mariê vsta proti

vsim ap(usto)lom i reče ûre viû da hoĉe priti s $n$

ebes sin moi a vaš učitel $\cdot$ I reče im $\mathrm{s}(\mathrm{ve}) \mathrm{ti}$

\section{9r}

ivan ê vhoêhi k svetomu oltaru na službu bož

iû v crikvi v efesi gradi - I reče mi duh s(ve)ti

Ivane poidi $\mathrm{v}$ erusolim grad na celov $\mathrm{k}$ sve

toi marii materi božei $\cdot$ I oblak svital vz

e me i postavi me simo pred vami - A sveti pe

$\mathrm{t}\langle\mathrm{a}\rangle \mathrm{r}$ reče ê bih $\mathrm{v}$ gradi rimi $\cdot$ I ûtrne poslušahi

a duh $\mathrm{s}(\mathrm{ve})$ ti reče mi poi $\mathrm{v}$ grad erusolim na cel

ov k svetoi marii materi božei hoĉe se prest

aviti k b(og)u od sega sveta $\cdot$ Andrii ap〈usto $\rangle$ l i pi

lip luka simun i ananiê ti iz mrtvih $\mathrm{v}$

staše $\cdot$ I pridoše k svetoi marii materi bož(i)ei

Pavl ap(usto)l reče $\cdot$ ê bihi v gradi piviri i du

h s(ve)ti vze me i postavi me poli vas · Marko

reče $\cdot$ ê bih va aleksandrii gradu i prodikov

ahi e(van)j(eli)e is(u)h(rbsto)vo i duh s(ve)ti vze me i postavi me

posredi vas $\cdot$ A s(ve)ti toma reče ê bih u alvana 
kupca $\mathrm{v}$ polači $\mathrm{v}$ indii $\cdot \mathrm{I}$ duh $\mathrm{s}(\mathrm{ve}) \mathrm{ti}$ vze me i po stavi me simo - êkov reče ê bihi v erusolimi gradu a duh s(ve)ti reče mi vstani i idi simo A s(ve)ti matii reče ê bihi na mori a duh sveti i postavi me posredi vas $\cdot$ A bartolomii reče ê bihi va vitliomi gradu i prodikovahi sl ovo božie a duh s(ve)ti vze me i reče mi idi na celov $\mathrm{k}$ svetoi marii materi božei v erusolim grad

\section{9v}

A gospoê s(ve)ta mariê vzdviže ruci svoi na nebo

I pridoše $\mathrm{k}$ nei vsi aneli herufim i šerafim kad i s(ve)ta mariê mati g(ospod)a našego is(u)h(rbst)a ležaše s lnce i misec i zvezdi · I množastvo s(ve)tih i sv etic stahu pred svetu divu mariû $\cdot$ I pride $\mathrm{k}$ nei mnogo množastvo nedužnih lûdi k presvetoi gospoi i vapiêhu glasom veliem govoreĉe $\cdot \mathrm{S}(\mathrm{ve}) \mathrm{ta}$ mariê pomilui nas nevolnih kako nas ostav laš greduci ot nas $\cdot \mathrm{A} s(\mathrm{ve})$ ta mariê bi milos tiva na grišnike i na nevolne $\cdot$ I tu slipi pr

ozirahu $\cdot$ I tu knasti i nedužni vsi zd $\langle\mathrm{r}\rangle \mathrm{a}$ vi bivahu $\cdot$ I tu se znamenie mnogo činaše okolu s(ve)te gospoe $\cdot$ I tu stahu radosti i pisni i veselie mnogo ot s(ve)tih okolu s(ve)te marie $\cdot$ Iz vidivši to zali i nečisti židove nevern i da se čini veliko veselie · I velika slava božiê ot ap〈usto $\rangle l$ presvetoi marii materi božiei I sveĉa irud i j̧imun $i$ ini hudi židove I zlo vicee uveĉaše i poslaše tisuĉnika $s r$ azboinici na gospoû s(ve)tu mariû i na ove s(ve)te ap〈usto〉le · Idoše $\mathrm{v}$ dom kadi ležaše ova gospoê $\mathrm{s}$ apustoli hoteĉi e êti i sažgati ih · $\mathrm{i}$ bihu sabrali drv mnogo $\cdot$ I kada pridoše židove

\section{0r}

$\mathrm{k}$ domu s(ve)te marie i pride ogan sam is hiže $\cdot \mathrm{I}$ po pali vsih ki bihu prišli pred $\langle\mathrm{d}\rangle$ vari ove gospoe i bi strah velik na vsih po vsem gradu I vsi 
lûdi verni ki se $b(0 g) a$ boêhu $\cdot$ I počeše $b(\operatorname{og})$ a slaviti

i blaženu divu mariû $\cdot$ I mnozi židove to sl

išavše oni ki bihu v gradu obratiše se na ve

ru i spaseni biše $\cdot$ I vsaki ki hoĉe biti spasen

verui v gospoda našego is(u)h(rbst)a i v svetu divu mariû

i v svetu nedilu zač e gospoê v nedilu pozdra

vlena ot an( $(\hat{\jmath})$ ela $\cdot I \mathrm{v}$ nedilû e rodila $\mathrm{g}(\mathrm{ospod})$ a našego

is(u)h(rbst)a I I v nedilû bi vznesena b(la)žena diva bo(go)r(odi)ca

mariê $\cdot$ I v nedilû e vskrišenie g(ospod)ne $\cdot$ I v nedilû e vz

ašstie ego na nebesa $\cdot$ I paki v nedilû hoĉe prit

i suditi živim i mrtvim · I tada reče g(ospo)din

$\mathrm{b}\left(\mathrm{og}_{\mathrm{b}}\right)$ materi svoei ne boi se gospoe i mati moê radui

se i veseli se našla si veliku slavu i ves

elie ko ê imam sa ocem moim · Ke slave nigdor

ispovidati ne more $\cdot \mathrm{I}$ duša tvoê poide $\mathrm{v}$ svitla

skroviĉa kadi e mir i veselie mnogo I tada reče

gospoê s(ve)ta mariê g(ospo)d(i)nu b(og)u sinu moi predragi

položi ruku desnuû tvoû na me i blagoslovi me

A on ei poda ruku A ona gospoê držicii (!) častni

ruci sina svoga reče sinu moi predragi klanaû se

\section{0v}

desnici tvoei presvetoi i celova û - I reče g(ospodi)ne b(ož)e sinu moi primi dušu moû $g($ ospo)dine b(ož)e ošĉe te prošu

budi milostiv vsakomu krstêninu ki ime $\mathrm{t}$

voe hvale i moi post poste zač sam te rodila

sinu moi uprosi mi se $\cdot$ I reče ei g(ospo $) d(i) n ~ b\left(o g g b_{b}\right)$ gospoe sv

eta marie vsaki čl(ovê)k ki spomenue ime tvoe it

ebi čast čine tvoi post poste nih duša ne

pogine do konca $\cdot \mathrm{I}$ reče $\mathrm{g}(\mathrm{ospod})$ in $\mathrm{b}\left(\mathrm{og}_{\mathrm{b}}\right)$ svetomu petru $\mathrm{pr}$

istupi simo bliže hoĉe poiti s(ve)ta bogorodi

ca diva mariê na nebo s duhom svetim počni

peti pisan · A s(ve)ti petr poče peti $\cdot a($ lelu)ê $\cdot i$ vse

sili nebeskie vzapiše glasom velikim $\cdot a(l e l u) e ̂$

I prosveti lice $\mathrm{b}(\mathrm{la}) \bar{z}(\mathrm{e})$ ne divi marie $\cdot \tilde{z} \cdot(=7) \mathrm{krat}$

veĉe nere salnce sega svita $t\langle e\rangle$ r poda ruci

svoi i blagoslovi ap(usto)li t $\langle\mathrm{e}\rangle \mathrm{r}$ vzdahnu $\cdot$ I gos

podin $b\left(\mathrm{og}_{b}\right)$ prostri ruci svoi presveti $\mathrm{i}$ vze $\mathrm{pr}$ 
esvetu i prečistu dušu b(la)žene divi b(ogo)r(odi)ce ma rie matere svoe I kada izide presveta duša is tela nee tada on grad bož(i)i s(ve)ti erusolim isplni se blagouhaniê $\cdot A$ go(spo)din $b\left(o_{b}\right)$ ponese $d u$ šu presvetuû ne s telom duhom s(ve)tim A sil i nebeskie počeše peti glasom velikim b(la)žena

\section{1r}

ti esi v ženah $\cdot$ A s(ve)ti počeše peti vzamše telo $\mathrm{s}(\mathrm{ve})$ te gospoe $\cdot$ I položiše e na odar i ponesoše e vsedše na $\cdot \tilde{b} \tilde{i} \cdot(=12)$ oblaka svitla $\cdot$ I tada edan židovin imenem ofiên poteče i poče razmetati posti lû s(ve)te marie i na tom časi mu otpadosta obi ruci is pleĉu $i$ tako se poče valati ofiên pre $\mathrm{z}$ ruku - I moliti se poče s(ve)toi marii i s(ve)tomu petru ap(usto)lu da bi mogal cel biti · I reče s(ve)ti petr da iscelieši ga $\cdot$ Va ime oca i sina i duha $\mathrm{s}(\mathrm{ve})$ ta amen - I tudie na tom času bi cel kako pr iê $\cdot$ I vsi lûdi ki vidiše to čudo počeše ver ovati v gospoda našego is(u)h(rbst)a i v svetu di vu mariû i v svetu nedilû $\cdot$ I tako e imiti v sakomu krstêninu pravu veru kako su û imeli vsi pravadnici čineĉi zapovid božiû kaû

ĉi se grihov svoih da e pomilûe $g(\mathrm{ospo}) \operatorname{din} \mathrm{b}\left(\mathrm{og}_{\mathrm{b}}\right)$ kako e po miloval vse pravadniki - I tako vznesena est na nebo sveta bogorodica mariê koi budi čast sa ocem i sinom i duhom s(ve)tim va veki vik Amen 


\section{IZVORI}

CFat = Fatevićev zbornik duhovnog štiva, 1617., HAZU, Zagreb, Cod. IV. a 124 [IV. A 141], f. 1r-1v i ff. 18v-22v: Na Vznesene Divice Marie; izd. FZ 2016: $177-$ 178, 212-220.

CGř̌ = Grškovićev zbornik, druga polovica 16. stoljeća, HAZU, Zagreb, Cod. VII. 32, ff. 167v-171r: čtenie ot vzneseniê svete deve marie; izdanje u prilogu ovoga rada.

CVar = Codex Varia Variorum 39 (914) Franjevačke biblioteke u Dubrovniku, 17. stoljeće, str. 1-40 : Nadan vfisciafchia. D. M. nanebessa; izd. KARÁSEK 1913: $1-15$.

CVinod $=$ Vinodolski zbornik, prva polovica 15. stoljeća, HAZU, Zagreb, Cod. III. a 15 (Kukuljevićeva zbirka, rukopis br. 351), ff. 48ra $-49 v^{b}$ : izdanje u prilogu ovoga rada.

FgTrans = Pazinski fragmenti, početak 14. stoljeća, fragm. glag. 90d-e-f, HAZU, Zagreb; izd: MIHALJEVIĆ; VINCE 2012: 132-138.

\section{LITERATURA}

ARRAS, V. 1973. De Transitu Mariae Aethiopice I-II. Louvain: Secrétariat du Corpus scriptorum Christianorum Orientalium.

BADURINA STIPČEVIĆ, V. (prir.) 2013. Hrvatska srednjovjekovna proza I. Legende $i$ romani. Zagreb: Matica hrvatska, 11-27.

BERGER, F. X. 1805. Sancti Ioannis, theologi et evangelistae, in dormitionem sanctissimae Dieparae. J. Ch. von Aretin (ed.). Beyträge zur Geschichte und Literatur, vorzüglich aus den Schätzen der pfalzbaierischen Centralbibliothek zu München 5, 629-663.

BRATULIĆ, J. 1996. Dubrovačke legende, u: Dubrovačke legende. Josip Karásek (ur.). Zagreb: Dora Krupićeva, 1996. [pretisak izdanja: Praha: Leschinger, 1913.], 195-199.

BUNČUGA, B. Predgovor, u: FZ 2016: 5.

DAMJANOVIĆ, S. 1984. Tragom jezika hrvatskih glagoljaša. Zagreb: Sveučilišna naklada Liber.

DAMJANOVIĆ, S. (prir.).1998. Hrvatska srednjovjekovna književnost. Vinkovci: Riječ, 35-37.

DAMJANOVIĆ, S. 1995. Glagolitica kajkaviana. S. Damjanović. Jazik otačaski. Zagreb: Matica hrvatska, 63-81.

DAMJANOVIĆ, S. 2000. Filološki razgovori. Zagreb: Hrvatska sveučilišna naklada, 29-43.

DAMJANOVIĆ, S. 2008. Jezik hrvatskih glagoljaša. Zagreb: Matica hrvatska, 24-128.

DAMJANOVIĆ, S. 2009. Staroslavenski i starohrvatski u hrvatskim srednjovjekovnim spomenicima, u: S. Damjanović (ur.), Povijest hrvatskoga jezika. 1. knjiga: Srednji vijek. Zagreb: Društvo za promicanje hrvatske kulture i znanosti Croatica, 351-403.

DAMJANOVIĆ, S. 2014. Novi filološki prinosi. Zagreb: Matica hrvatska, 28-35.

DÜRRIGL, M.-A. (prir.). 2013. Hrvatska srednjovjekovna proza II. Apokrifi, vizije, prenja, Marijini mirakuli. Zagreb: Matica hrvatska, 11-34, 135-138. 
DÜRRIGL, M.-A. 2017. Pouka o ovozemaljskom čistilištu iz Fatevićeva zbornika. Slovo 67: $23-43$.

FZ 2016. Fatevićev zbornik duhovnog štiva 1617. B. Bančuga, J. Faričić, P. Kero (ur.). Riznica glagoljaške kulture i hrvatske pismenosti otoka Rave, sv.3. Fatevićev zbornik duhovnog štiva 1617. Zadar: Stalna izložba crkvene umjetnosti - Sveučilište u Zadru, 212-220.

FRANOV-ŽIVKOVIĆ, G. 2016. Fatevićev zbornik duhovnog štiva, u: FZ: 7-12.

GALIĆ, J. 2017. Ravsko glagoljsko četveroknjižje. Slovo 67: 199-208.

GALIĆ, J. 2018. Fonološke osobitosti Zbornika u Berčićevoj zbirci br. 5 i Fatevićeva zbornika duhovnoga štiva. Slovo 68: 99-169.

GRABAR, B. 1967. Apokrifna Djela apostolska u hrvatskoglagoljskoj literaturi. Radovi Staroslavenskog instituta 6: 109-208.

GRABAR, B. 1970. Apokrifi u hrvatskoj srednjovjekovnoj književnosti. Croatica 1: 15-28.

GRABAR, B. 1978. Pazinski fragmenti. Istra 16: 21-26.

GRABAR, B. 1981. Les fragments glagolitiques de Pazin. Cyrilomethodianum V: 130-134.

HAIBACH-REINISCH, M. (ed.). 1962. Ein neuer 'Transitus Mariae' des Pseudo-Melito. Roma: Pontificia Academia Mariana Internationalis.

HCSL 2014. = S. Gadžijeva; A. Kovačević; M. Mihaljević; S. Požar; J. Reinhart; M. Šimić; J. Vince. Hrvatski crkvenoslavenski jezik. M. Mihaljević (prir.). Zagreb: Hrvatska sveučilišna naklada - Staroslavenski institut.

HERCIGONJA, E. 1975. Srednjovjekovna književnost. Povijest hrvatske književnosti, knj. 2. Zagreb: Liber - Mladost.

HERCIGONJA, E. 2004. Na temeljima hrvatske književne kulture. Filološkomedievističke rasprave. Zagreb: Matica hrvatska: 53-111, 234-280.

HERCIGONJA, E. 1983. Kajkavski elementi u jeziku glagoljaške književnosti 15. i 16.stoljeća. Nad iskonom hrvatske knjige. Rasprave o hrvatskom srednjovjekovlju. Zagreb: Sveučilišna naklada Liber, 303-385.

HERCIGONJA, E. 2006. Tropismena i trojezična kultura hrvatskoga srednjovjekovlja [2. izdanje]. Zagreb: Matica hrvatska.

HERCIGONJA, E. 2009. Tisućljeće hrvatskoga glagoljaštva. Zagreb: Hrvatska sveučilišna naklada.

KARÁSEK, J. 1913. Dubrovačke legende. Praha: Leschinger, 1-15. [pretisak: Zagreb: Dora Krupićeva, 1996.]

KOMBOL, M. 1945. Poviest hrvatske književnosti do narodnog preporoda. Zagreb: Matica hrvatska.

MALIĆ, D. 1992. Crkvenoslavenska jezična tradicija u hrvatskim latiničkim rukopisima 14. stoljeća. Rasprave ZHJ 18: 99-117.

MALIĆ, D. 1997. Žića svetih otaca. Zagreb: Matica hrvatska, Institut za hrvatski jezik, 456-483.

MIHALJEVIĆ, M.; J. VINCE. 2012. Jezik hrvatskoglagoljskih Pazinskih fragmenata. Zagreb: Hrvatska sveučilišna naklada, Državni arhiv u Pazinu, Staroslavenski institut.

MIHALJEVIĆ, M. 2018. Jezik najstarijih hrvatskoglagoljskih rukopisa. Zagreb: Hrvatska sveučilišna naklada, Staroslavenski institut.

MILČETIĆ, I. 1911. Hrvatska glagolska bibliografija. I. dio: opis rukopisa. Starine 33, Zagreb: JAZU. 
NAZOR, A. 2008. »Ja slovo znajući govorim ... « Knjige o hrvatskoj glagoljici. Zagreb: Erazmus naklada: 59-60.

NAZOR, A. 1978. Zagreb riznica glagoljice. Katalog izložbe. Zagreb: Nacionalna i sveučilišna biblioteka.

MIKECIN, M. 2018. Apokrif Usnuće Bogorodice u hrvatskoglagoljskoj književnosti (I). Usporedba teksta iz Pazinskih fragmenata s grčkim izvornikom i najstarijim slavenskim tekstovima. Slovo 68: 227-288.

PETROVIĆ, I. 1977. Marijini mirakuli u hrvatskim glagoljskim zbirkama i njihovi evropski izvori. Radovi Staroslavenskog instituta 8: 24-26, 40-41.

PETROVIĆ, I. 1984. Hagiografsko-legendarna književnost hrvatskog srednjovjekovlja i senjski »Marijini mirakuli« : izvori, žanrovske, tematske i tipološke karakteristike. Slovo 34: 181-201.

PETROVIĆ, I. 1998. Fatević, Mikula, pisar glagoljaš (druga pol. XVI. st. - prva pol. XVII. st.). Hrvatski biografski leksikon, sv. 4. Zagreb: Leksikografski zavod Miroslav Krleža, 143.

PG 1894 = Patrologia Graeca 5. 1894. Melito Sardium in Asia Episcopus, 1231-1240. J. P. Migne (ed.). Paris: Garnier Fratres.

RADOŠEVIĆ, A. 2012. Korizmene propovijedi u Fatevićevu zborniku - prilog rekonstrukciji glagoljskoga Korizmenjaka. Slovo 62: 101-210.

REINHART. J. 2010. Kombinacija dvaju mirakula u hrvatskoglagoljskom rukopisu (Grškovićev zbornik, HAZU VII 32). Slovo 60: 669-686.

STROHAL, R. 1915. Hrvatska glagolska knjiga. Zagreb: Tiskara Merkur.

STROHAL, R. 1916. Cvêt vsake mudrosti. Najstarije hrvatsko umjetno sačuvano književno djelo iz 14. vijeka. Zagreb: Tisak C. Albrechta.

STROHAL, R. 1917. Stare hrvatske apokrifne priče i legende. Bjelovar: Weiss, 36-39.

ŠABIĆ, M. 2010. Suradnja Josefa Karáseka i Milivoja Šrepela. Kroatologija 1: 281-299.

ŠTEFANIĆ, V. I SUR. 1969. Hrvatska književnost srednjeg vijeka. Zagreb: Matica hrvatska - Zora, 149-153.

ŠTEFANIĆ, V. 1970. Glagoljski rukopisi Jugoslavenske akademije. II. dio: zbornici različitog sadržaja, regule i statuti, registri, varia, indeksi, album slika. Zagreb: JAZU.

TISCHENDORF, von C. 1866. Apocalypses apocryphae Mosis, Esdrae, Pauli, Johannis, item Mariae dormitio. Leipzig: Mendelssohn, 95-112, 124-136; pretisak Hildesheim: Olms, 1966.

TURKALJ, L. 2008. Život Adama i Eve u Žgombićevu i Fatevićevu zborniku. Slovo 5657: 579-593.

VELČIĆ, F. 2002. GRŠKOVIĆ, Ivan, kulturni povjesničar (Vrbnik, 2. XII. 1883 - Krk, 16. VII. 1967). Hrvatski biografski leksikon $5(G n-H)$. Zagreb: Leksikografski zavod »Miroslav Krleža«, 244.

VIGATO, I. Jezične osobitosti ravskih glagoljskih rukopisa Madrikule sv. Roka i Kvaterana iz 17. i 18. stoljeća, u: FZ 2016: 29-39.

VUČKOVIĆ, A. 2017. Srednjovjekovni itinerar po Svetoj zemlji iz Vinodolskoga zbornika. Slovo 67: 45-90. 
Sum mary

\section{Milica Mikecin}

\section{APOCRYPHON TRANSITUS MARIAE IN CROATIAN-GLAGOLITIC LITERA- TURE (II). A COMPARATIVE LINGUISTIC AND TEXTOLOGICAL ANALYSIS OF THE MISCELLANY TEXTS}

Several non-liturgical texts in Croatian medieval literature contain the apocryphon on Virgin Mary's death and assumption. In some of them it is the transcript of the rewritten Croatian-Church Slavonic translation of the Greek text of Pseudo-John the Apostle and Evangelist, which belongs to the Bethlehem manuscript tradition of the apocryphon (Vinodol Miscellany, $15^{\text {th }}$ century, and Grškovic Miscellany, $16^{\text {th }}$ century), while the others contain the transcript of the rewritten Croatian-Church Slavonic translation of the Latin translation of the Greek text of Pseudo-Meliton, which belongs to the Palm tradition (Fatević Miscellany, 1617, and Latin Codex Varia Variorum 39, $17^{\text {th }}$ century). A comparative linguistic and textological analysis of the oldest preserved Croatian Glagolitic text of the Bethlehem tradition from the Pazin Fragments ( $14^{\text {th }}$ century) and the text from the Vinodol Miscellany in relationship to the Greek original, further a comparative analysis of the text from the Vinodol Miscellany and the cognate text from the Gršković Miscellany, and finally a comparative analysis of the texts from the Fatevic Miscellany and the Codex Varia Variorum 39 show the main features of the language of all four miscellany texts on all linguistic levels regarding the impact of the Old Church Slavonic linguistic elements and the elements of the Croatian vernacular. Using the example of the apocryphon of Mary's assumption in Croatian medieval Glagolitic and Latin literature, the paper explores the historical development of the language from the Croatian Church Slavonic, older and newer Croatian-Church Slavonic to the Croatian vernacular language with Old Church Slavonic elements. The paper also provides a transliterated edition of the texts from the Vinodol Miscellany and Gršković Miscellany.

Keywords: Apocryphon on Mary's death, Pazin Fragments, Vinodol Miscellany, Gršković Miscellany, Fatević Miscellany, Codex Varia Variorum, Croatian Glagolitic Literature, Croatian Church Slavonic language, Croatian-Church Slavonic language, Chakavian language, comparative linguistic and textological analysis

Milica Mikecin

Zagreb (Hrvatska)

milamikecin@yahoo.com 